\title{
Site U1350'
}

\author{
Expedition 324 Scientists $^{2}$
}

\section{Chapter contents}

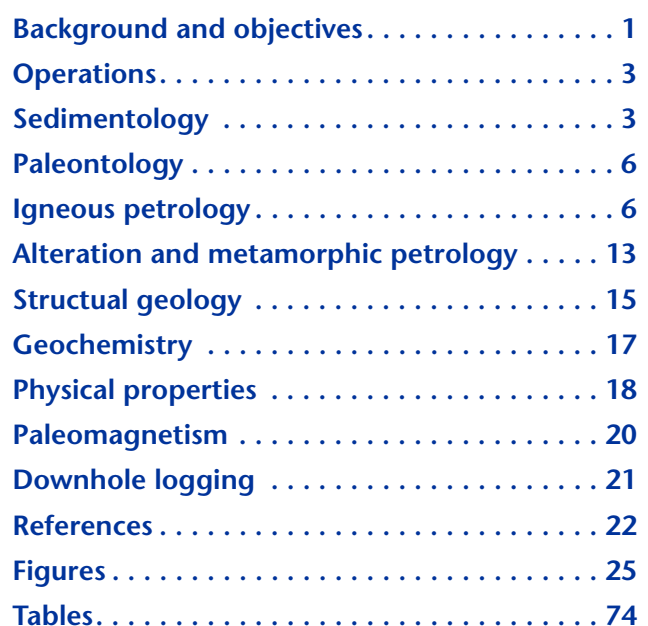

${ }^{1}$ Expedition 324 Scientists, 2010. Site U1350. In Sager, W.W., Sano, T., Geldmacher, J., and the Expedition 324 Scientists, Proc. IODP, 324: Tokyo (Integrated Ocean Drilling Program Management International, Inc.).

doi:10.2204/iodp.proc.324.107.2010

'Expedition 324 Scientists' addresses.

\section{Background and objectives}

\section{Background}

Integrated Ocean Drilling Program Site U1350 (proposed Site SRCH-4) on Ori Massif was the fifth and last site completed during Expedition 324. This site is on the lower east flank of Ori Massif (Fig. F1), where it was intended as a comparison site to the summit of Ori Massif (Site U1349) and sites to the south on Tamu Massif (Ocean Drilling Program [ODP] Site 1213 and Sites U1348 and U1349) and to the north on Shirshov Massif (Site U1346). Only one hole, U1350A, was cored at the site, reaching a total depth of 315.8 meters below seafloor (mbsf). According to the initial expedition plan, Site U1350 was an alternate site and proposed Site SRSH-8 was planned as the last place to drill during Expedition 324. Site U1350 was substituted because the scientific party decided that it was more important to recover cores from the flank of Ori Massif than to drill another site on Tamu Massif close to Site 1213, where igneous rocks were cored during Leg 198 (Shipboard Scientific Party, 2002). It was felt that the lower flank location of Site U1350 would be a good spot to core fresh igneous rocks in contrast to the highly altered rocks cored at Site U1349 on the Ori Massif summit. Because it was the last site to be explored during Expedition 324, Site U1350 was cored until time expired. Nevertheless, a better than average rate of penetration allowed the deepest penetration into igneous basement $(172.7 \mathrm{~m})$ of any Expedition 324 site.

Ori Massif is the second largest volcanic construct within Shatsky Rise, with a volume of $\sim 0.7 \times 10^{6} \mathrm{~km}^{3}$ (Sager et al., 1999). Like Tamu Massif, it may have formed over a geologically short period of time $(<1$ m.y.) with a high effusion rate, but the actual age and duration are unknown. Because Ori Massif is separated from Tamu Massif by a narrow, rectangular, faulted basin ("Helios Basin;" see Fig. F2 in the "Expedition 324 summary" chapter), speculation that Ori and Tamu massifs formed together and later rifted (Sager et al., 1999; Nakanishi et al., 1999) has been raised. In the context of the plume head hypothesis, Ori Massif appears to represent the eruptions during a transition in volume from plume head (Tamu Massif) to plume tail (Papanin Ridge).

Magnetic lineations surrounding Ori Massif imply that it formed on lithosphere of earliest Cretaceous age. Anomaly M16 brackets the southeast flank, whereas Anomaly M14 crosses the northwest flank (Nakanishi et al., 1999) (Fig. F3 in the "Expedition 324 sum- 
mary" chapter). According to the geomagnetic polarity timescale (Ogg et al., 2008), the age of the lithosphere at Ori Massif is $\sim 142-140 \mathrm{Ma}$, which may also be the age for Ori Massif if it formed nearly synchronously with the lithosphere, as implied by isostatic compensation (Sandwell and McKenzie, 1989). The northeast and southwest flanks of Ori Massif appear to be bounded by fracture zones (Nakanishi et al., 1999) and this bracketing by spreading ridges and fracture zones, which are orthogonal, may be the reason that the massif appears subcircular or nearly square in plan view (Sager et al., 1999).

Like Tamu Massif, Ori Massif has the appearance of a large central volcano with low flank slopes (Sager et al., 1999). Too few bathymetry data exist to say which flanks of this edifice are smooth and which are faulted, although the shape of the southern margin implies rifting, whereas the smooth nature of the eastern flank suggests a volcanic slope (Sager et al., 1999; Klaus and Sager, 2002). As with other Shatsky Rise massifs, the rise top is covered with pelagic sediment reaching a maximum thicknesses of 600-700 $\mathrm{m}$ on existing seismic profiles (Sager et al., 1999; Klaus and Sager, 2002). Ori Massif has volcanic summit ridges, just like Tamu Massif, but all are buried or mostly so and thus are not as prominent as the large ridge (Toronto Ridge) (Sager et al., 1999) atop Tamu Massif. The origin of these ridges is not known, although they appear to be volcanic constructs and not fault-bounded ridges (i.e., horsts). Site U1349 was drilled on one of these ridges, recovering igneous rocks that appear to have formed in a subaerial or shallow-water environment and perhaps represent a late stage of Ori Massif formation. In contrast, the smooth, gently sloping eastern flank acoustic basement, where Site U1350 is located, probably represents lava flows erupted during the main shieldbuilding phase of Ori Massif eruptions. From predrilling interpretation of the site survey seismic reflection profile (Fig. F2), we expected to encounter $157 \mathrm{~m}$ of pelagic sediments overlying igneous basement consisting of basaltic lava flows.

\section{Scientific objectives}

Sampling the flank of Ori Massif was considered an important objective because this volcano is a major edifice within Shatsky Rise. Furthermore, Site U1350 is near the center of a transect of sites along the axis of Shatsky Rise planned to yield age and geochemical trends within the plateau, so coring relatively fresh basalt from Ori Massif was a high priority. As with most Expedition 324 sites, the operational goal for the site was to drill through the sediment overburden, core the oldest sediment overlying igneous basement, and core as deeply into the igneous formation as possible during the time allowed.

Scientific objectives of all Expedition 324 sites are similar (for more details and rationale, see the "Expedition 324 summary" chapter). Coring of igneous rock was planned to determine the age of igneous basement so that the age progression and duration of volcanism at Shatsky Rise could be constrained. A critical objective at Site U1350, and indeed all Expedition 324 sites, was to core enough igneous rock of suitable freshness and composition to allow at least one reliable radiometric date to be established. Igneous rocks are critical to geochemical and isotopic studies whose goals are to establish the elemental compositions, variations in compositions, and the isotopic characteristics of the rocks. Such data are crucial for determining the source of magma, inferring its temperature and depth of melting and crystallization, and deducing the degree of partial melting, as well as tracking its evolution with time. Operationally, this meant that the goal at Site U1350 was to core a representative suite of igneous units that was fresh enough to provide reliable geochemical and isotopic measurements.

Expedition 324 also sought to constrain the evolution of Shatsky Rise by collecting samples for a host of nongeochemical studies focusing on varied aspects of rise geology. Physical volcanologists, structural geologists, and logging geophysicists will use cores to infer the eruption style, igneous products, and physical structure of Shatsky Rise. Given its size and inferred eruption rate, Ori Massif is likely to be an example of an unusual volcanic construct whose development is poorly understood. Shatsky Rise core samples will also be used to study the submarine alteration of igneous rock and its effect on other analyses. Studies of sediments overlying igneous basement are planned to better understand the paleontological age of Shatsky Rise sediments and the processes and rates of Cretaceous sedimentation atop the rise volcanoes. Although few sediment samples were cored from Site U1350, sedimentologists will carefully examine the sparse sediments that were cored. Sediment types and paleontological environment data will hopefully indicate the paleodepths of sediment deposition, information that is important for understanding the eruption and subsidence history of the volcanic edifices. Paleomagnetic study of the samples recovered during Expedition 324 seeks to determine the magnetic polarity of basement for comparison with surrounding magnetic lineations and the geomagnetic polarity timescale, as well as the paleolatitude of the rise and its plate tectonic drift. Physical properties of Shatsky Rise core samples 
will be measured to better understand the nature of the rocks that make up the rise and to constrain fundamental physical properties that affect geophysical imaging and remote sensing. Because Site U1350 igneous rocks are relatively fresh, physical property measurements will be important for determining rock properties that can be used for geophysical data interpretation.

\section{Operations}

Times in this chapter are given in local ship time. During transit to Site U1346, shipboard clocks were advanced $1 \mathrm{~h}$, resetting local ship time to Sydney Standard Time (Universal Time Coordinated $+10 \mathrm{~h}$ ). No further adjustments to the clock were made during the expedition.

The $53 \mathrm{nmi}$ transit from Site U1349 to Site U1350 proceeded at an average speed of $10.6 \mathrm{kt}$. At $0115 \mathrm{~h}$ on 13 October 2009, the vessel was positioned on the new drill site. The driller tagged the seafloor at $4067.0 \mathrm{~m}$ drilling depth below rig floor (DRF) (4055.9 meters below sea level [mbsl]) (Table T1) at $1030 \mathrm{~h}$. This was $12 \mathrm{~m}$ shallower than the corrected precision depth recorder depth of $4079.0 \mathrm{~m}$ DRF. Hole U1350A was spudded with a wash barrel in place and drilled to $104.6 \mathrm{~m}$ drilling depth below seafloor (DSF), where rotary coring was initiated at $1115 \mathrm{~h}$. The sediment portion $(48.0 \mathrm{~m})$ of the hole was cored with the usual poor recovery $(1.6 \%)$ because of soft ooze and chalk sediments mixed with chert layers. Igneous basement was reached with Core 324-U1350A-6R at $143.1 \mathrm{~m}$ DSF, which was slightly shallower than the expected depth of $\sim 157$ mbsf, calculated from the site survey seismic data.

Rotary coring deepened the hole to a final depth of $315.8 \mathrm{~m}$ DSF at $2015 \mathrm{~h}$ on 18 October when operating time expired. The final depth corresponds to a total penetration of $172.7 \mathrm{~m}$ in basement, which was cored with an average recovery of $43.2 \%$ and an average rate of penetration (ROP) of $2.0 \mathrm{~m} / \mathrm{h}$. A total interval of $211.2 \mathrm{~m}$ was cored with an average recovery of $35.6 \%$ at an average ROP of $3.5 \mathrm{~m} / \mathrm{h}$. When coring was halted, the bit had accumulated 91.2 rotating hours and was still viable.

In preparation for logging, the hole was flushed with a $50 \mathrm{bbl}$ mud sweep followed by a wiper trip up to 84 $\mathrm{m}$ DSF and back down to $316 \mathrm{~m}$ DSF. Following another $50 \mathrm{bbl}$ sweep, the bit was released with the rotary shifting tool and the hole was displaced with 90 bbl of $10.5 \mathrm{ppg}$ heavy mud. The pipe was then pulled back in the hole with the end of pipe placed at the logging depth of 117 m DSF (4184 m DRF).
The first of potentially two logging runs was attempted with the triple combination (triple combo) tool string, which was deployed at $0640 \mathrm{~h}$ on 19 October and lowered at a speed of $2200 \mathrm{~m} / \mathrm{h}$ to $3600 \mathrm{~m}$ DRF. At this depth, the head tension decreased dramatically and the cable speed was reduced to $~ 90$ $120 \mathrm{~m} / \mathrm{h}$ to avoid potential damage to the wireline. The slow progress required pumping pressure down the drill pipe to aid the descent. After making very slow progress to $4000 \mathrm{~m}$ DRF, it was decided to pull out of the hole to check the tool string and cable for damage. With the tool string on the rig floor it was decided to pump down high volumes of water through the pipe to remove any potential obstruction. The tool string was deployed a second time with similar results, reaching $4122 \mathrm{~m}$ DRF. As time was expiring, the weather was progressively deteriorating (initial ship heave conditions of $\sim 2 \mathrm{~m}$ changed to $\sim 4 \mathrm{~m}$ with wind gusts of up to $56 \mathrm{kt}$ ). Without knowing the cause of the low-tension problem, it was decided to terminate logging operations. The tool was recovered at $2330 \mathrm{~h}$, and after the logging equipment was rigged down the drill string was pulled out of the hole, clearing the seafloor at $0125 \mathrm{~h}$ on 20 October. After securing the drilling equipment and hydrophones and recovering the beacon, the vessel departed for its transit to Townsville at $1245 \mathrm{~h}$ on 20 October. The total time at Site U1350 was 7.5 days (Fig. F3).

\section{Sedimentology}

One hole was drilled at Site U1350 on the flank of Ori Massif, Shatsky Rise (water depth $=4056 \mathrm{mbsl}$ ). Only one purely sedimentary unit was defined at this site (stratigraphic Unit I) that spanned Cores 324-U1350A-1W through 6R. Although it is likely Unit I is composed of both chert and calcareous ooze or chalk, only chert (predominantly black and, less commonly, red-brown) with minor amounts of porcellanite coating was recovered. Well-preserved radiolarians, concentrated around relict burrow features, are common in Unit I cherts. Igneous basement was reached in Core 6R at 143.1 mbsf, but additional sediments interbedded with the basaltic strata in stratigraphic Units II and IV were encountered. These sediments, predominantly fine-grained carbonates with radiolarians and volcaniclastics, contained varying quantities of bivalve and brachiopod fossils. Sedimentary interbeds were especially prevalent in Unit IV (Cores 25R through 26R), where small pillow basalts appear to have intruded carbonate-rich ooze prior to lithification. 


\section{Unit descriptions}

The stratigraphy at Site U1350, including basaltic basement divisions and sedimentary interbeds, is shown in Figure F4.

- Unit I: chert and porcellanite (104.6-143.1 mbsf).

- Unit II: igneous unit divided into Subunits IIa-IIc.

- Subunit IIa: massive basalt (large inflation units) with minor sedimentary interbeds (143.1-219.9 mbsf).

- Subunit IIb: massive-pillow basalt transition with minor sedimentary interbeds (219.9-240.5 mbsf).

- Subunit IIc: small pillow basalts with rare sedimentary interbeds (240.5-290.4 mbsf).

- Unit III: hyaloclastite and brecciated basalt (290.4-296.7 mbsf); no sedimentary beds.

- Unit IV: plagioclase-phyric pillow basalts with intercalated limestone (296.7-316.0 mbsf).

\section{Unit I}

Interval: 324-U1350A-1W through 6R

Depth: 104.6-143.1 mbsf

The recovery of Unit I at Site U1350 was poor and restricted to small isolated pieces of chert in Cores 324U1350A-1W and 3R through 6R. No material was recovered in Core 2R. Black cherts are the predominant lithology; however, some reddish brown chert is present at the top of Core 1W. Many of the pieces contain relict bedding and traces of bioturbation, preserved as gray porcellanite patches (Fig. F5). Pyrite is occasionally seen replacing burrow structures in the black chert but is absent in the red. Many chert pieces in this unit are coated by thin (1-2 mm) pale brownish white porcellanite. Radiolarian fossils are abundant, well preserved in many of the cherts, and often concentrated around relict burrow structures.

\section{Sedimentary interbeds with igneous basement (Units II- IV)}

Several small sedimentary layers were recovered interbedded with the igneous strata at Site U1350 but were not extensive enough to warrant unit divisions of their own. See Figure F4 for location of these interbeds, which are denoted by yellow lines in the diagram.

\section{Unit II}

Interval: 324-U1350A-6R through 24R

Depth: 143.1-290.4 mbsf

\section{Subunit IIa}

Subunit IIa is predominantly composed of massive flow basalts (see "Igneous petrology"); however, small sedimentary interbeds were found in Cores 324-U1350A-8R, 9R, 14R, and 15R. Many of these interbeds have blackened outer rims and display a waxy texture. Sediments are predominantly limestone with altered volcaniclastics. Some of the volcaniclastic grains altered to clay minerals, which are more susceptible to weathering and often leave small cavities within the limestone matrix. Pyrite is occasionally associated with the weathered volcanic clasts but is not present elsewhere in the limestone. Pale blue zeolitic minerals were observed in both hand specimen (Fig. F6) and thin section. Sedimentary rocks in this subunit often contain secondary calcite as cement or in the form of thin veins. The few radiolarians observed in thin section were nearly completely replaced by calcite and poorly preserved.

One small rock fragment $(1.5 \mathrm{~cm} \times 2 \mathrm{~cm})$ in Core 324-U1350A-9R contained two different lithologies distinguished by a sharp color boundary and minor textural change (Fig. F7). Approximately $60 \%$ of the rock is volcaniclastic silty sandstone and the remainder volcaniclastic limestone.

\section{Subunit IIb}

This subunit represents the transitional phase between the aphyric pillow succession in Subunit IIc and the massive flows of Subunit IIa and spans Cores 324-U1350A-17R through 19R (see "Igneous petrology"). Sedimentary interbeds present in Cores $17 \mathrm{R}$ and 18R consist of greenish gray volcaniclastic limestones and dark gray calcite-cemented volcaniclastics. Some of the rocks in this subunit contain volcanic glass shards, and alteration is apparent and likely from contact with hot basaltic material as it was emplaced nearby.

Intervals 324-U1350A-17R-2, 120-124 cm, and 18R$1,11.5-20.5 \mathrm{~cm}$, contain brownish gray altered volcaniclastic limestones composed of calcite-cemented palagonitized glass shards. These rocks are friable, contain clay, and can be easily scratched with a fingernail.

\section{Subunit IIc}

Few sedimentary beds were recovered from Subunit IIc, which is an aphyric pillow basalt succession (see "Igneous petrology"). Gray volcaniclastic limestones found in Cores 324-U1350A-20R and 21R have blackened and cracked margins. Thin sections reveal that these limestones are primarily micritic and contain radiolarians that have been replaced by calcite. Preservation of the microfossils is only poor 
to moderate; however, delicate netlike structures are still visible in some specimens. (Fig. F8).

It is important to note that sedimentary interbeds were not recovered from the lower part of Subunit IIc ( 265-290 mbsf).

\section{Unit III}

Interval: 324-U1350A-24R-3 through 24R-4

Depth: 290.4-296.7 mbsf

Unit III is predominantly composed of hyaloclastite and brecciated basalt and spans the short interval between the base of Section 324-U1350A-24R-3 and the end of Section 24R-4 (see "Igneous petrology"). No sedimentary interbeds were recovered from this unit.

\section{Unit IV}

Interval: 324-U1350A-25R through 26R

Depth: 296.7-315.8 mbsf

Many calcareous sedimentary beds were recovered intercalated with the plagioclase phyric pillow basalts in Unit IV (see "Igneous petrology"). These sediments are exclusively limestone with one exception. Volcaniclastic sandstone composed of dark gray, laminated, altered hyaloclastite was recovered spanning 126-142 cm in Section 324-U1350A-25R-1. The rock appears to be composed of grains of different sizes; however, in thin section it is apparent that the glass shards in the "fine-grained" portion are more compacted and have less pore space with calcitic cement infilling than those in the "coarsegrained" portion (Fig. F9). This $16 \mathrm{~cm}$ long piece shows signs of postdepositional brittle deformation in the form of small en echelon microfaults (Fig. F10).

The remainder of the sedimentary material recovered from Unit IV is micritic limestones, often with a volcaniclastic component. Many of the limestones have blackened baked margins and slightly waxy textures where they are in contact with the pillow basalts. The pillows themselves often have black glassy rims and fractured margins, sometimes infilled with sediment. Poorly to moderately preserved radiolarian fossils and radiolarian "ghosts" are common in the limestones in this unit. Most have been replaced by calcite or clay but with their delicate structures preserved; a few siliceous radiolarians were observed in thin section. Shell fragments are also present, though not highly abundant (Fig. F11). Clay minerals are present throughout the rocks, most likely formed from alteration of volcaniclastic material. Sand-sized rounded carbonate grains are present in thin sections from Section 324-U1350A-26R-3. Four small brachiopod shells $(\sim 1.5 \mathrm{~cm})$ were ob- served in this section $(26 \mathrm{R}-3,69-78 \mathrm{~cm})$. Their shells are thin and have been completely recrystallized with a coating of small sparry calcite crystals growing inside.

\section{Interpretation}

\section{Unit I}

The black cherts interbedded with softer calcareous sediments at Site U1350 probably represent the same broad unit as the stratigraphic Unit I division at both Sites U1346 and U1347 on Shirshov and Tamu massifs, respectively. In comparison to Sites U1348 and U1349 and biostratigraphic indicators (see "Paleontology"), the red and brown chert pieces retrieved from the wash core (324-U1350A-1W) were likely formed during the mid-Cretaceous, whereas the black chert in Cores 3R through 6R is Early Cretaceous in age. This unit was probably deposited in a relatively deep pelagic setting (but above carbonate compensation depth) where the dominant primary sediment was likely to have been radiolarian-bearing nannofossil oozes. Remobilization of biogenic silica associated with diagenesis is the most reasonable explanation for chert development within the sediments. The degree of mottling and relict burrow structures suggest an oxic depositional environment with an active benthic community. However, the subsequent pyritization of these biogenic traces indicates reducing conditions and postdepositional alteration.

\section{Sedimentary interbeds within igneous basement (Units II-IV)}

A significant quantity of sedimentary material was recovered within the basaltic basement. All of these sediments have compositions and structures consistent with submarine deposition. The textural features in the surrounding igneous strata support this interpretation (see "Igneous petrology"). The majority of the sediments are calcareous, mostly limestones or volcaniclastic limestones. The volcaniclastic component in some limestones appears highly altered, especially in Subunit IIa. Clusters of framboidal pyrite present within the limestone matrix always occur in association with weathered volcanic grains and are not present elsewhere in the rock. This suggests the pyritization took place within the igneous rocks themselves shortly after the formation of the basaltic material and prior to its incorporation into the sediments.

The presence of high amounts of micritic carbonate indicates a relatively shallow emplacement depth for both the sediments and the surrounding igneous units. The maximum depth of deposition must have 
been above the lysocline. The consistently high proportion of moderately to poorly preserved calcite-replaced radiolarians within the limestones suggests a high-productivity zone, probably associated with paleoequatorial upwelling.

The paleodepth and depositional environment is further constrained by the presence of macrofossils, such as brachiopods and bivalves (especially at the base of Unit IV); these fossils are associated with shallow-water oxic conditions. The proportion of intercalated sediments to basalt is highest in Unit IV, where the presence of lithified limestone between friable pillows has evidently aided drilling recovery. Distortion of the limestones where they contact igneous rocks suggests the basaltic pillows were extruded into a calcareous ooze prior to lithification, where the lavas subsequently chilled. This is also evidenced by the many chilled (glassy) margins on the pillow edges, which can be seen throughout this unit. The intercalated sediments often have cracked, blackened margins and waxy textures presumably caused by dehydration and baking upon close contact with the still-cooling basalt.

Other nonlimestone sedimentary rocks are present in Units II and IV. Although the recovery of these is generally restricted to isolated pieces, they are typical of materials deposited near submarine volcanic eruptions, as the primary composition of the grains in these calcite-cemented sandstones is volcanic glass, altered hyaloclasts, or fine ash.

\section{Paleontology}

Sediments recovered from Site U1350 include several pieces of red and black chert (Cores 324-U1350A-1W to 9R; Unit I and Subunit IIa; see "Paleontology"). Discrete chert pieces found in the Subunit IIa basalts are most likely displaced from the upper levels by rotary core barrel (RCB) drilling. Shipboard calcareous microfossil studies were performed on limestones that encrusted cherts. In addition, numerous intercalated pelagic limestones between pillow lavas in Unit IV (Cores 25R and 26R) were also investigated.

Calcareous nannofossils from Unit I and Subunit IIa are frequent to high in abundance and moderately to poorly preserved. As a whole, the assemblage is indicative of Early Cretaceous age (Hauterivian-Albian). Planktonic and benthic foraminifers are almost barren in these two units, with only a few silica-replaced specimens. Interpillow pelagic limestones of Unit IV are severely recrystallized and do not yield any calcareous microfossils. A low-diversity, poorly preserved radiolarian assemblage is present in the foraminiferal samples of Site U1350.

\section{Calcareous nannofossils}

The calcareous nannofossils in the chert-encrusting limestones from Site U1350 (Unit I and Subunit IIa) are frequent to abundant and moderately to poorly preserved. The sediments recovered below this interval are barren of calcareous nannofossils.

Sample 324-U1350A-1W-1, 5-6 cm, contains Eprolithus floralis, Staurolithites siesseri, and Zeugrhabdotus diplogramus (Table T2), which allows assignment to Zone NC8 (Albian). The occurrence of Cretarhabdus striatus and Cruciellipsis cuvillieri together with Haqius curcumradiatus and $S$. sisseri in Sample 324U1350A-1W-1, 9-10 cm, immediately below, implies a mixture of calcareous nannofossil taxa of the Lower to mid-Cretaceous (Hauterivian-Albian) (Table T2). An almost identical nannofossil assemblage is recorded from Sample 324-U1350A-3R-1, 5-6 cm. Beneath, Sample 324-U1350A-4R-1, 18-19 cm, contains C. cuvillieri, Rotelapillius crenulatus, and Speetonia sp., which point to Zone NC4 (Hauterivian).

The calcareous nannofossils from Samples 324U1350A-6R-1, 10-11 cm, and 8R-1 (Piece 1, 2-4 cm), both derived from discrete chert pieces that are most likely displaced from upper sediments, indicate the Berriasian to Albian by the presence of Rhagodiscus asper and Staurolithites crux. Sample 324-U1350A-9R1 (Piece 2, 10-11 cm) illustrates a mixed assemblage of the Lower to mid-Cretaceous by the presence of Axopodorhabdus albianus, C. cuvillieri, Rhagodiscus angustus, and Zeugrhabdotus erectus.

In summary, the age of studied Unit I and Subunit IIa is most likely the Berriasian to Albian

\section{Foraminifers}

Both planktonic and benthic foraminifers are nearly barren in the chert-encrusting limestones in Unit I and Subunit IIa. Individuals encountered are one hedbergellid specimen (planktonic foraminifer; Sample 324-U1350A-1W-1, 9-10 cm) and one Dorothia specimen (benthic foraminifer; Sample 324-U1350A$5 \mathrm{R}-1,4-5 \mathrm{~cm}$ ), both of which are replaced by silica and give no information on age or paleowater depth. Likewise, no foraminifer specimen was retrieved from intercalated pelagic limestones between pillow lavas in Unit IV (Cores 324-U1350A-25R through 26R).

\section{Igneous petrology Stratigraphic unit description and volcanology}

In this site report the stratigraphic units are given Roman numbering (stratigraphic Units I-IV), 
whereas the small-scale lithologic units identified during core description are given Arabic numbering (lithologic Units 1-183). We have identified these lithologic units on the basis of sedimentological changes or, in the case of volcanological units, criteria including the presence of chilled margins or contacts, identifiable flow tops, vesicle distribution, and the occurrence of intercalated volcaniclastic or sedimentary horizons. When considered together, these criteria define the various sizes of individual volcanic inflation units. Accordingly, in the volcanic context, the term "stratigraphic unit" is used to combine smaller consecutive inflation units of similar character into lava packages or single eruptive sequences (see "Igneous petrology" in the "Methods" chapter).

Drilling at Site U1350 penetrated $\sim 143 \mathrm{~m}$ of sediment (Unit I) and $\sim 173 \mathrm{~m}$ of volcanic basement (Units II-IV). Volcanic basement was drilled beginning with Core 324-U1349A-6R at 143.1 mbsf (Figs. F12, F13). Recovery was relatively high in the volcanic basement (15\%-96\%), but the contact between the overlying sediment and basement was not recovered. In order of increasing depth, the volcanic basement consists of a series of massive basalt flows intervening with a subordinate proportion of smaller inflation units that passes down first into a transitional zone of roughly equal proportions of massive flows and smaller inflation units, and then into a package dominated by aphyric to sparsely plagioclase phyric pillow lavas (Unit II). Below this lies a layer of hyaloclastite and brecciated basalt (Unit III) and then a short succession of well-preserved plagioclase-phyric pillow lavas set in a matrix of micritic limestone (Unit IV). Coring in the hole and for Expedition 324 terminated at $\sim 315.8$ mbsf (Core 324U1349A-26R). Because of technical difficulties, it was not possible to obtain information using downhole logging tools. Therefore, interpretation of the cored succession is based upon observational and analytical techniques. Unlike other holes drilled during Expedition 324, it was not possible to corroborate stratigraphical interpretation with downhole data.

The basalts of Unit II (Fig. F12) consist of aphyric basaltic lavas ranging in thickness from a few large 3-6 $\mathrm{m}$ units with homogeneous nonvesicular cores to smaller 1-2 $\mathrm{m}$ pillowlike units readily identifiable from their glassy rinds, thick chilled upper and lower margins, and rare instances of flow-to-flow contacts. Overall, Unit II is a progression from predominantly thick flow units with repeated occurrences of intercalated sedimentary horizons in the top of this succession to a densely packed pillow lava stack at the base of this unit lacking any sedimentary horizons. In the absence of other information, including downhole logging data, this volcanic succession is arbitrarily divided into three subunits based on the type and relative importance of different flow units and the associated frequency of sedimentary intercalations. The topmost $77 \mathrm{~m}$ (Subunit IIa) consists predominantly of larger, internally homogeneous inflation units, the middle $\sim 21 \mathrm{~m}$ is of both massive and pillowed inflation units (Subunit IIb), and below this is a $\sim 50 \mathrm{~m}$ stack of $0.2-0.9 \mathrm{~m}$ thick, aphyric to sparsely plagioclase-phyric pillow lava units (Subunit IIc). These pillow units lie above $\sim 6 \mathrm{~m}$ of hyaloclastite (Unit III) with a black, fine-grained matrix containing gravel- to sand-sized glassy material, hyalobasalt fragments, and/or small pods $(\sim 5-15 \mathrm{~cm})$ of aphyric basalt (Sections 324-U1350A-24R-3 through 25R-1). The basalt in the small pods of Unit III is very similar to that of Unit II above, but occurs in a hyaloclastite facies interpreted as having formed by cooling-contraction granulation, mass wasting, and/ or autobrecciation. The contact between the base of Unit III and the volcanic succession beneath was not recovered. The lowermost $\sim 19 \mathrm{~m}$ is composed of a thick succession (Unit IV) in two high-recovery $(>90 \%$ ) cores (Cores 324-U1350A-25R and 26R) that preserve, in great detail, a stack of $\sim 0.1-0.5 \mathrm{~m}$ thick plagioclase-phyric pillow lavas. This pillow stack includes many good examples of thick chilled margins, internal vesiculation patterns, pillow/pillow contacts, and pillow/sediment contacts with intervening zones of thermal alteration. The sediment consists of a micritic limestone that in many instances encase pillow units, which, together with a lack of bedding structure, indicates that these pillow lavas were extruded onto, or into, an unconsolidated or fluidized micritic sediment substrate.

\section{Upper massive basalt flows and lower pillow lavas (stratigraphic Unit II, lithologic Units 2- 90)}

The upper part of the volcanic basement (Subunit IIa) consists of a $\sim 77 \mathrm{~m}$ thick sequence of massive aphyric basalt inflation units (Cores 324-U1350A-6R through 16R) (Fig. F14). Recovery through this sequence was $15 \%-66 \%$, with recovered sections of these massive units ranging between $\sim 1.5$ and $4 \mathrm{~m}$ thick. These massive basalt flows have glassy subhorizontal margins, horizons of vesicle accumulation in the upper parts of the flow, pipe vesicles, associated vertical and horizontal segregation features within the homogeneous flow cores, and little evidence of internal jointing or fracturing. These features are best preserved in the 3.0 and $5.4 \mathrm{~m}$ thick flows of lithologic Units 10 and 11 (recovered in Sections 324-U1350A-9R-1 through 10R-2). In addition, this upper part of the volcanic basement is sparsely inter- 
calated with thin limestones containing recrystallized microfossils, comminuted shell debris, and altered volcaniclastic (glassy) particles. The lowermost of the major lavas in Subunit IIa is a $2.5 \mathrm{~m}$ thick lava flow (lithologic Unit 27), below which the first readily identifiable pillow lava occurs (lithologic Unit 29) in Section 324-U1350A-17R-1. This pillow lava comprises the top of the transition succession of Subunit IIb.

Subunit IIb is a $\sim 21 \mathrm{~m}$ thick zone representing a changeover from thicker basalt units to dominantly pillow-type basalts (Sections 324-U1350A-17R-1 through 18R-3). It contains five larger lava units ( 1$2.5 \mathrm{~m}$ thick) intercalated with smaller pillowlike inflation units $(<0.5-1 \mathrm{~m}$ thick) or intervals of fragmentary pillow lava (i.e., hyaloclastite) material. The smaller inflation units display chilled margins, glassy contacts, and typical pillowlike radial vesicle distribution patterns, together with sparse sedimentary intercalations similar in composition and content to those fragments in Subunit IIa. The limited recovery of these materials makes any further interpretation regarding the original thickness or internal structure of these sediment intercalations difficult.

Subunit IIc is a $\sim 50 \mathrm{~m}$ succession of $0.2-0.9 \mathrm{~m}$ thick aphyric and sparsely phyric pillow lavas (Sections 324-U1350A-19R-1 through 24R-2) with dimensions and internal structures (e.g., subvertical pipe vesicles and segregation pipes) similar to those observed in cores from Holes U1346A and U1347A. The first well-preserved evidence of a more continuous pillow lava stack occurs in Section 324-U1350A-19R-2 (lithologic Unit 41) and contains several folds in glassy crust and small lava pods interspersed with brecciated pillow material. The top of this $\sim 50 \mathrm{~m}$ succession contains three $\sim 1-1.5 \mathrm{~m}$ thick, more homogeneous lava flow units and minor sedimentary material typically preserved as a lava/sediment contact.

The lowermost $\sim 23 \mathrm{~m}$ of Subunit IIc contains no sedimentary material and is a continuous sequence of pillow lavas displaying millimeter-sized, sparsely scattered amygdules, curvilinear glassy rinds with microvesicular bands with tube- and drop-shaped vesicles, and interpillow tension cracks with chilled margins and jointing patterns (Fig. F15). Plagioclase phenocrysts (up to $2 \%$ ) are sparsely distributed throughout the basaltic material within this pillow stack. This lowermost pillow lava stack correlates well with an interval of low magnetic susceptibility (see "Physical properties"), which may itself be a result of the presence of plagioclase phenocrysts, a finer grain size, and/or an increased degree of alteration.

\section{Hyaloclastite and pillow breccia (stratigraphic Unit III, lithologic Unit 91)}

A distinct horizon of hyaloclastite and pillow breccia was recovered in Sections 324-U1350A-24R-3 through 25R-1 (Fig. F16); it is $\sim 6 \mathrm{~m}$ thick and consists of a mixture of poorly sorted angular glass shards and spalled pillow material $(0.2-5.0 \mathrm{~cm})$, plagioclase crystal fragments, and globular basaltic lava inclusions (or pods) $(5-15 \mathrm{~cm})$. No internal bedding or grading can be discerned in this unit. A dull black glassy matrix constitutes the bulk $(>50 \%)$ of the deposit, and the greenish glass shard fragments themselves consist of partially devitrified material, vitric black clasts, and sparse plagioclase phenocrysts $(<2-$ $5 \mathrm{~mm}$ in size). The breccia is monomict (i.e., it only contains fragments of quenched basaltic material) and is clast or matrix supported, depending upon the relative proportions of fine to coarse constituents. The isolated globular inclusions of lava are internally highly fractured, moderately vesicular, and also contain sparse plagioclase phenocrysts. The larger pods of basaltic material have rudimentary chilled margins and glassy rims, indicating that they were incorporated or intruded into the deposit while in a near molten state. Like the immediately overlying pillow lava unit, the fine-grained basaltic inclusions and glass fragments are sparsely plagioclasephyric, sparsely vesicular basalt, suggesting that the two are petrogenetically related. The hyaloclastite succession is likely to represent the onset of the magmatism that initially produced the overlying pillow lava stack of Subunit IIc.

\section{Lower pillow lavas with interpillow sediment (stratigraphic Unit IV, lithologic Units 92-183)}

The lowermost $\sim 19 \mathrm{~m}$ thick volcanic succession (Unit IV) consists of two consecutive cores (324U1350A-25R and 26R). These cores preserve a stack of $\sim 0.1-0.5 \mathrm{~m}$ thick plagioclase-phyric pillow lavas in great detail, including the sedimentary material between the individual small inflation units. Exceptional recovery of drill core in the lower pillow lava Unit IV (93\%-96\%) provides a nearly complete sequence of pillow lavas. Accordingly, the lower unit of pillow lavas is remarkable for its preservation of pillow lava structures and glassy chilled margins and their relationships with surrounding sediment and associated alteration effects on the sediment. The details of some of the best preserved features are shown in Figures F17, F18, and F19.

Almost all of the glassy rinds and chilled margins are preserved intact, and pillow/pillow contacts as well as pillow/sediment contacts are abundant throughout these cores. For instance, the cores show exam- 
ples of otherwise rarely preserved delicate features, such as in situ spalling of pillow rim material, fractured and fragmented jigsaw-fit textures of chilled basalt, and marginal cracking of the pillow. Cracking patterns resulting from cooling and contraction can been seen to have ruptured the crust and penetrated through the inner chill boundaries into the pillows cores themselves, which would have permitted further cooling through the penetration of water along the neoformed joints (McPhie et al., 1993). Many of these preserved features are likely to have formed as a result of in situ cooling, cracking, and contraction and indicate that relatively little transport or compaction occurred after emplacement.

The topmost sedimentary intercalation within this pillow stack is a single, thin $(\sim 15-25 \mathrm{~cm})$ horizon, which, in its upper part consists of fine-grained hyaloclastite sand (interval 324-U1350A-25R-1, 126-149 $\mathrm{cm})$ and preserves complex structural detail. The finer grained portion of this hyaloclastite comprises densely packed glass shards that have been compacted and lithified before being deformed; the laminations within it are fractured and intruded by fingers of melt. The coarser beds are composed of more porous glass shard material with voids filled by carbonate cement. The remainder of the sedimentary intercalations in the pillow stack below this horizon is fine-grained micritic limestone containing common radiolarian tests entirely replaced by carbonate and shell debris. The limestone is homogeneous and contains no discernable sedimentary structure, with the exception in some instances of fine laminations of volcanic particles that may indicate post-eruptive sedimentary draping of the lava pillows (interval 324-U1350A-26R-5, 90-130 cm).

\section{Preliminary assessment}

The cored volcanic basement at Site U1350 is an entirely marine volcanic succession but exhibits two different styles of seafloor basaltic volcanism. The initial (basal) lava succession (Unit IV) consists of small but complete pillow lavas erupted into a marine environment in which there was an abundant supply of micritic sediment. The second lava succession (Unit III followed by Unit II) begins with the production of hyaloclastite before building into a series of larger pillowlike inflation units. These latter units were either erupted sufficiently rapidly to prevent any significant accumulation of interpillow sediment, or else they were erupted into a sedimentstarved environment. The presence of pillow/pillow contacts (Sections 324-U1350A-22R-4 and 22R-5) could indicate merging of adjacent eruptive pods. It may also indicate a multiple-pod inflation mechanism that produces eruptive units that are laterally more extensive and which can exhibit relatively slow cooling characteristics. The slow cooling, for example, may explain their internally homogeneous texture, together with well-developed pipe vesicles and degassed cores observed in many of the inflation units.

The different types of pillow lavas that form Unit IV as compared with those at the base of Unit II require further explanation. The lower pillow stack of Unit IV consists of small, rounded pillow lavas displaying most of the typical structures (e.g., chilled zones, vesicle patterns, and internal structure). The thick, well-formed glassy rinds indicate each pillow was erupted and cooled as an individual entity. However, those pillow lavas that constitute Subunit IIc differ in that they are larger, the glassy contact margins are thinner, and their chilled margins are less well developed. In Subunit IIc, the tube- and drop-shaped vesicles characteristic of the marginal chill zones are often restricted to a narrow, sparsely vesicular zone immediately inward of the contact, and the well-developed concentric vesicle bands indicative of both significant internal degassing and progressive cooling are absent. Moreover, internal cooling cracks and associated radiating vesiculation patterns are also noticeably absent in the larger pillowlike eruptive units. It is reasonable to conclude that these two pillow stacks represent subtly different eruptive styles and, presumably, different magma gas contents.

In general, only a small proportion of pillow units that form in typical pillow lava fields and stacks consists of self-contained and separate erupted entities. Most pillow lavas form through a processes of internal inflation, expansion, and rupture; eventually lava will break out from the chilled crust through a process of "budding" to form a new, magmatically interconnected lobe or pillow. As this process continues it eventually forms networks of interconnected tubes and lobes that together make up the pillow lava field (Moore, 1975; Yamagishi, 1985; Walker, 1992). Walker (1992) suggested that the nature of the lobe expansion (i.e., the production of multiple or discrete entities) is influenced by lava viscosity. Crust rupturing is more common in the more viscous basalt lavas, and hence internal cooling is augmented through penetration of water along fractures; more viscous basalt leads to the development of discrete pods or pillows rather than an interconnected network. Low-viscosity lavas have more elastic, hence largely unbroken, crusts and together with slower cooling rates produce pillows with smoother surfaces and an anastomosing, interconnected magmatic plumbing between the inflation units. Other variables that control the morphology of submarine lava flows include effusion rate, flow velocity, and 
local or regional slope of the seafloor (e.g., Batiza and White, 2000; Gregg and Smith, 2003). The relatively thin glassy rind and chill zones, together with the absence of interpillow sedimentary material in Subunit IIc, could be interpreted as rapid accumulation of interconnected low-viscosity lava pods, each remaining hot while the adjacent one budded and erupted. Pillowed lava units of Unit IV display characteristics of higher viscosity lavas and a more rapid cooling, including the complex internal fracture patterns and thick well-developed glassy rinds and chilled zones. Moreover, the pillow lavas from Unit IV are distinct in that they are distinctly more plagioclase-phyric, a factor which is known to significantly increase lava viscosity (Jerram et al., 2003).

Finally, during the development of pillowed lava flows, interaction with preexisting sediments can occur under a wide range of physical conditions. If the eruption encroaches in an area of previous seafloor sedimentary deposition, the nature of the interaction of the pillows with these sediments will depend upon the physical nature of the substrate and its grain size (i.e., whether they are muds, sands, or pebbles/breccia and whether it is consolidated, cemented, or unlithified). The contact between (wet) sediment and lava in Unit IV is, in most cases, well defined and marked by $1-2 \mathrm{~cm}$ zones of baking/alteration. In addition, the contacts between the pillow lavas and sediment also exhibit more complex relationships. Interpenetration and occurrences of finegrained carbonate sediment mixed with basaltic lava, or irregular enclaves of deformed and altered sediment, can be observed in the contacts between some pillows (Fig. F19). There is a lack of any bedding or lamination in the sediment, and some of the pillows are entirely encased or "suspended" within a sediment envelope. A likely explanation of these pillow lava-sediment relationships is fluidization of the fine-grained sediment occurred, attributable to flash heating and vaporization of sediment pore water during emplacement of the pillow lava (Kokelaar, 1982). Such momentary fluidization causes sediment reconstitution, the destruction of any inherent bedding structures, and localized transport of the material. It thus is likely that the pillow lavas of Unit IV were emplaced into unconsolidated fine-grained micritic sediment that was fluidized, mobilized, and either injected, squeezed, or otherwise redeposited between individual close-packed pillows to produce the observed intricate pillow lava/sediment contacts.

\section{Petrography and igneous petrology}

The petrography in Hole U1350A is described according to the volcanological divisions described above (Units II-IV). The glassy and finely spherulitic margins occurring around both pillows and flows show that plagioclase and clinopyroxene, both separately and intergrown, occur in tiny stellate aggregates as quench minerals. Olivine is present as a microphenocryst. No spinel occurs. Some of the rocks have moderate abundances of large tabular plagioclase microphenocrysts, phenocrysts, and glomerocrysts. The glomerocrysts reveal complex crystallization and cooling histories for the plagioclase and can have skeletal interiors with inclusions that were formerly glass but that are now darkened by spherulitic crystallization and alteration. With the exception of Unit IV, the fluctuations of phenocrysts do not appear to delimit different compositions of basalt (Table T3). The rocks of Units II and III pertrographically resemble the moderately to strongly differentiated rocks of Hole U1347A. A summary table of thin section descriptions of the volcaniclastic rocks is given in 324GLASS.XLS and the contacts between lithologic units are described in 324UNIT.XLS in LOGS in "Supplementary material."

\section{Upper massive flow succession (stratigraphic Subunit Ila, lithologic Units 2-27)}

The petrography of the upper massive basalt lava flow units of Subunit IIa (Cores 324-U1350A-6R through 16R) is described on the basis of observations on 24 thin sections from 18 inflation units. These lavas are typically sparsely vesicular $(\sim 1 \%-$ $15 \%)$ and aphyric to sparsely plagioclase phyric $(<1 \%)$, with individual phenocrysts as large as 2.0 $\mathrm{mm}$. Plagioclase microphenocrysts are usually present as glomerocrysts. Plagioclase phenocryst and microphenocryst abundances (Fig. F20) within units of the lower part of Subunit IIa are slightly elevated ( 1\%) with respect to those of upper part (trace). In addition, traces of olivine and clinopyroxene occur as small phenocrysts and/or microphenocrysts near the bottom of Subunit IIa. Olivine phenocrysts sometimes occur in skeletal forms $(<1.2 \mathrm{~mm})$ and are typically pseudomorphed by brown clay (see "Alteration and metamorphic petrology"). Clinopyroxene phenocrysts or microphenocrysts usually subophitically enclose acicular microcrysts of plagioclase or form glomerocrystic aggregates with tabular plagioclase. Groundmass textures in the interiors of the upper massive flows are predominantly intersertal, intergranular, spherulitic, and variolitic. The size of groundmass minerals ranges from microcrystalline near margins of the flow units to very fine grained at the interior part of relatively thick flows $(>2 \mathrm{~m})$, where crystallinity is also high (up to $\sim 70 \%$ ). Occasionally, fresh glass is preserved as patches within spherulites in some chilled margins. 


\section{Transitional succession (stratigraphic Subunit Ilb, lithologic Units 28-38)}

The petrography of massive flows and pillow lavas in the transitional succession (Subunit IIb) is based on seven thin sections from seven inflation units (Sections 324-U1350A-17R-1 through 18R-3). They are of sparse vesicularity $(2 \%-5 \%)$ and aphyric to sparsely plagioclase-phyric $(<2 \%)$. Plagioclase phenocrysts and microphenocrysts are the predominant minerals, present as glomerocrysts forming aggregates as large as $2 \mathrm{~mm}$. Rare clinopyroxene microphenocrysts observed at the top of Subunit IIb subophitically enclose acicular microcrysts of plagioclase and form glomerocrystic aggregates with tabular plagioclase. Olivine phenocrysts are not observed in Subunit IIb. Groundmass textures of the lava units in the transitional succession are predominantly intersertal, hyalophytic, spherulitic, and variolitic. Groundmass sizes range from microcrystalline near the margins of flows or thin-flow interiors to very fine grained at the interior part of relatively thick flows $(>1 \mathrm{~m})$. Crystallinity is as high as $\sim 50 \%$ in the cores of the thicker flows and is lower than that of Subunit IIa.

\section{Aphyric pillow succession and hyaloclastite (stratigraphic Subunit IIC and Unit III, lithologic Units 39-91)}

The petrography of Subunit IIc and Unit III is based on 14 thin sections from 14 inflation units in Subunit IIc and 1 thin section from Unit III (Sections 324-U1350A-19R-1 through 25R-1). These basalt units are sparsely vesicular $(1 \%-5 \%)$, aphyric at the upper part of Subunit IIc (240-270 mbsf), and sparsely phyric $(<2 \%)$ at the base of Subunit IIc (270290 mbsf) (Figs. F12, F20). In both Subunit IIa and Unit III, plagioclase phenocrysts and microphenocrysts are the main minerals, usually present as glomerocrysts forming aggregates as large as $2 \mathrm{~mm}$. Olivine and clinopyroxene are rare as microphenocrysts. Olivine microphenocrysts $(<0.5 \mathrm{~mm})$ are pseudomorphed by brown clay (see "Alteration and metamorphic petrology"). Clinopyroxene microphenocrysts form glomerocrystic aggregates as large as $0.5 \mathrm{~mm}$. Groundmass textures in the aphyric pillow lavas (Subunit IIc) are dominantly intersertal, hyalophytic, and spherulitic. Groundmass size is mostly microcrystalline within the flow interiors and cryptocrystalline nearer the unit margins. Fresh glass showing spherulitic textures is preserved as glassy rinds at the lowermost chilled margins of some flows (Thin Section 312; Sample 324-U1350A-24R-1, 128$131 \mathrm{~cm})$. The crystallinity of the aphyric pillow succession (Subunit IIc) reaches a maximum of $\sim 50 \%$, which, although low, is comparable to that of the transitional succession (Subunit IIb). The hyaloclas- tite of Unit III has a cryptocrystalline groundmass with hyalophytic fragments.

\section{Plagioclase-phyric pillow succession (stratigraphic Unit IV, lithologic Units 92-183)}

The petrography of Unit IV is based on 15 thin sections from 14 inflation units (Cores 324-U1350A$25 \mathrm{R}$ and $26 \mathrm{R})$. They are sparsely vesicular $(3 \%-5 \%)$ and sparsely to moderately plagioclase-phyric (2\%5\%). Plagioclase phenocrysts and microphenocrysts are the predominant minerals, usually present as glomerocrysts forming aggregates as large as $5 \mathrm{~mm}$. Some individual plagioclase phenocrysts $(<5 \mathrm{~mm})$ are anhedral and have sieved textures, honeycomb textures, and rim-resorption features. Rare olivine microphenocrysts are observed at the top of Unit IV but are pseudomorphed by brown clay and calcite (see "Alteration and metamorphic petrology"). Groundmasses in the plagioclase-phyric pillow succession have hyalophytic textures with phenocrysts of plagioclase and pyroxene. The groundmass is dominantly cryptocrystalline at flow interiors and near the flow margins. Chilled margins of the pillows consist mainly of spherulite or fully altered glass to clay minerals (see "Alteration and metamorphic petrology"). Crystallinity of the pillow succession of Unit IV is $<30 \%$.

\section{Two types of groundmass crystal morphologies}

Since many of the rocks are comparatively unaltered, differences in texture are immediately apparent in reflected light. These differences are not always obvious when dark, microcrystalline material is observed in transmitted light because of the "clouding effect" of superimposed crystal interference(s) through the thickness of the thin section. Reflected light, instead, provides a single surface for examination, and crystal shapes are sharply outlined. Using this technique, two principal textural types of rock become apparent in Hole U1350A (Fig. F21):

Type 1 can be termed the "plagioclase network" type (Fig. F21A, F21B). In this type, the largest plagioclases are usually acicular crystals with bifurcating arms projecting only short distances outward from the ends, but appearing as a loose skein across the thin section. Smaller, but irregular and dendritic, clinopyroxene probably occurs between the plagioclase crystals, as does formerly glassy intersertal material that is darker brown. In reflected light, the faceted crystal outlines of plagioclase (darker gray) are prominent, yet the clinopyroxene (brighter gray) is a smaller proportion of the modal abundance and does not stand out, being almost hidden between the feldspars (Fig. F21B). Titanomagnetite (bright white, in the same image) is skeletal and occurs 
mainly within the dark intersertal material. Some Type 1 basalt has what appear to be irregular segregation patches as long $1 \mathrm{~cm}$ in some thin sections (Fig. F21E, F21F).

Type 2 can be termed the "plagioclase-clinopyroxene network" type (Fig. F21C, F21D). In this type, the basalts have dozens of fairly coarse grained intergrowths of tabular plagioclase and subhedral clinopyroxene forming a network of "islands" within a finer grained dark matrix (Fig. F21C, F21D). Plagioclase in the islands is tabular and euhedral, although it may project skeletally into the matrix. The clinopyroxene has, at most, only tiny dendritic projections into the matrix, whereas the matrix itself consists of elongate skeletal to feathery plagioclase of various sizes that do not form a network skein. Small amounts of clinopyroxene cluster within the interstices of the feldspars. Titanomagnetite cannot be distinguished at this magnification.

Figure F22 shows, sequentially through the core, a series of reflected light photomicrographs. From the first five of these (Fig. F22A-F22D), differences in average grain size and crystallinity (highlighted in reflected light) are mainly the result of placement of the thin sections in different portions of the basalt flow interiors that cooled at different rates. But the general similarity of Type 1 plagioclase skeining is evident in all of them. Type 2 networking is only present in the thin sections shown in Figure F22E, F22F and F22G. In the finer grained rock of Figure F22F, the bulk of the rock is occupied by finely crystalline plagioclase-clinopyroxene intergrowths that clump between small, dark intersertal patches. Figure F22G also shows a groundmass Type 2 network, again plagioclase-clinopyroxene intergrowths set in a matrix of the sample previously shown in Figure F21C and F21D.

The photomicrographs in Figure F22 are arranged by core depth. From this, all of Subunit IIa consists of Type 1 basalt except for one sample (Fig. F22E, Sample 324-U1350A-16R-3, 35-39 cm), whereas Subunit IIb is Type 2. Figure $\mathbf{F} 22 \mathbf{H}$ depicts the uppermost thin section of the lower Subunit IIc, and it shows a Type 1 networking again, after which the Type 1 plagioclase skeining prevails to the bottom of the hole. The thin section from Unit III (Thin Section 311; Sample 324-U1350A-24R-3, 35-38 cm) has a cryptocrystalline texture, which precludes identification of groundmass texture. Petrographically, then, there are at least three (and probably four) different rock types among the basalt in Hole U1350A. In sequence upward, they correspond to Units IV and III combined and although Subunits IIc and IIa are very similar petrographically, they are separated by something that is petrographically distinct in Subunit IIb.
Finally, Figure F23 shows representative phenocryst and glomerocrystic clusters. Figure F23A-F23D is from a single thin section of Type 1 basalt. In it plagioclase and clinopyroxene occur both as clumps or clusters and as separate phenocrysts. Plagioclase also occurs in monomineralogic glomerocrysts. Figure F23E shows a single but complex Type 2 networking intergrowth of plagioclase and clinopyroxene. The plagioclase is skeletal but fairly well faceted; it is arranged like randomly projecting nails held in a clinopyroxene fist. In Figure F23F, a reflected-light image of the left portion of the intergrowth in the previous photomicrograph, the outlines of clinopyroxenes are the straight boundaries of plagioclase crystals on one side but are very irregular at the edges of intersertal patches on the other. The pyroxenes are also full of unpolished specks, an indication of the bladelike or dendritic tendency of its crystal morphology.

The tendency might be to discern the arrangements of these intergrowths in Hole U1350A basalts as microphyric clusters or even phenocrysts. However, in the same manner as the ophimottle clots in Hole U1349A are not phenocrysts, the intergrowths in Hole U1350A perhaps are derived from a deep-seated magma chamber. Type 1 and 2 crystal networks also occur in the basalts in Hole U1347A, but in Hole U1350A we see a more explicit development of their features. Further evaluation along these lines will depend on assessment of crystal morphologies at quenched pillow margins in shore-based thin section studies, the detailed development of a chemical stratigraphy, and comparison with basalts of other holes drilled during Expedition 324.

\section{Preliminary assessment}

Comparing all basalt drilled at Sites 1213, U1346, U1347, U1349, and U1350, it becomes evident that Shatsky Rise presents a basaltic province in which plagioclase-clinopyroxene intergrowths, from the stage of earlier crystallization of mottles with ophitic textures (Hole U1349A) to the formation of phenocrysts and glomerocrysts (Holes 1213B, U1347A, and U1350A) to the quench stage and to the stage of coarser grained crystallization in the interiors of flows and pillows, are well developed in all holes. This petrographic attribute is evident even among the rare and tiny quench crystals in the one glassy sample recovered among the hyaloclastites of Hole U1348A. Basalt in Hole U1346A and in particular Hole U1349A is more primitive than the others, since it contains fairly abundant olivine and $\mathrm{Cr}$ spinel, whereby even plagioclase-clinopyroxene intergrowths occur in remnants of altered glass margins. Petrologically, this attribute indicates that at all 
stages of crystallization the temperature interval between onset of plagioclase crystallization and that of clinopyroxene was negligible. Experimentally, this is not a usual feature of mid-ocean-ridge basalt (MORB) at low pressure, with the exception of the melt containing significant dissolved water, since these conditions would allow a basalt to crystallize plagioclase and clinopyroxene together.

Although some of the basalt in Hole U1349A can be termed picritic, they differ from the only well-documented picrite found on modern spreading ridges, such as that of Siqueiros Fracture Zone on the East Pacific Rise (Natland, 1980). More evolved olivine tholeiite from drill sites on the Mid-Atlantic Ridge still has an obvious gap in crystallization temperature between the onset of crystallization of plagioclase and later clinopyroxene (e.g., Kirkpatrick, 1979). As MORB-like as Shatsky Rise basalt may be in its geochemistry, in this one respect, it is different.

\section{Alteration and metamorphic petrology}

The entire section of basaltic rocks (massive lava flows, pillow lavas, and hyaloclastites) recovered from Hole U1350A has been affected by slight to high degrees of low-temperature water-rock interaction, resulting in complete replacement of glassy mesostasis and olivine phenocrysts and slight to almost complete replacement of groundmass minerals (plagioclase and clinopyroxene). In contrast, plagioclase phenocrysts are generally well preserved throughout the hole, except in portions of stratigraphic Unit IV. Fresh glass is commonly preserved on the margins of flows and pillows in Subunits IIa and IIb, rarely preserved in Subunit IIc, and not preserved in Units III and IV. The overall degree of alteration of the basalts ranges from slight to moderate in the upper flow succession and hyaloclastites (Units II and III) to moderate to high in the plagioclase-phyric pillow succession (Unit IV). The degree of alteration was estimated visually using a binocular microscope on the archive half and using an optical microscope on discrete thin section samples, without taking into account the veins and vein halos.

Clay minerals, together with calcite, are the predominant secondary minerals in Hole U1350A, replacing primary phases and glassy mesostasis and filling vesicles and veins. Clay minerals were identified by optical microscopy and X-ray diffraction (XRD) patterns of whole rocks and veins. Nontronite and montmorillonite are the two main minerals replacing the groundmass, whereas an assemblage of saponite \pm nontronite \pm montmorillonite was identi- fied in the veins. Other alteration minerals observed in the basaltic cores are pyrite, zeolites, and likely sanidine. Pyrite is the only sulfide mineral observed throughout the entire basaltic section in Hole U1350A, either disseminated in the groundmass or as constituent of veins and vesicles (Fig. F24). Zeolite was identified at various depths filling vesicles and veins, and sanidine was identified as a replacement of plagioclase phenocrysts in the plagioclase-phyric pillow succession of Unit IV.

Below, alteration degree and mineralogy at Site U1350 are compared with those of basaltic rocks recovered at previous sites at Shatsky Rise, Site U1346 (Shirshov Massif), Site U1347 (Tamu Massif), and Site U1349 (summit of Ori Massif), and with basalts recovered from the Ontong Java Plateau (OJP) (ODP Leg 192) (Mahoney, Fitton, Wallace, et al., 2001; Banerjee et al., 2004).

\section{Alteration description}

Based on core descriptions and thin section observations, alteration style of the basaltic rocks recovered from Hole U1350A is similar throughout the entire hole. Overall alteration degree varies from $10 \%$ to $90 \%$ (Fig. F24; see 324ALT.XLS in LOGS in "Supplementary material"). One type of gray alteration was identified with significant variation in alteration degree that may be related to lithology, in particular to the intercalation of relatively thin massive lava flows and pillow lavas (Fig. F24). In Unit II, alteration is highly variable, ranging from $10 \%$ for the freshest samples to $50 \%$ for the most altered samples (Fig. F25). In the hyaloclastites of Unit III, the glass is completely altered to palagonite and brown clays, whereas plagioclase and clinopyroxene phenocrysts remain relatively unaltered. In Unit IV, alteration ranges from $40 \%$ to $90 \%$ (Fig. F25) and is likely related to the presence of interbedded limestones between the pillow lavas, which may have provided pathways for fluids to circulate and interact with the basalts.

\section{Replacement of primary phases}

Basaltic rocks recovered from Hole U1350A are divided into five petrographic units (see "Igneous petrology") and are mainly massive flows (Subunit IIa), pillow lavas (Subunit IIc and Unit IV), and hyaloclastites (Unit III). These basaltic rocks are dominated by plagioclase as phenocrysts and, in the groundmass, clinopyroxene and titanomagnetite in a cryptocrystalline to glassy groundmass (see "Igneous petrology" for detailed description). Pseudomorphs after olivine phenocrysts are observed from the bottom of Subunit IIa to the top of Unit IV (from Section 324-U1350A-13R-2 to 25R-1). Plagioclase is 
slightly to highly altered to brown and white clays (from $\sim 5 \%$ to $\sim 90 \%$ ), but phenocrysts are commonly less affected by alteration than minerals forming the groundmass. However, in Unit IV, plagioclase phenocrysts are extensively altered (from 50\% to $90 \%$ ), being replaced by brown and green clays and sanidine (Figs. F24, F26). Green clays (possibly associated with minor chlorite) are observed along the edges of plagioclase phenocrysts, whereas brown clays and sanidine are observed as a replacement of the inner central part of the mineral. XRD spectra of wholerock powders also suggest the presence of sanidine in the rocks. As with plagioclase in the groundmass, clinopyroxene microcrysts are slightly to highly altered to brown clays (from $\sim 5 \%$ to $\sim 90 \%$; average $=40 \%$ ). Olivine phenocrysts, when present, are completely pseudomorphed by calcite and brown clays (Mg saponite) in various proportions (Fig. F27). Titanomagnetites are also slightly to extensively altered (from $\sim 10 \%$ to $80 \%$ ) and the glassy mesostasis is completely replaced by brown clays and minor amounts of calcite (Fig. F28). Pyrite is rarely observed in the groundmass of the upper massive flows of Subunit IIa.

\section{Alteration of chilled-margin glass}

A significant number of flow and pillow margins was recovered from Hole U1350A. In Unit II, fresh glass is commonly present within a matrix of altered glass (Fig. F24). Alteration of the glass by the formation of palagonite occurs along veins and vesicle margins. Most pillow margins are rimmed by a $\sim 1 \mathrm{~cm}$ thick, black soft material that is composed of a mixture of clay minerals (i.e., montmorillonite, nontronite, and possibly bannisterite, based on XRD data). This black, soft rim may be a result of either alteration of the pillow margins or clay-rich sediments that have been deposited between pillows or lava lobes. No fresh glass was preserved in the hyaloclastites of Unit III or in the intercalated pillow lavas and carbonate sediments of Unit IV. Variation in degree of alteration between the pillow margins of Subunit IIa, which contain fresh glass, and the pillow margins of Unit IV, which do not contain fresh glass, is shown in Figure F29. Spherulitic material from Subunit IIa is very fresh, with $90 \%$ reflective material (in reflected light), whereas a near identical texture in Unit IV contains only $\sim 10 \%$ reflective material.

\section{Vesicles}

Basaltic rocks recovered from Hole U1350A show variable degrees of vesicularity depending on the lithology (massive flow versus pillow lavas). Vesicles are mainly filled with calcite, pyrite, saponite, and rarely zeolite (Fig. F24). Zeolite-filled vesicles are only observed in three cores (e.g., Sections 324U1350A-8R-3, 20R-3, and 26R-5) (Fig. F30). Vesicles commonly contain a rim of segregated melt that has been altered to dark brown clay minerals and finegrained oxides. These vesicles commonly contain significant pyrite grains. No systematic variation with depth is apparent in the type of mineral filling vesicles (Fig. F24). In the pillow lavas of Unit IV, large vesicles are filled with light green-brown clay, likely saponite, showing floret morphology (Fig. F30) similar to that observed in the highly altered volcanic breccia at the bottom of Hole U1349A.

\section{Veins}

Four main vein types have been identified in basaltic rocks of Units II-IV in Hole U1350A (Fig. F24; see 324VEIN.XLS in LOGS in "Supplementary material"):

1. Calcite veins ( \pm pyrite),

2. Saponite veins,

3. Calcite and saponite veins ( \pm pyrite), and

4. Pyrite veins.

A zeolite vein was identified in only one thin section in the upper part of Subunit IIa (Thin Section 271; Sample 324-U1350A-8R-3, 81-84 cm), and Fe oxyhydroxides were only observed in veins in two thin sections of plagioclase-phyric pillows (Unit IV) (Thin Section 329; Sample 324-U1350A-26R-5, 35-40 cm, and Thin Section 331; Sample 324-U1350A-26R-5, $84-88 \mathrm{~cm}$ ). A total of 461 veins and vein networks were recorded in the $75 \mathrm{~m}$ of recovered rock (average $=6.1$ veins $/ \mathrm{m}$ ). The vein frequency, however, varies significantly through the hole (Fig. F24), with, for instance, 18 veins $/ \mathrm{m}$ in Core 324-U1350A-23R. Veins are typically thin; only three veins thicker than $1 \mathrm{~cm}$ were recorded (Fig. F24).

Most of the veins in Hole U1350A are calcite veins, consisting of either crystalline blocky calcite or cross-fiber calcite. The calcite veins result from symmetrical infilling of open cracks with minor or no replacement of the wall rock. Both cross-fiber and crystalline calcite veins are commonly associated with pyrite. Thin pyrite veins are commonly observed throughout Unit II (Fig. F31A). Saponite ( \pm pyrite) veins are also very common throughout the succession. Multiple generations of veining occurred in Hole U1350A, as shown by the crosscutting relationships demonstrated in Figure F31A-F31C.

\section{Interpretations of alteration}

Basaltic rocks recovered from Hole U1350A have undergone pervasive low-temperature water-rock interaction, resulting in significant variation in the degree of alteration. Variations range from $10 \%$ 
alteration for the Unit II basalts, where significant glass is preserved on pillow margins and flow tops, to as much as $90 \%$ for the plagioclase-phyric pillows (Unit IV) at the bottom of the hole. The predominance of clay minerals (i.e., smectites) and calcite as secondary phases suggests relatively low temperature alteration $\left(<100^{\circ} \mathrm{C}\right)$ (Alt, 1995, 2004; Honnorez, 2003).

Alteration mineralogy in Hole U1350A samples is comparable to that encountered in Hole U1347A on Tamu Massif, with extensive replacement of olivine phenocrysts and glassy mesostastis by clay minerals and calcite. The significant differences are the variations in alteration degree and the high degree of alteration and partial replacement of plagioclase phenocrysts by clay minerals and sanidine in the plagioclase-phyric pillows of Unit IV. A possible explanation for the high degree of alteration in Unit IV is the presence of significant intercalated carbonate sediments within the pillow lavas. The sediments and their contacts with the pillows may have acted as pathways for low-temperature fluids to percolate through the basalts more easily than in the overlying, more massive units (Subunits IIa-IIc).

The dark gray alteration in Hole U1350A is also comparable to the alteration described for the basalts of the Ontong Java Plateau (OJP) (Mahoney, Fitton, Wallace, et al., 2001; Banerjee et al., 2004). Alteration of the OJP basalts has been interpreted as a result of interaction between basalt and seawater-derived fluids under anoxic-suboxic conditions at low temperature and low water-rock ratios (Banerjee et al., 2004). Differences in alteration mineralogy in Hole U1350A are shown by the relative abundance of calcite replacing olivine phenocrysts and glassy mesostasis, the lack of celadonite, and the widespread occurrence of pyrite, disseminated in the matrix and as constituents of the veins and vesicles.

\section{Structual geology}

Cores recovered from Hole U1350A between 143.10 mbsf in Core 324-U1350A-6R and 315.8 mbsf in Core 324-U1350A-26R contain structures of magmatic, alteration, and deformational origins. The main structural features are represented by pillow structures, veins, and joints. Igneous structures include syn- to late-magmatic structures that are linked to flow, expansion, and contraction of lava.

In the following sections, the characteristics of these structures are described, followed by a description of the distribution and orientations of and relationships between structures. Important observations and interpretations include (1) preferred orientations and contact relations of planar and subplanar structures; (2) variation in structural morphology, such as pattern, size, shape (roundness or sphericity), and vesicles (vesicularity); and (3) crosscutting relationships: primary and secondary structures and structural sequence.

\section{Magmatic flow structures}

Magmatic flow structures are seen both within pillows (intrapillow) and in surrounding rocks (interpillow). They include rotation or plastic strain imposed by the flow of viscous magma. Vesicles are the frozen records of gas bubbles in pillow lavas, which record the pattern of degassing and, once filled with secondary minerals, become amygdules. In Hole U1350A, amygdules are commonly radially oriented within the pillows.

\section{Intrapillow structures Chilled margins}

A chilled margin is one of the major identifiers of pillow structures (Fig. F32). Numerous chilled margins were recovered from pillow lavas in the hole and increase in number with depth. Chilled margins have a typical spheroidal shape, radially aligned vesicles, concentric vesicular zones, radial or network cracking, and a glassy skin (Thorpe and Brown, 1985). Several typical chilled margins are observed in pillow breccia clasts found within hyaloclastic intervals 324-U1350A-19R-2, 11-23 cm; 19R-2, 69-79 cm; and 19R-2, 79-82 cm (Figs. F32, F33). Typical chilled margins in the piled-up pillow sequence can be found in intervals $324-\mathrm{U} 1350 \mathrm{~A}-15 \mathrm{R}-2,92.5-98.5 \mathrm{~cm}$; 20R-1, 100.0-105.5 cm; and 20R-1, 105.5-113.5 cm (Fig. F34).

The estimated size and geometry of pillows inferred by the roundness of chilled margins range from $5 \mathrm{~cm}$ in diameter above Core 324-U1350A-22R to 20-80 $\mathrm{cm}$ in diameter from Cores $22 \mathrm{R}$ through $26 \mathrm{R}$. For example, the curvature of the chilled margins seen on pieces from Core $26 \mathrm{R}$ varies between $30^{\circ}$ and $90^{\circ}$, implying smaller diameter pillows in this hole interval, whereas the curvature of the chilled margins seen on pieces from Core $24 \mathrm{R}$ is lower, ranging between $5^{\circ}$ and $20^{\circ}$, implying their origin from larger diameter pillows. On the other hand, because pillows are seldom ideally round but rather tubelike or elliptical, it cannot be ruled out that the chilled margins of both cores stem from pillows that have similar diameters but are differently oriented within the strata penetrated by the drill hole. However, this assumption appears not very likely. 


\section{Radially aligned and pipe vesicles}

Radially aligned vesicles pointing toward the rim, perpendicular to the chilled margins, can be seen in the pillows throughout the hole (Fig. F34). Pipe vesicles or vesicle cylinders are mainly developed in the central part of larger pillow and sheet flow units, as typically seen in intervals 324-U1350A-12R-1, 36.5$57.0 \mathrm{~cm}$; 13R-1, $13.5-56.5 \mathrm{~cm}$; 14R-2, $13.0-36.5 \mathrm{~cm}$; 17R-1, 79-85 cm; 17R-1, 106-113 cm; and 18R-1, 77$102 \mathrm{~cm}$ (Fig. F35).

\section{Interpillow structures}

Interpillow structures are divided into two types of rocks: hyaloclastic breccias and sedimentary rocks with distinct or weak bedding (Fig. F36). Both are separated by chilled margins from the intrapillow structures, but sometimes we can observe some sediments entering the pillow along fractures. The triangular shape of the sedimentary rock implies the interaction of three pillow rims at interval 324U1350A-26R-4, 69-77 cm. Baked margins of sediment indicate that the basaltic lavas were intruded into the sediments (Fig. F36A). Hyaloclastites in the hole are very dark, brecciated, and glassy in Core 324-U1350A-24R (Fig. F36B) and interval 324U1350A-19R-2, 79-92 cm.

\section{Joints}

Joints are important and frequently found in the lower part of Hole U1350A below Core 324-U1350A22R. Their morphologies are planar, curved, or irregular. They also form complicated arrays including en echelon, parallel, conjugate, radial, and network. Jointing in basalt is often related to three synmagmatic mechanisms: flowing, expansion (inflation), and contraction (cooling) of basalt lava with time (Walker, 1993), and one postmagmatic mechanism, tectonic deformation. The synmagmatic joints are often curved in shape, columnar- or prismaticjointed, or V-shaped. Except for a few curved joints filled with calcite, the geometry of most joints seems to be mainly unrelated to the cracking and cooling of pillow lava. Most joints exhibit no regular distribution or any correlation to pillows or sheet flow morphologies, and their dips do not apparently correlate with rock properties, rock units, or vesicularity (Fig. F37).

\section{Veins}

There are a large number of veins in Hole U1350A. Vein widths are generally $<10 \mathrm{~mm}$, and most are from 0.1 to $\sim 2 \mathrm{~mm}$ wide. Pyrite veins are darker and thinner than calcite veins.
Veins generally form later than joints. Some of them are filled with secondary minerals. As observed for joints, dips of veins are irregular through the hole (Fig. F37). Most veins are formed in the large pillow and sheet flow units. Vein-filling minerals are generally calcite and pyrite. Most pyrite veins are very thin, between 0.1 and $1 \mathrm{~mm}$. A few exceptions, such veins as thick as $2 \mathrm{~mm}$, occur in intervals 324U1350A-16R-1 (Piece 5A) and 17R-1 (Piece 1). Syntaxial vein growths are very common. Calcite-rich veins commonly show polycrystalline fabrics and partly syntaxial or cross-fiber fabrics as well. A few veins show antiaxial fabrics, such as in Thin Section 267 (Sample 324-U1350A-8R-1, 54-58 cm).

Under the microscope, crosscutting relationships can also be found as displacements at vein intersections. The horizontal or subhorizontal veins generally cut the subvertical veins, for example in Thin Sections 287 (Sample 324-U1350A-16R-2, 26-29 cm) and 289 (Sample 324-U1350A-16R-3, 71-74 cm), showing horizontal syntaxial growth of fibrous calcite and vein crosscutting and indicating lateral compression (Fig. F38A, F38B).

The density of veins in the recovered cores is at least 3 veins $/ \mathrm{m}$. Most veins are straight or display planar shape. However, some zigzag veins are also seen in Sections 324-U1350A-22R-4 and 24R-5. Various characteristics of vein arrays are observed, including conjugate or en echelon, parallel, Y-shaped or branched, network, zigzag, and anastomosing veins. Conjugate and en echelon veins are generally closely associated with shear or extensional joints at this site, for example in interval 324-U1350A-22R-5, 92-99 cm. In some samples, veins have splays and intersect others with Y-shaped ends, for example in intervals 324U1350A-22R-5, 78-80 cm, and 22R-5, 104-106 cm. Sometimes both filling minerals and texture change along the vein strike, for example, from calcite to pyrite in mineralogy and from cross-fiber to polycrystalline in filling pattern.

\section{Overall structure}

Based on observations in Hole U1350A, the overall structure of Hole U1350A cores can be separated into two parts by the hyaloclastite (Unit III) of Core 324U1350A-24R: the upper part, characterized by a stacked sheet flow unit with intercalated pillows, and the lower part, characterized by piled-up pillows whose sizes range from $\sim 20$ to $80 \mathrm{~cm}$. Both parts are mainly characterized by synmagmatic pillow structure, including intra- and interpillow structures. In the upper part of the hole, interpillow structures are found in hyaloclastic breccias or calcite fillings. In the lower part, interpillow structures are seen in 
limestones displaying weak bedding. Intrapillow structures throughout the hole are similar in all pillows but differ in size from $\sim 10$ to $\sim 80 \mathrm{~cm}$ in diameter, depending on pillow size. Structural observations were made on thin glassy margins, radially aligned vesicles, concentric vesicular zones, and spheroidal shapes. Synmagmatic structural features are represented by amygdaloidal and vein structures, including vein networks.

The postmagmatic structures include conjugate veins and joints. Dip angles of both veins and joints in the hole show no correlation with depth. However, the number of veins and/or joints is higher in the lower part of the hole (Fig. F39).

\section{Geochemistry}

\section{Major element oxide and trace element analyses}

Forty-three samples of lavas from Hole U1350A were analyzed by inductively coupled plasma-atomic emission spectroscopy for concentrations of major element oxides and several trace elements (see "Geochemistry" in the "Methods" chapter for information on analytical procedures, instrumentation, and data quality). Samples of each of the igneous units recovered (stratigraphic Subunits IIa-IIc and Units III and IV) were included. All were taken from holocrystalline portions of the cores.

As with previous Expedition 324 analyses, total weight percentages of the major element oxides varied substantially (95.20-103.11 wt\%), and we again normalized the measured values to $100 \mathrm{wt} \%$ totals. The normalized data are presented below the measured values in Table T4 and are used in the figures and discussion below. Before proceeding to other results, we note that surprisingly high Ba concentrations of 958 and $734 \mathrm{ppm}$ were obtained for Samples 324-U1350A-17R-1 (Piece 3A, 24-26 cm) and 8R-3 (Piece 10, 81-84 cm), respectively. The other Site U1350 samples contain $\leq 181 \mathrm{ppm}$ of $\mathrm{Ba}$; most have $<80 \mathrm{ppm}$, in common with igneous rocks from other Shatsky Rise drill sites. Except for their anomalously high Ba concentrations, these two samples are not unusual, although their Sr and alkali element contents are elevated slightly. The most likely explanation appears to be contamination of either the powders or solutions by $\mathrm{Ba}$, perhaps by barite-rich drilling mud. However, neither we nor the ship's laboratory staff have any idea how such contamination might have occurred. Unfortunately, too little time remained in the expedition to resample and reanalyze material from these two intervals.
Weight loss on ignition varies from 0.02 to $4.40 \mathrm{wt} \%$ among the Site U1350 samples. This range is similar to that measured for Site U1347 (0.07 to $3.57 \mathrm{wt} \%$ ) and, in general, the chemical effects of alteration again appear relatively modest compared to those at Sites U1346, U1348, and U1349. In a total alkalis versus $\mathrm{SiO}_{2}$ diagram, values for all but five of the Site U1350 samples fall in the field of tholeiitic basalt (Fig. F40). The exceptions appear to reflect $\mathrm{K}_{2} \mathrm{O}$ addition during alteration; in particular, several samples from the highly altered lower part of Unit IV (see "Alteration and metamorphic petrology"), from Section 324-U1350A-25R-8 through Core 324U1350A-26R, have much higher $\mathrm{K}_{2} \mathrm{O}$ concentrations (as high as 3.08 wt\%) (Fig. F41A) than those from shallower parts of the hole. In common with altered samples from other Expedition 324 sites, $\mathrm{Na}_{2} \mathrm{O}$ contents are not elevated significantly in these samples relative to the other Site U1350 rocks, although values for Site U1350 cover a slightly greater total range and, on average, tend to be slightly higher than observed for Site U1347. Much of the $\mathrm{K}_{2} \mathrm{O}$ added to the basalts in the lower part of Hole U1350A is likely to have been incorporated into feldspar, given the partial transformation of plagioclase to sanidine in this portion of the hole (see "Alteration and metamorphic petrology"). Another probable consequence of this transformation is that samples from the deepest part of the hole have the lowest $\mathrm{CaO}$ contents and $\mathrm{CaO} / \mathrm{Al}_{2} \mathrm{O}_{3}$ ratios (Fig. F42A), indicative of Ca loss. Other elements that appear to have been affected to variable extents by alteration throughout the hole include $\mathrm{Mn}$ and possibly Co. Barium contents also may have been modified by alteration; however, interpretation of Ba requires caution. Given the abovementioned possibility of Ba contamination in the two samples with anomalously high Ba contents, lesser amounts of the same type of contamination presumably could have affected other samples. Indeed, even excluding the two highest Ba samples, Ba still varies considerably, between $16 \mathrm{ppm}$ (similar to values in the Site 1213 basalts) and $181 \mathrm{ppm}$. Site U1346 basalts reach the highest Ba levels measured among the sites drilled prior to Site U1350, and as a group, the Site U1346 lavas are more altered than those recovered from Site U1350 (see "Alteration and metamorphic petrology"). However, three Site U1350 samples have greater Ba concentrations than the highest value measured for Site U1346 (93 ppm). Whether affected by alteration or contamination, we do not use Ba in our interpretation of Site U1350 basement geochemistry.

Concentrations of $\mathrm{TiO}_{2}$ vary widely, from 1.31 to $2.51 \mathrm{wt} \%$ (Fig. F42). The range in $\mathrm{Mg} \#$ is also large, 
from 51.1 to $68.5\left(\mathrm{Mg} \#=100 \times \mathrm{Mg}^{2+} /\left[\mathrm{Mg}^{2+}+\mathrm{Fe}^{2+}\right]\right.$, assuming that $\left.\mathrm{Fe}_{2} \mathrm{O}_{3} / \mathrm{FeO}=0.15\right)$. Similar to Sites 1213 and $\mathrm{U} 1347$, the combined $\mathrm{Mg \#}$ and $\mathrm{TiO}_{2}$ data for Site U1350 define an array that largely lies within the field of ocean-ridge basalts and shows only limited overlap with that for OJP basalts (Fig. F42B). The same is true for a number of other elements, such as $\mathrm{Cr}$ (Fig. F42C). At higher concentrations, it is also true for $\mathrm{Zr}$ (Fig. F42D); however, at low $\mathrm{TiO}_{2}$ values the Site U1350 basalts, although still within the ocean-ridge field, have slightly lower $\mathrm{Zr}$ concentrations than most ocean-ridge basalts. Indeed, the $\mathrm{Zr} /$ Ti ratio, a measure of relative incompatible-element enrichment, varies by nearly a factor of 2 overall, from 0.0075 to 0.013 . For comparison, normal $(\mathrm{N}-$ type) and incompatible-element-enriched (E-type) ocean-ridge basalts average $\sim 0.0097$ and $\sim 0.012$, respectively (e.g., Sun and McDonough, 1989). Unlike $\mathrm{Zr}$, Sr concentrations are consistently higher in the Site U1350 samples than in the great majority of ocean-ridge basalts; they also tend to be somewhat higher, for a given value of $\mathrm{TiO}_{2}$, than measured for either Sites 1213 or U1347 (Fig. F42E). This characteristic does not appear to be simply (or solely) an alteration effect (e.g., note the general increase of $\mathrm{Sr}$ with increasing $\mathrm{TiO}_{2}$ ). In contrast, $\mathrm{V}$ contents and $\mathrm{V} /$ Sc ratios tend to be lower than for Site U1347 (e.g., $\mathrm{V} / \mathrm{Sc}=6.3-8.9$ at Site U1350 versus $8.5-11.7$ for all but one Site $\mathrm{U} 1347$ basalt). At $\mathrm{TiO}_{2}$ concentrations greater than $\sim 2 \mathrm{wt} \%, \mathrm{~V}$ contents also are somewhat lower than for the majority of ocean-ridge basalts. Similarly, $\mathrm{Fe}_{2} \mathrm{O}_{3}{ }^{\top}$ (total iron as ferric iron) tends to be lower at a given $\mathrm{TiO}_{2}$ value than in the Site 1213 or $\mathrm{U} 1347$ basalts. Instead, at low $\mathrm{TiO}_{2}(<1.7 \mathrm{wt} \%)$, $\mathrm{Fe}_{2} \mathrm{O}_{3}{ }^{\top}$ values are similar to those measured for basalts from ODP Leg 191 Site 1179 (9.17-11.08 and 9.30-11.17 wt\%, respectively), which represents nonplateau ocean crust formed near Shatsky Rise and during the same period of time.

Interestingly, systematic downhole variations are present for a number of elements. For example, $\mathrm{TiO}_{2}$ concentrations show an overall decrease downhole (Fig. F41B). Correspondingly large downward gradients are seen for $\mathrm{Zr}$ and Sr. Sodium also decreases downhole, whereas Mg\# generally increases with increasing depth (Fig. F41C). These gradients cannot only be a result of systematic variation in the extent of magmatic differentiation. For example, the $\mathrm{Zr} / \mathrm{Ti}$ ratio is relatively insensitive to differentiation (at least prior to removal of magnetite, which is not indicated by the variation of $\mathrm{TiO}_{2}$ versus $\mathrm{Mg \#}$ ), yet $\mathrm{Zr}$ / Ti values markedly decrease downhole (Fig. F41E). As noted above, the highest $\mathrm{Zr} / \mathrm{Ti}$ values are greater than the average for E-type ocean-ridge basalts and the lowest values are less than the average for N-type ocean-ridge basalts. This behavior is indicative of decreasing mean amounts of partial melting with time and/or variation in mantle source composition.

In addition to the general downhole trends throughout the basement section, variability is also evident within the two thickest stratigraphic subunits, IIa and IIc. Some of this variation is consistent with differences in magmatic differentiation, but some is not (e.g., in $\mathrm{Zr} / \mathrm{Ti}$ ). For example, within Subunit IIa, distinct differences in $\mathrm{Cr}, \mathrm{Ni}$, and $\mathrm{Zr} / \mathrm{Ti}$ are present below and above 190 mbsf (e.g., Fig. F41D). A thin, high-Cr (but not high Ni) interval is also present at the top of Subunit IIa; lavas in this interval have low $\mathrm{TiO}_{2}$ and $\mathrm{Zr} / \mathrm{Ti}$ but not particularly high (or low) $\mathrm{Mg \# .}$

Overall, the Site U1350 basalts encompass the greatest range of chemical variation seen at any individual Shatsky Rise drill site. Careful work onshore is required to decipher the relative roles of magmatic differentiation, partial melting, and mantle source composition in producing this variation.

\section{Physical properties}

Igneous and sedimentary rocks from Hole U1350A were characterized for physical properties as described in "Physical properties" in the "Methods" chapter. Forty-three (42 igneous and 1 limestone) discrete oriented cubic samples were cut from the working half of the cores for measurement of moisture and density properties as well as compressional $(P$-wave) velocities in three directions. No measurements of thermal conductivity were made at this site because of technical difficulties with the instrument.

\section{Whole-Round Multisensor Logger measurements}

\section{Magnetic susceptibility}

Results for whole-round magnetic susceptibility for Hole U1350A are summarized in Figure F43. Magnetic susceptibility decreases downhole. The uppermost Subunit IIa, made of massive basalt flows and pillowlike inflation units (see "Igneous petrology"), averages $1357 \pm 723 \times 10^{-5}$ SI $(2 \sigma)$. Subunit IIa also contains three excursions to values $>2000 \times 10^{-5} \mathrm{SI}$, occurring in Sections 324-U1350A-7R-1, $50 \mathrm{~cm}(2272$ $\left.\times 10^{-5} \mathrm{SI}\right), 9 \mathrm{R}-3,61 \mathrm{~cm}\left(2268 \times 10^{-5} \mathrm{SI}\right)$, and 11R-2, 56 $\mathrm{cm}\left(2370 \times 10^{-5} \mathrm{SI}\right)$. Magnetic susceptibility remains fairly high throughout the basaltic transition of Subunit IIb (from massive inflation units to smaller pillow units; see "Igneous petrology"), with values averaging $1308 \pm 568 \times 10^{-5}$ SI $(2 \sigma)$. Subunit IIc is 
described as pillow basalts (see "Igneous petrology"); however, it can clearly be split into two intervals based on magnetic susceptibility. The upper interval found in Core 324-U1350A-20R from 249.54 to 262.06 mbsf maintains a high magnetic susceptibility value averaging $1407 \pm 296 \times 10^{-5}$ SI $(2 \sigma)$, whereas material in the remainder of the unit from Cores 22R through 24R (268.96-290.30 mbsf) shows a sharp $\sim 50 \%$ decrease in magnetic susceptibility to average values of $725 \pm 431 \times 10^{-5}$ SI $(2 \sigma)$. The transition to lower magnetic susceptibility corresponds to the end of intercalated sediment and pillows and the onset of a continuous pillow stack devoid of sediments (see "Igneous petrology"). However, since magnetic susceptibility values remain low downhole (see next paragraph) when sedimentary interbeds return, a correlation cannot be made directly with lithology.

Hyaloclastic material composing Unit III (see "Igneous petrology") yields very few data that are not affected by cracks/edge effects (see "Physical properties" in the "Methods" chapter). The unit (290.36296.78 mbsf; Sections 324-U1350A-24R-3 through 25R-1) is pervasively cracked and/or rubbly. Therefore, it is difficult to assess characteristic values of this unit with whole-round magnetic susceptibility measurements. Averaging filtered data yields a value of $266 \pm 474 \times 10^{-5} \mathrm{SI}(2 \sigma)$, which is an underestimation (see details on filtered data maxima in "Physical properties" in the "Methods" chapter). Unit IV consists of pillow basalts presumably intruded into limestone (see "Igneous petrology" and "Sedimentology"). Unit IV displays low magnetic susceptibility values similar to the lower interval of pillow basalts seen in Subunit IIc, with an average of $623 \pm$ $475 \times 10^{-5}$ SI $(2 \sigma)$. Unit IV has been subjected to higher alteration, perhaps accounting for some of the decrease in magnetic susceptibility.

\section{Gamma ray attenuation bulk density}

The results for gamma ray attenuation (GRA) bulk density measurements are summarized in Figure F43. Filtering of data does not take into account the differences between recovered core diameter and a full core liner diameter so that the GRA data may still include some artificially low values (Fig. F43); therefore, averages of the filtered bulk density should be considered an underestimate. Overall, density maxima remain fairly constant downhole at $\sim 2.5 \mathrm{~g} / \mathrm{cm}^{3}$, irrespective of unit.

\section{Natural Gamma Ray Logger}

Measurement of natural gamma radiation (NGR) is summarized in Figure F43. Counts per second of
NGR in Hole U1350A ranged from 2 to $15 \mathrm{cps}$. Stratigraphic units can be somewhat distinguished by their NGR values. Overall, Subunit IIa (massive basalt flows; see "Igneous petrology") has an average NGR signal of $4.05 \pm 3.94 \mathrm{cps}(2 \sigma)$. Upon further examination, Subunit IIa can be divided into two intervals based on NGR readings. The upper part of the unit found in Cores 324-U1350A-7R through 10R has counts between 2 and $10 \mathrm{cps}$, whereas the lower interval in Cores $11 \mathrm{R}$ through $16 \mathrm{R}$ show a decrease in NGR counts to $2-5$ cps. The NGR signal in both the upper and lower part of the unit is due to products of the ${ }^{40} \mathrm{~K}$ decay chain, as observed in gamma spectra. The increased ${ }^{40} \mathrm{~K}$ signal could be due to alteration clays, increased plagioclase abundance, or some combination thereof. The basaltic transition (see "Igneous petrology") in Subunit IIb has a uniform NGR signal with an average of $3.46 \pm 2.47 \mathrm{cps}$ $(2 \sigma)$. The low NGR counts continue through the underlying Subunit IIc, consisting of pillow basalts (see "Igneous petrology") and displaying an average of $2.51 \pm 1.62$ cps $(2 \sigma)$.

The hyaloclastic material in Unit III (see "Igneous petrology") has a slightly increased NGR signal, averaging $3.92 \pm 2.4 \mathrm{cps}(2 \sigma)$ and showing excursions up to 7 cps. Finally, the lowermost recovered Unit IV of intercalated pillow basalts and limestones yields the highest NGR values in Hole U1350A, with an average of $6.86 \pm 4.95 \mathrm{cps}(2 \sigma)$, reaching values of 15 cps. The higher counts are attributed to products of the ${ }^{40} \mathrm{~K}$ decay chain, and not, for example, uranium derived from the sedimentary material. The increased ${ }^{40} \mathrm{~K}$ decay chain NGR counts in this lower unit are consistent with indications that this section of the hole is more altered than the overlying material (see "Alteration and metamorphic petrology").

\section{Moisture and density}

Table T5 summarizes discrete sample bulk density, dry density, grain density, void ratio, water content, and porosity. Figure F44 shows the downhole variation of bulk density, dry density, and grain density, as well as porosity. Discrete determinations confirm the consistent downhole bulk density inferred from the maximum GRA density measurements (Fig. F43). Discrete measurements of bulk density are also plotted on Figure F43. The average bulk density for the entire hole is $2.61 \pm 0.17 \mathrm{~g} / \mathrm{cm}^{3}(2 \sigma)$ with averages from all individual units within error of this value. The single limestone discrete sample (Section 324U1350A-26R-5) has indistinguishable density compared to the surrounding basalts from the same unit.

Porosity varies throughout the hole and is controlled by the vesicularity of the material rather than dis- 
tinction between stratigraphic units. In general, porosity ranges from $3.43 \%$ to $28.45 \%$ and shows a good negative correlation with bulk density (Fig. F44). The limestone sample displays half the porosity of the surrounding basalts of Unit IV $(8.6 \%$ versus $13 \%-15 \%)$.

\section{Compressional ( $P$-wave) velocity}

Compressional wave velocities of discrete samples measured in Hole U1350A are shown in Figure F44, and data are listed in Table T6. All samples show no appreciable anisotropy and have an average of 4.793 $\pm 1.249 \mathrm{~km} / \mathrm{s}(2 \sigma)$. In analogous fashion to porosity, the $P$-wave velocity is controlled by amount of vesicles, rather than distinction due to stratigraphic unit, consistent with the low variation of downhole bulk density. The sample set includes one limestone from Unit IV (Section 324-U1350A-26R-5) that has an indistinguishable $P$-wave velocity $(5.585 \mathrm{~km} / \mathrm{s})$ from the surrounding basaltic samples taken from the same unit. This value is remarkably high for limestone and might be due to the variable baking the material has undergone (see "Sedimentology").

Figure F45A illustrates the positive correlation between $P$-wave velocity and bulk density measurements. There is some scatter evident in the figure. In particular, samples from Sections 324-U1350A-16R$1,26 \mathrm{R}-1$, and 26R-5 lie significantly off the trend. The sample from Section 26R-5 is limestone, so it is not necessarily expected to fall on the same regression as basaltic material. The sample from Section 26R-1 is a mixture of alteration clay and basaltic material, which makes its physical properties distinct from homogeneous igneous material. The sample from Section 16R-1 has an anomalously low density for its $P$-wave value. Upon examination, the sample was highly vesicular. However, some of the vesicles were in-filled with dark clay material, perhaps allowing for a lower density while maintaining a higher $P$ wave velocity.

Figure F45B shows the negative correlation between $P$-wave velocity and porosity. There is one outlier in the figure from Section 16R-1 that has an anomalously high porosity for its measured $P$-wave velocity. As with the bulk density, this may be related to the abundance of vesicles and their secondary in-filling.

\section{Paleomagnetism}

We measured and analyzed 42 discrete basalt samples $\left(7 \mathrm{~cm}^{3}\right)$ from various lithologies downhole (Table T7). Their bulk magnetic susceptibilities are on the order of $10^{-2}$ SI. Eighteen samples were alternating-field demagnetized up to $140 \mathrm{mT}$ in steps of 2, 5, or $10 \mathrm{mT}$ up to fields between 80 and $150 \mathrm{mT}$, and twenty-four were thermally demagnetized in steps of $50^{\circ}$ or $25^{\circ} \mathrm{C}$ up to temperatures between $550^{\circ}$ and $600^{\circ} \mathrm{C}$. Magnetic susceptibility was measured after each heating step in order to detect possible mineralogical changes.

Most natural remanent magnetization measurements and first demagnetization steps show a steep vertical component, typical of drilling overprint (e.g., Audunsson and Levi, 1989; Wilson, Teagle, Acton, et al., 2003). This drilling overprint is usually erased at $\sim 10 \mathrm{mT}$ or $100^{\circ} \mathrm{C}$ (Fig. F46).

\section{Working-half discrete sample measurements}

\section{Alternating-field demagnetization}

The demagnetization behavior of the samples can be classified into two types. The first type, observed in samples from Sections 324-U1350A-7R-1 through $24 \mathrm{R}-3$, is characterized by low coercivity, suggested by median destructive fields $<10 \mathrm{mT}$. These samples also have a magnetization that decays exponentially (e.g., Sample 324-U1350A-21R-2, 67-69 cm) (Fig. F46A), indicating the presence of multidomain grains as magnetization carriers (Argyle et al., 1994). The second type of demagnetization behavior is observed in samples from Sections 25R-2 through 26R1 (corresponding to stratigraphic Unit IV plagioclasephyric pillow succession; see "Igneous petrology"). This second type of behavior is characterized by an initial plateau on the demagnetization spectra, which could indicate that the magnetization carriers are single-domain grains (Argyle et al., 1994) (e.g., Sample 324-U1350A-26R-1, 78-80 cm) (Fig. F46B). Inclinations of these samples were calculated using principal component analyses (Kirschvink, 1980). All the samples show a very stable univectorial decay toward the origin of orthogonal vector plots after the removal of overprints at $7-10 \mathrm{mT}$ (Fig. F46), with maximum angular deviation values $<5^{\circ}$ for all samples and $<2^{\circ}$ for 16 out of 18 samples. The resulting inclinations are dominantly shallow but quite scattered (between $-12^{\circ}$ and $14^{\circ}$ ), with one anomalously high value $\left(27^{\circ}\right)$ in Sample 324-U1350A-12R-1, 50$52 \mathrm{~cm}$.

\section{Thermal demagnetization}

Thermal demagnetization spectra show that magnetization decreases gradually with temperature. This suggests a large distribution of unblocking temperatures, which indicates a large distribution of Ti content in the titanomagnetite (-maghemite), the most likely carrier of the magnetization (Hunt et al., 1994). In some cases, the magnetization decrease 
starts from the very first demagnetization step and most of the sample is demagnetized by $400^{\circ} \mathrm{C}$ (e.g., Sample 324-U1350A-18R-1, 97-99 cm) (Fig. F46C). In the majority of cases, however, the main magnetization decrease occurs over two steps: one broad step at $\sim 400^{\circ} \mathrm{C}$ and another sharper step at $500^{\circ} \mathrm{C}$ (e.g., Sample 324-U1350A-21R-1, 35-37 cm) (Fig. F46D). This two-step decrease indicates that several phases are present: a Ti-poor phase (close to pure magnetite) and a Ti-rich phase with a distribution of Ti content. A partial self-reversal of magnetization at $\sim 300^{\circ} \mathrm{C}$ might be occurring in several samples from Sections 324-U1350A-16R-1 through 21R-1 (e.g., Sample 324U1350A-16R-1, 35-37 cm) (Fig. F46E). In these samples, we observe an increase of the magnetization during the demagnetization procedure at $\sim 300^{\circ} \mathrm{C}$, and the direction corresponding to this temperature step is antipodal to the direction of the primary remanent magnetization. Such behavior is not uncommon in submarine basalts (e.g., Dubrovine and Tarduno, 2004). Only five thermal demagnetizations did not allow the definition of a primary magnetization component pointing toward the origin of the orthogonal vector plot. The other 19 samples gave scattered inclination values between $-31^{\circ}$ and $31^{\circ}$ and very small maximum angular deviation values $\left(<4^{\circ}\right)$ in the majority of cases.

The variation of bulk magnetic susceptibility with temperature displays two main behaviors. For Sections 324-U1350A-7R-1 through 23R-2, the susceptibility increases at $\sim 350^{\circ} \mathrm{C}$ to twice its room-temperature value, then decreases, and returns to roomtemperature value by $500^{\circ}-600^{\circ} \mathrm{C}$. This could indicate the inversion of the primary titanomaghemite into magnetite (Özdemir and O'Reilly, 1982), which alters even more with further heating.

For Sections 24R-1 through 26R-8, magnetic susceptibility starts decreasing at $\sim 400^{\circ} \mathrm{C}$ and then increases sharply at $\sim 550^{\circ} \mathrm{C}$, suggesting that the magnetic mineralogy in this part of the core is different from that of the previous part.

\section{Directional study}

Igneous lithology observed in Hole U1350A is composed of piles of thin massive inflated lavas and alternating layers of pillow lavas and baked interpillow sediments (limestone). The igneous basement in Hole U1350A was divided into five igneous units (see "Igneous petrology"). Average inclinations, calculated for samples with maximum angular deviation $<8^{\circ}$, are: $6.2^{\circ} \pm 15.6^{\circ}, 15.9^{\circ} \pm 9.3^{\circ}, 6.6^{\circ} \pm 10.7^{\circ}$, and $1.1^{\circ} \pm 6.3^{\circ}$ for Subunits IIa, IIb, and IIc and Unit IV, respectively. The large error bars $(1 \sigma)$ show that the calculated downhole inclinations are quite scattered within each igneous lithology (Fig. F47). This scatter is larger than in other holes. Moreover, the average inclinations for the four units are not statistically different from one another. More inclination measurements are needed in order to interpret the directional results of Hole U1350A.

\section{Downhole logging Operations}

A wiper trip was completed throughout the open hole, and the RCB bit was released at the bottom of the hole using the mechanical bit release before the start of the wireline logging operations. The hole was displaced using $90 \mathrm{bbl}$ of barite mud, and the drill pipe was set at a depth of $4184 \mathrm{~m}$ DRF. Logging operations in Hole U1350A consisted of two attempts to deploy one tool string and took place in deteriorating weather with initial ship heave conditions of $\sim 2$ $\mathrm{m}$, which gradually changed to $\sim 4 \mathrm{~m}$ peak to peak heave and wind gusts of up to $56 \mathrm{kt}$. Downhole logging operations began at $0510 \mathrm{~h}$ on 19 October 2009 and were concluded at $0030 \mathrm{~h}$ on 20 October after the tool string was rigged down.

\section{Tool string deployment HNGS-APS-HLDS-DITE}

The wireline tool string deployment consisted of a $29 \mathrm{~m}$ long triple combo tool string that included a logging equipment cable head, digital telemetry cartridge, Hostile Environment Natural Gamma Ray Sonde (HNGS), Hostile Environment Natural Gamma Ray Cartridge, Accelerator Porosity Sonde (APS), Litho-Density Sonde Cartridge, Hostile Environment Litho-Density Sonde (HLDS), digital telemetry adapter, and Digital Dual Induction Tool model $\mathrm{E}$ (DITE). The tool string was lowered to $3600 \mathrm{~m} \mathrm{DRF}$ at a speed of $\sim 2200 \mathrm{~m} / \mathrm{h}$. At this depth, the head tension decreased dramatically and the cable speed was reduced to $\sim 90-120 \mathrm{~m} / \mathrm{h}$ to avoid potential damage to the wireline. The slow progress required pumping pressure down the drill pipe to aid the descent and 10-15 strokes/min at 100 psi was pumped to help push the tool string down. Initial improvement was observed, but at $\sim 4000 \mathrm{~m} \mathrm{DRF}$, the progress slowed again and the ship's heave increased to $\sim 3 \mathrm{~m}$ peak to peak, which significantly increased tension changes both at the surface and downhole. At this depth, the normal tool weight of $1200 \mathrm{lb}$ could not be picked up, and the tool weight in fluid was $\sim 300-500 \mathrm{lb}$, dipping to below $0 \mathrm{lb}$ with heave. At this point, a decision was made to pull out of the hole to check the cable and tools as a precaution and to consider rigging down and pumping with high pressure with the tools out of the hole. The radioactive source was removed, the tool string was rigged down, and the 
high-pressure lines were attached to the top of the drill pipe. An initial pressure of 1000 psi was applied and the pressure dropped to $800 \mathrm{psi}$, potentially indicating a restriction had cleared. Pump pressure was increased to 1600 psi and 2500 strokes of seawater was pumped for $\sim 30 \mathrm{~min}$ to make sure any potential mud was cleared of the pipe.

\section{HNGS-HLDS-DITE}

The second attempt to deploy the tool string was performed without the APS to reduce the potential drag from the APS bowspring. This wireline tool string was $22 \mathrm{~m}$ long. The radioactive source was installed, and tools were run in the hole by $1400 \mathrm{~h}$ on 19 October. During rig up, the weather conditions deteriorated to $\sim 56 \mathrm{kt}$ winds and $4 \mathrm{~m}$ peak to peak heave. The second tool string descent slowed again as the head tension decreased at $~ 3600$ m DRF. Pump pressure was used again, and initially it appeared to help the tool string's descent. The increased heave conditions during this descent caused surface tension fluctuations of 2000-3000 lbf, with a maximum of slightly $>8000 \mathrm{lbf}$ and small fluctuations on the downhole head tension. From 4000 to $4122 \mathrm{~m} \mathrm{DRF}$ (Fig. F48), the head tension was an average of $0 \mathrm{lbf}$, and after the pumps were turned off, the head tension decreased to between -200 and $-300 \mathrm{lbf}$. Several possibilities were discussed on the cause of the problem with no clear answer for what was causing the apparent decrease in downhole head tension. The heave and tension fluctuations made going into open hole a very risky decision, particularly with the pipe potentially being able to sever the wireline if the wireline had slacked conditions near the end of the pipe. Because time was running out and without knowing for sure whether the low-tension problem was caused by a heavy mud buildup inside pipe or a possible logging head load cell problem, it was decided terminate the logging operations.

The tool string was brought back to surface, the radioactive source was offloaded, and the individual tools were safely rigged down without any note of physical damage to tools or wireline. The bottomhole assembly (BHA) and pipe were later brought to surface and no anomalies were noted. Preliminary assessments of the downhole data show a significant decrease in head tension beginning at $\sim 3200 \mathrm{~m} \mathrm{DRF}$ and having significant negative values below $4000 \mathrm{~m}$ DRF (Fig. F48). The cable head was tested postcruise and the results show temperature- and pressure-dependent problems caused an erroneous decrease in head tension.

\section{Preliminary results}

The downlog inside the BHA recorded seafloor at 4074 meters below rig floor, which is $7 \mathrm{~m}$ deeper than the drillers seafloor depth, and $\sim 27.7 \mathrm{~m}$ of the shallow sediments (Fig. F49). The gamma ray measurements in the shallow sediments show an anomaly from seafloor to $\sim 25 \mathrm{~m}$ wireline matched depth below seafloor. The contributions to this anomaly are mainly an increase in Th and a smaller contribution from U (Fig. F49).

\section{References}

Alt, J.C., 1995. Subseafloor processes in mid-ocean ridge hydrothermal systems. In Humphris, S.E., Zierenberg, R., Mullineaux, L., and Thomson, R. (Eds.), Seafloor Hydrothermal Systems: Physical, Chemical, Biological and Geological Interactions within Hydrothermal Systems. Geophys. Monogr., 91:85-114.

Alt, J.C., 2004. Alteration of the upper oceanic crust: mineralogy, chemistry, and processes. In Elderfield, H., and Davis, E. (Eds.), Hydrogeology of the Oceanic Lithosphere: New York (Cambridge Univ. Press), 456-488.

Argyle, K.S., Dunlop, D.J., and Xu, S., 1994. Single domain behavior of multidomain magnetite grains. Eos, Trans. Am. Geophys. Union, 75(44)(Suppl.):196. (Abstract)

Audunsson, H., and Levi, S., 1989. Drilling-induced remanent magnetization in basalt drill cores. Geophys. J. Int., 98(3):613-622. doi:10.1111/j.1365-

246X.1989.tb02294.x

Bach, W., Hegner, E., Erzinger, J., and Satir, M., 1994. Chemical and isotopic variations along the superfast spreading East Pacific Rise from 6 to $30^{\circ}$ S. Contrib. Mineral. Petrol., 116(4):365-380. doi:10.1007/BF00310905

Banerjee, N.R., Honnorez, J., and Muehlenbachs, K., 2004. Low-temperature alteration of submarine basalts from the Ontong Java Plateau. In Fitton, J.G., Mahoney, J.J., Wallace, P.J., and Saunders, A.D. (Eds.), Origin and Evolution of the Ontong Java Plateau. Geol. Soc. Spec. Publ., 229(1):259-273. doi:10.1144/GSL.SP.2004.229.01.15

Batiza, R., and White, J.D.L., 2000. Submarine lavas and hyaloclastite. In Sigurdsson, H., Houghton, B.F., McNutt, S.R., Rymer, H., and Stix, J. (Eds.), Encyclopedia of Volcanoes: San Diego (Acad. Press), 361-381.

Doubrovine, P.V., and Tarduno, J.A., 2005. On the compositional field of self-reversing titanomaghemite: constraints from Deep Sea Drilling Project Site 307. J. Geophys. Res., [Solid Earth], 110(B11):B11104. doi:10.1029/2005JB003865

Fisher, R.V., 1960. Classification of volcanic breccias. Geol. Soc. Am. Bull., 71(7):973-982. doi:10.1130/00167606(1960)71[973:COVB]2.0.CO;2

Fitton, J.G., and Godard, M., 2004. Origin and evolution of magmas on the Ontong Java Plateau. In Fitton, J.G., Mahoney, J.J., Wallace, P.J., and Saunders, A.D. (Eds.), 
Origin and Evolution of the Ontong Java Plateau. Geol. Soc. Spec. Publ., 229(1):151-178. doi:10.1144/

GSL.SP.2004.229.01.10

Gregg, T.K.P., and Fink, J.H., 1995. Quantification of submarine lava-flow morphology through analog experiments. Geology, 23(1):73-76. doi:10.1130/ 0091-7613(1995)023<0073:QOSLFM>2.3.CO;2

Honnorez, J., 2003. Hydrothermal alteration vs. oceanfloor metamorphism. A comparison between two case histories: the TAG hydrothermal mound (Mid-Atlantic Ridge) vs. DSDP/ODP Hole 504B (Equatorial East Pacific). C. R. Geosci., 335(10-11):781-824. doi:10.1016/j.crte.2003.08.009

Hunt, C.P., Moskowitz, B.M., and Banerjee, S.K., 1995. Magnetic properties of rocks and minerals. In Ahrens, T.J. (Ed.), Rock Physics and Phase Relations: A Handbook of Physical Constants. Am. Geophys. Union Ref. Shelf, 3:189-204.

Jerram, D.A., Cheadle, M.J., and Philpotts, A.R., 2003. Quantifying the building blocks of igneous rocks: are clustered crystal frameworks the foundation? J. Petrol., 44(11):2033-2051. doi:10.1093/petrology/egg069

Kirkpatrick, R.J., 1979. Processes of crystallization in pillow basalts, Hole 396B, DSDP Leg 46. In Dmitriev, L., Heirtzler, et al., 1979. Init. Repts. DSDP, 46: Washington, DC (U.S. Govt. Printing Office), 271-282. doi:10.2973/ dsdp.proc.46.117.1979

Kirschvink, J.L., 1980. The least-squares line and plane and the analysis of palaeomagnetic data. Geophys. J. R. Astron. Soc., 62(3):699-718. doi:10.1111/j.1365246X.1980.tb02601.x

Klaus, A., and Sager, W.W., 2002. Data report: high-resolution site survey seismic reflection data for ODP Leg 198 drilling on Shatsky Rise, northwest Pacific. In Bralower, T.J., Premoli Silva, I., Malone, M.J., et al., Proc. ODP, Init. Repts., 198: College Station, TX (Ocean Drilling Program), 1-21. doi:10.2973/odp.proc.ir.198.111.2002

Kokelaar, B.P., 1982. Fluidization of wet sediments during the emplacement and cooling of various igneous bodies. J. Geol. Soc., 139(1):21-33. doi:10.1144/ gsigs.139.1.0021

Le Maitre, R.W., Bateman, P., Dudek, A., Keller, J., Lameyre, J., Le Bas, M.J., Sabine, P.A., Schmid, R., Sorensen, H., Streckeisen, A., Woolley, A.R., and Zanettin, B., 1989. A Classification of Igneous Rocks and Glossary of Terms: Oxford (Blackwell).

Macdonald, G.A., 1968. Composition and origin of Hawaiian lavas. In Coats, R.R., Hay, R.L., and Anderson, C.A. (Eds.), Studies in Volcanology-A Memoir in Honor of Howel Williams. Mem.-Geol. Soc. Am., 116:477-522.

Macdonald, G.A., and Katsura, T., 1964. Chemical composition of Hawaiian lavas. J. Petrol., 5(1):82-133.

Mahoney, J.J., Fitton, J.G., Wallace, P.J., et al., 2001. Proc. ODP, Init. Repts., 192: College Station, TX (Ocean Drilling Program). doi:10.2973/odp.proc.ir.192.2001

Mahoney, J.J., Sinton, J.M., Kurz, M.D., Macdougall, J.D., Spencer, K.J., and Lugmair, G.W., 1994. Isotope and trace element characteristics of a super-fast spreading ridge: East Pacific Rise $13-23^{\circ}$ S. Earth Planet. Sci. Lett.,
121(1-2):173-193. doi:10.1016/

0012-821X(94)90039-6

McPhie, J., Doyle, M., and Allen, R., 1993. Volcanic Textures: A Guide to the Interpretation of Textures in Volcanic Rocks: Hobart (Tasmanian Govt. Printing Office).

Moore, J.G., 1975. Mechanism of formation of pillow lava. Am. Sci., 63(3):269-277.

Nakanishi, M., Sager, W.W., and Klaus, A., 1999. Magnetic lineations within Shatsky Rise, northwest Pacific Ocean: implications for hot spot-triple junction interaction and oceanic plateau formation. J. Geophys. Res., [Solid Earth], 104(B4):7539-7556. doi:10.1029/1999JB900002

Natland, J.H., 1979. Crystal morphologies in basalts from DSDP Site $395,23^{\circ} \mathrm{N}, 46^{\circ} \mathrm{W}$, Mid-Atlantic Ridge. In Melson, W.G., Rabinowitz, P.D., et al., Init. Repts. DSDP, 45: Washington, DC (U.S. Govt. Printing Office), 423-445. doi:10.2973/dsdp.proc.45.118.1979

Natland, J.H., 1980. Crystal morphologies in basalts dredged and drilled from the East Pacific Rise near $9^{\circ} \mathrm{N}$ and the Siqueiros Fracture Zone. In Rosendahl, B.R., Hekinian, R., et al., Init. Repts. DSDP, 54: Washington, DC (U.S. Govt. Printing Office), 605-634. doi:10.2973/ dsdp.proc.54.124.1980

Ogg, J.G., Ogg, G., and Gradstein, F.M., 2008. The Concise Geologic Time Scale: Cambridge (Cambridge Univ. Press). http://www.cambridge.org/catalogue/catalogue.asp?isbn=9780521898492

Özdemir, Ö., and O’Reilly, W., 1982. Magnetic hysteresis properties of synthetic monodomain titanomaghemites. Earth Planet. Sci. Lett., 57(2):437-447. doi:10.1016/0012-821X(82)90162-5

Sager, W.W., Kim, J., Klaus, A., Nakanishi, M., and Khankishieva, L.M., 1999. Bathymetry of Shatsky Rise, northwest Pacific Ocean: implications for ocean plateau development at a triple junction. J. Geophys. Res., [Solid Earth], 104(4):7557-7576. doi:10.1029/1998JB900009

Sandwell, D.T., and MacKenzie, K.R., 1989. Geoid height versus topography for oceanic plateaus and swells. $J$. Geophys. Res., [Solid Earth], 94:7403-7418. doi:10.1029/ JB094iB06p07403

Shipboard Scientific Party, 2002. Leg 198 summary. In Bralower, T.J., Premoli Silva, I., Malone, M.J., et al., Proc. ODP, Init. Repts., 198: College Station, TX (Ocean Drilling Program), 1-148. doi:10.2973/

odp.proc.ir.198.101.2002

Sinton, J.M., Smaglik, S.M., Mahoney, J.J., and Macdonald, K.C., 1991. Magmatic processes at superfast spreading mid-ocean ridges: glass compositional variations along the East Pacific Rise $13^{\circ}-23^{\circ} \mathrm{S}$. J. Geophys. Res., [Solid Earth], 96:6133-6155. doi:10.1029/90JB02454

Smith, W.H.F., and Sandwell, D.T., 1997. Global sea floor topography from satellite altimetry and ship depth soundings. Science, 277(5334):1956-1962. doi:10.1126/ science.277.5334.1956

Sun, S.-S., and McDonough, W.F., 1989. Chemical and isotopic systematics of oceanic basalts: implications for mantle composition and processes. In Saunders, A.D., and Norry, M.J. (Eds.), Magmatism in the Ocean Basins. 
Geol. Soc. Spec. Publ., 42(1):313-345. doi:10.1144/ GSL.SP.1989.042.01.19

Tejada, M.L.G., Mahoney, J.J., Duncan, R.A., and Hawkins, M.P., 1996. Age and geochemistry of basement and alkalic rocks of Malaita and Santa Isabel, Solomon Islands, southern margin of Ontong Java Plateau. J. Petrol. 37(2):361-394. doi:10.1093/petrology/37.2.361

Tejada, M.L.G., Mahoney, J.J., Neal, C.R., Duncan, R.A., and Petterson, M.G., 2002. Basement geochemistry and geochronology of Central Malaita, Solomon Islands, with implications for the origin and evolution of the Ontong Java Plateau. J. Petrol., 43(3):449-484. doi:10.1093/petrology/43.3.449

Thorpe, R.S., and Brown, G.C., 1985. Geological Society of London Handbook: The Field Description of Igneous Rocks: Milton Keynes, U. K. (Open Univ. Press)
Walker, G.P.L., 1992. Morphometric study of pillow-size spectrum among pillow lavas. Bull. Volcanol., 54(6):459474. doi:10.1007/BF00301392

Walker, G.P.L., 1993. Mantle and magmatic processes: basaltic-volcano systems. Geol Soc. Spec. Publ., 76(1):338. doi:10.1144/GSL.SP.1993.076.01.01

Wilson, D.S., Teagle, D.A.H., Acton, G.D., et al., 2003. Proc. ODP, Init. Repts., 206: College Station, TX (Ocean Drilling Program). doi:10.2973/odp.proc.ir.206.2003

Yamagishi, H., 1985. Growth of pillow lobes-evidence from pillow lavas of Hokkaido, Japan, and North Island, New Zealand. Geology, 13(7):499-502. doi:10.1130/ 0091-7613(1985)13<499:GOPLFP>2.0.CO;2

Publication: 3 November 2010 MS 324-107 
Figure F1. Bathymetry of Ori Massif and location of Sites U1349 and U1350. Contours and colors indicate bathymetric depths predicted by satellite altimetry (Smith and Sandwell, 1997). Contours shown at $200 \mathrm{~m}$ intervals; dark contours shown for kilometer multiples. Red line $=$ track of Cruise TN037 site survey (Klaus and Sager, 2002). Site 1208 was cored during ODP Leg 198. See the "Expedition 324 summary" chapter for details).

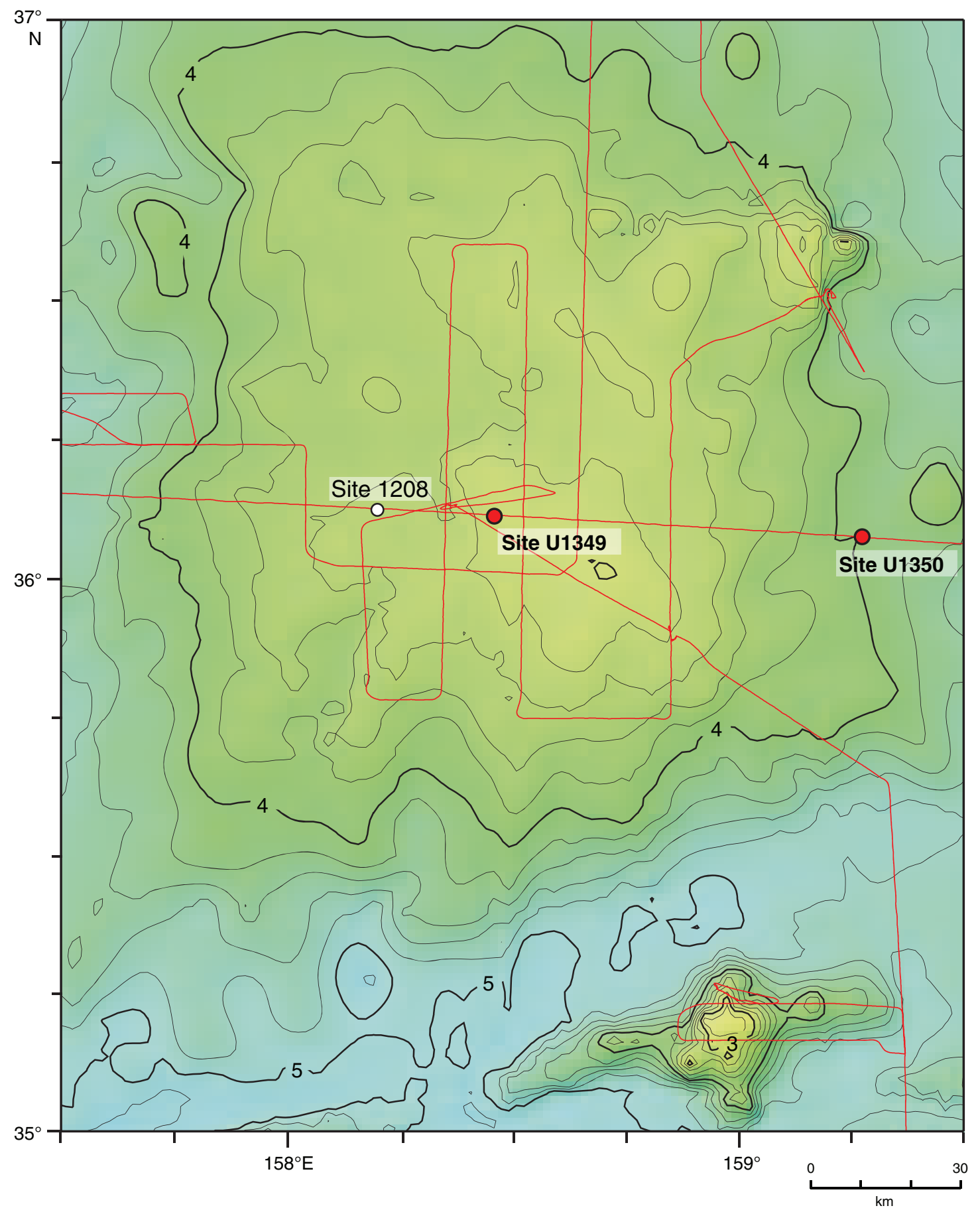


Figure F2. Seismic section and precruise layer interpretation (color overlay), Site U1350. See Klaus and Sager (2002).

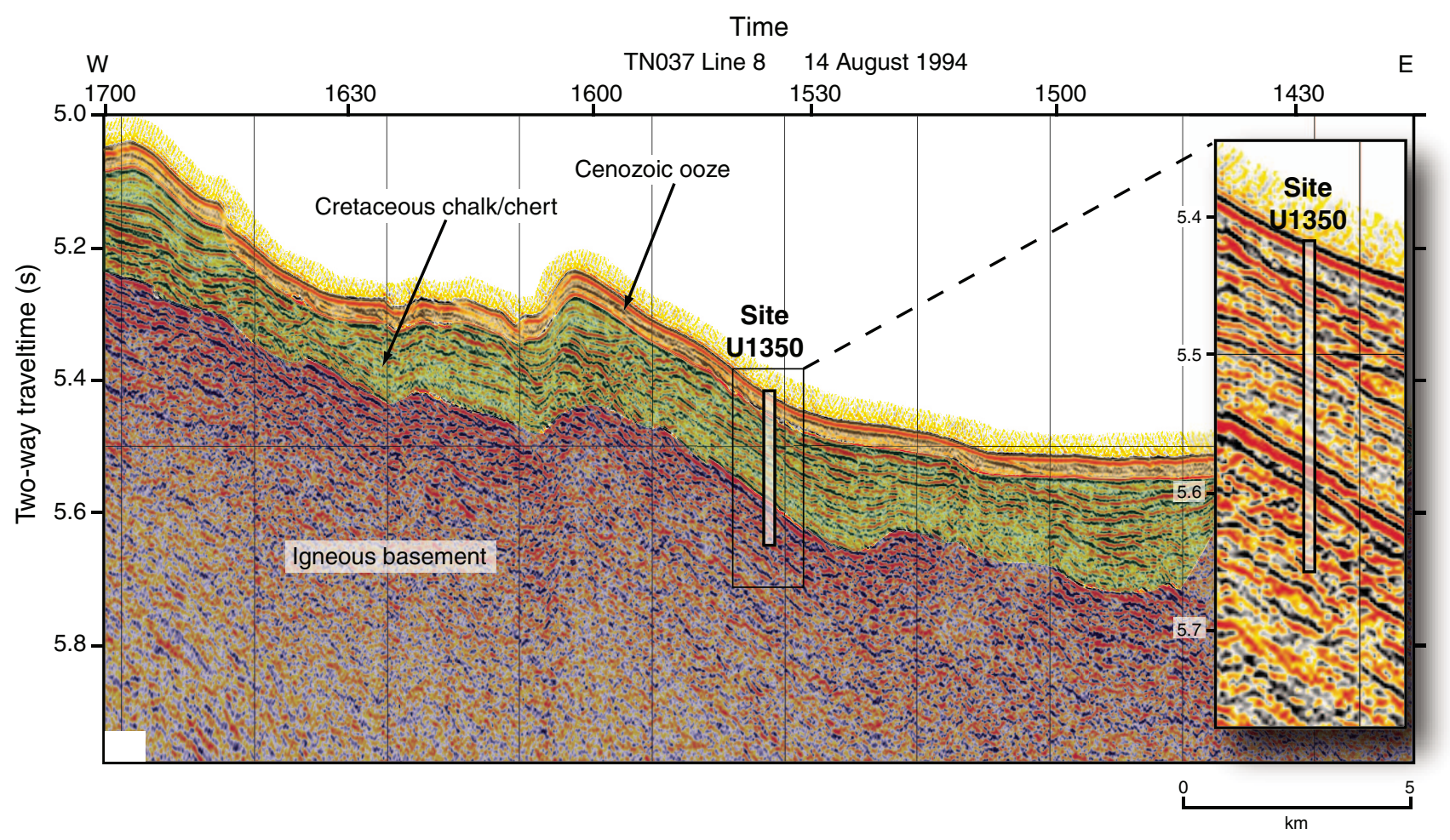


Figure F3. Plot of operation time vs. penetration depth, Hole U1350A. Dashed line = planned penetration progress, solid blue line $=$ actual depth achieved. $\mathrm{RCB}=$ rotary core barrel.

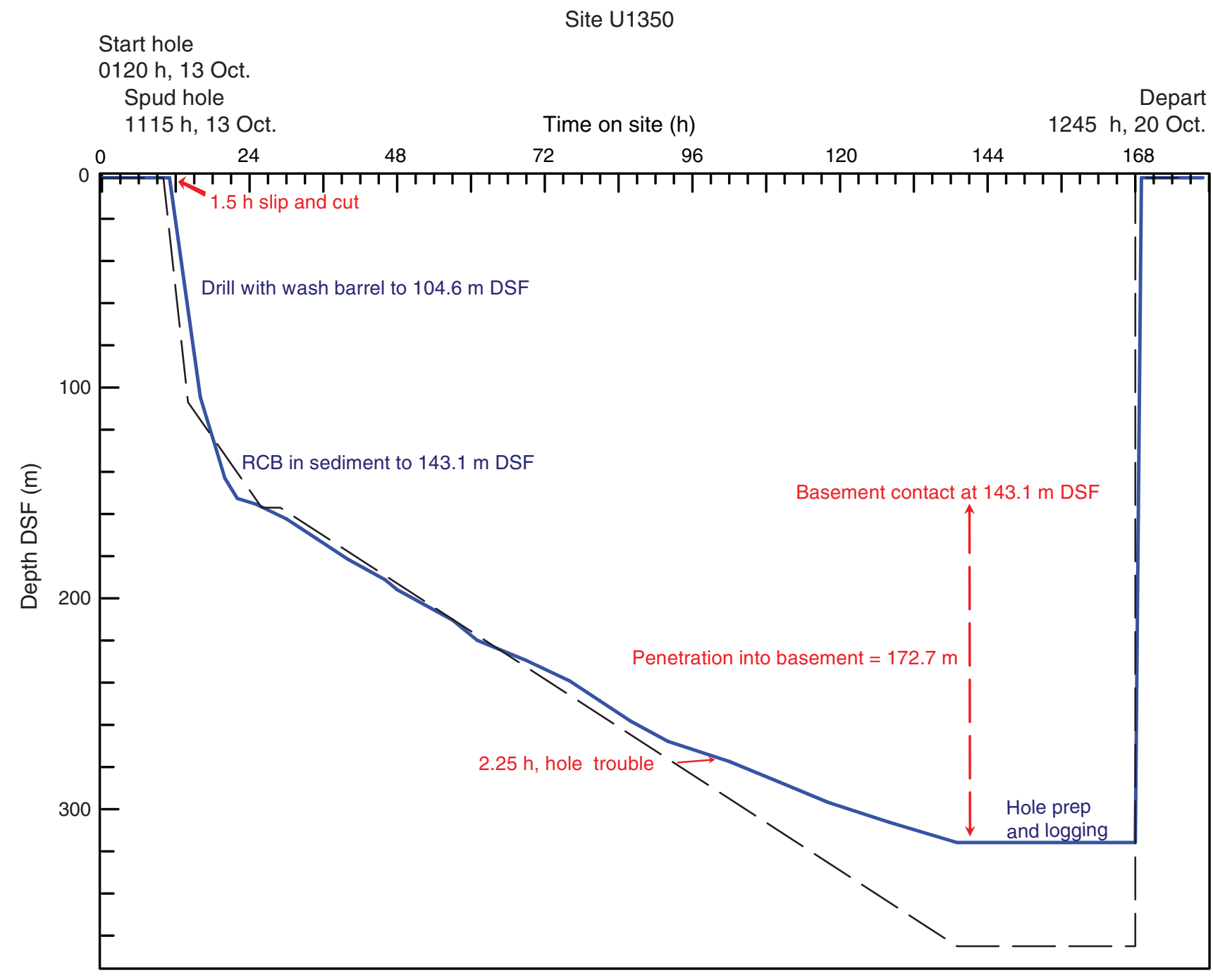


Figure F4. Lithostratigraphy, Site U1350. See "Igneous petrology" for igneous unit composition and structure.

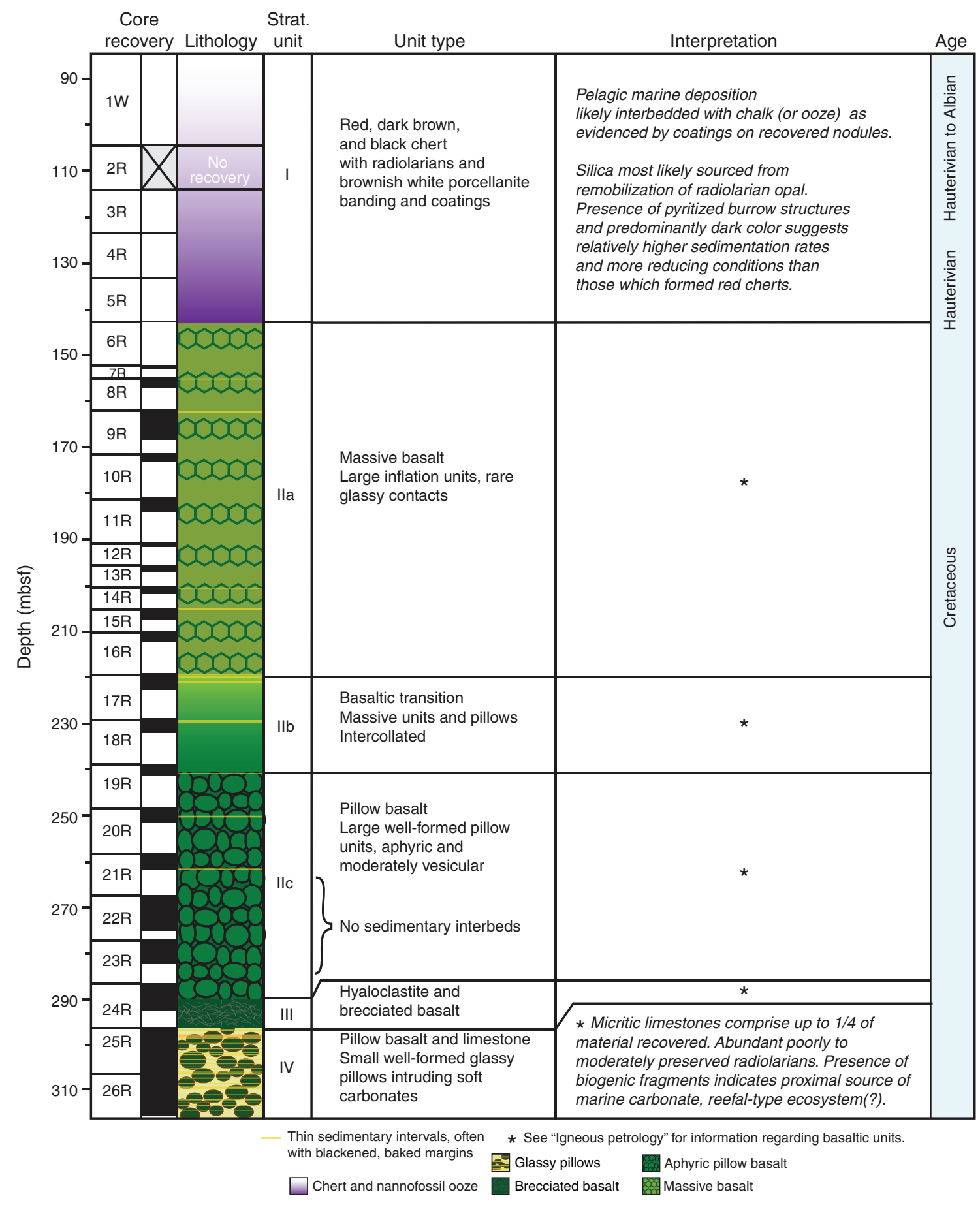


Figure F5. Photomicrographs of sedimentary features in chert in stratigraphic Unit I, Hole U1350A. A. Large, dark, infilled burrow structure cutting across relict bedding in red chert piece. B. Relict bedding highlighted by porcellanite and radiolarians $\mathrm{C}$. White porcellanite-infilled burrow structures within black chert. D. Thin burrow that has been completely replaced by pyrite within a black chert fragment. E. Pale porcellanite-infilled burrow cross section within black chert. Note halo of well-preserved radiolarians surrounding the burrow. F. Well-preserved radiolarians within glasslike silica of black chert piece.
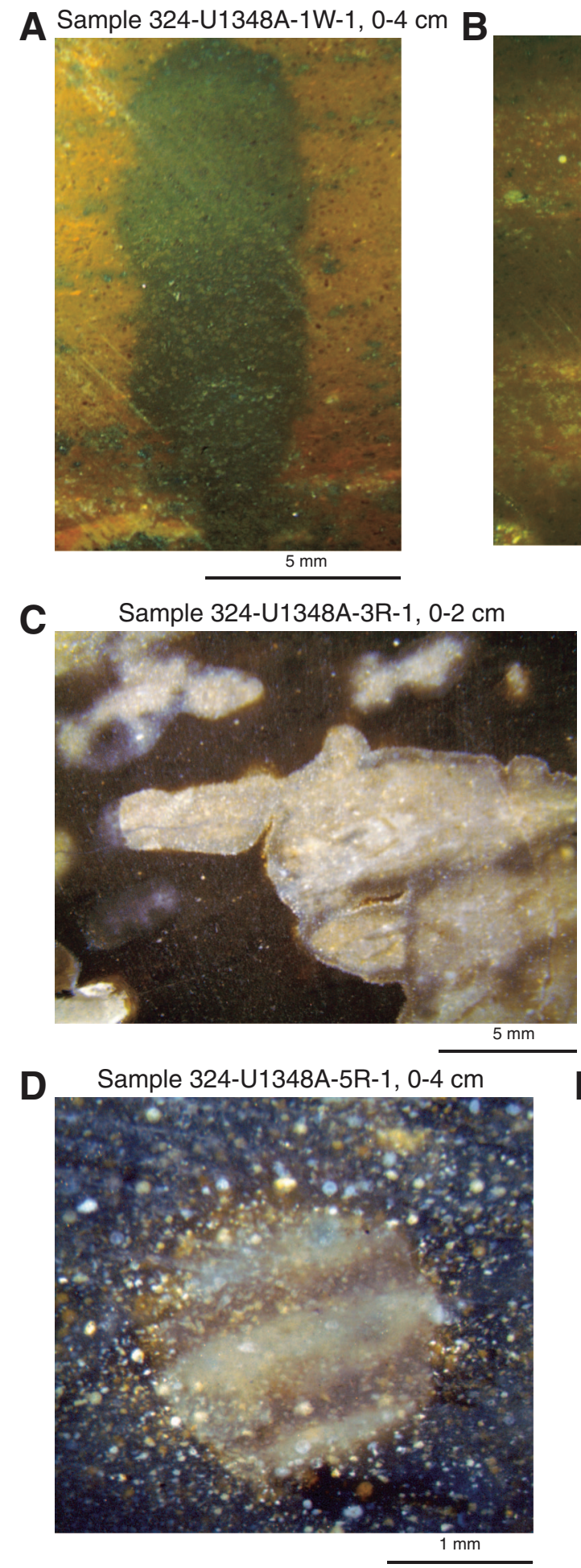

Sample 324-U1348A-1W-1, 0-4 cm
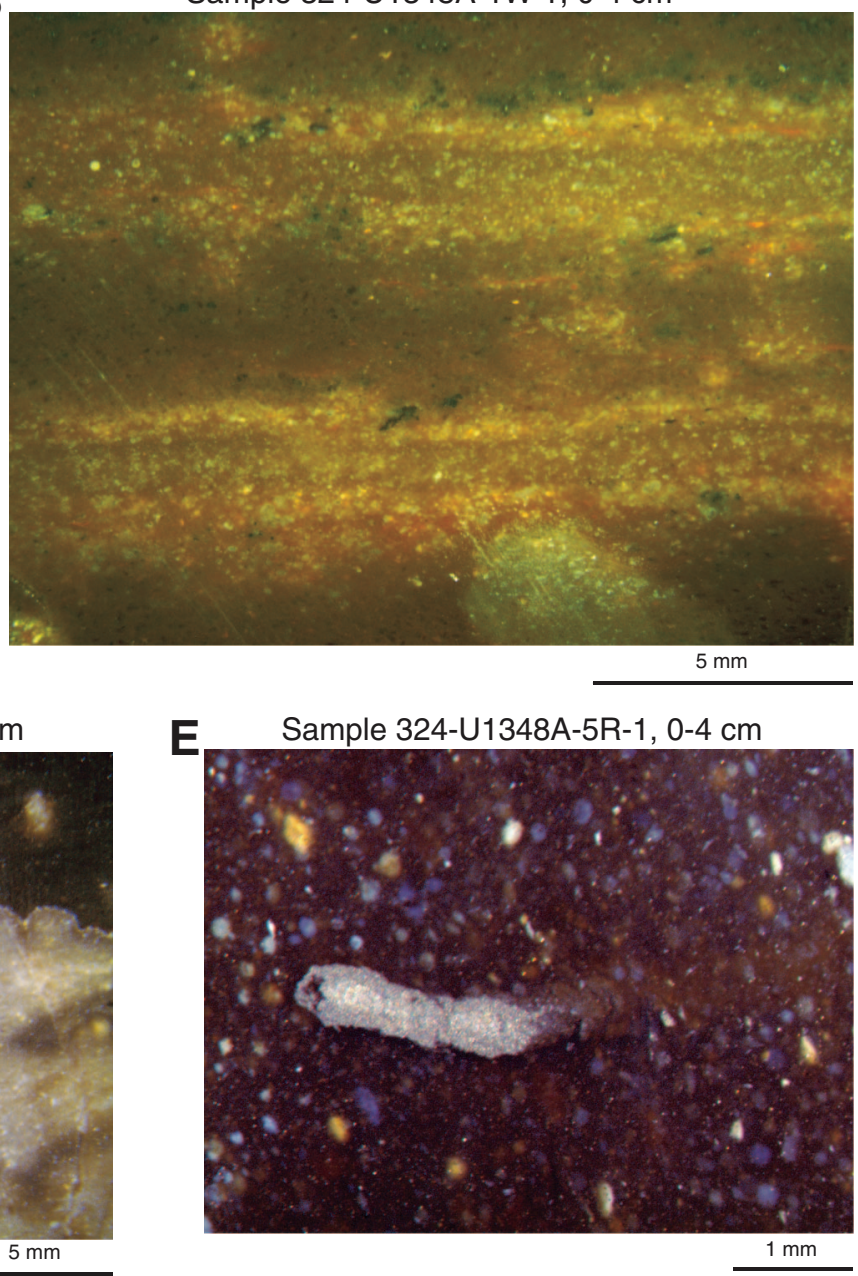

F

Sample 324-U1348A-5R-1, 0-4 cm

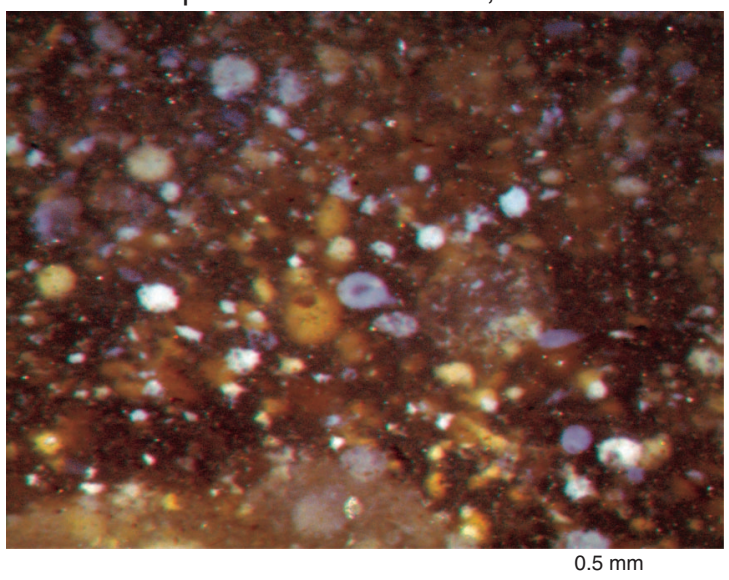


Figure F6. Photograph of limestone under binocular microscope (2.5× magnification), with secondary zeolitic alteration (blue mineral, bottom left) and pyrite (top), Hole U1350A. Orientation of the rock is not possible because of its size.

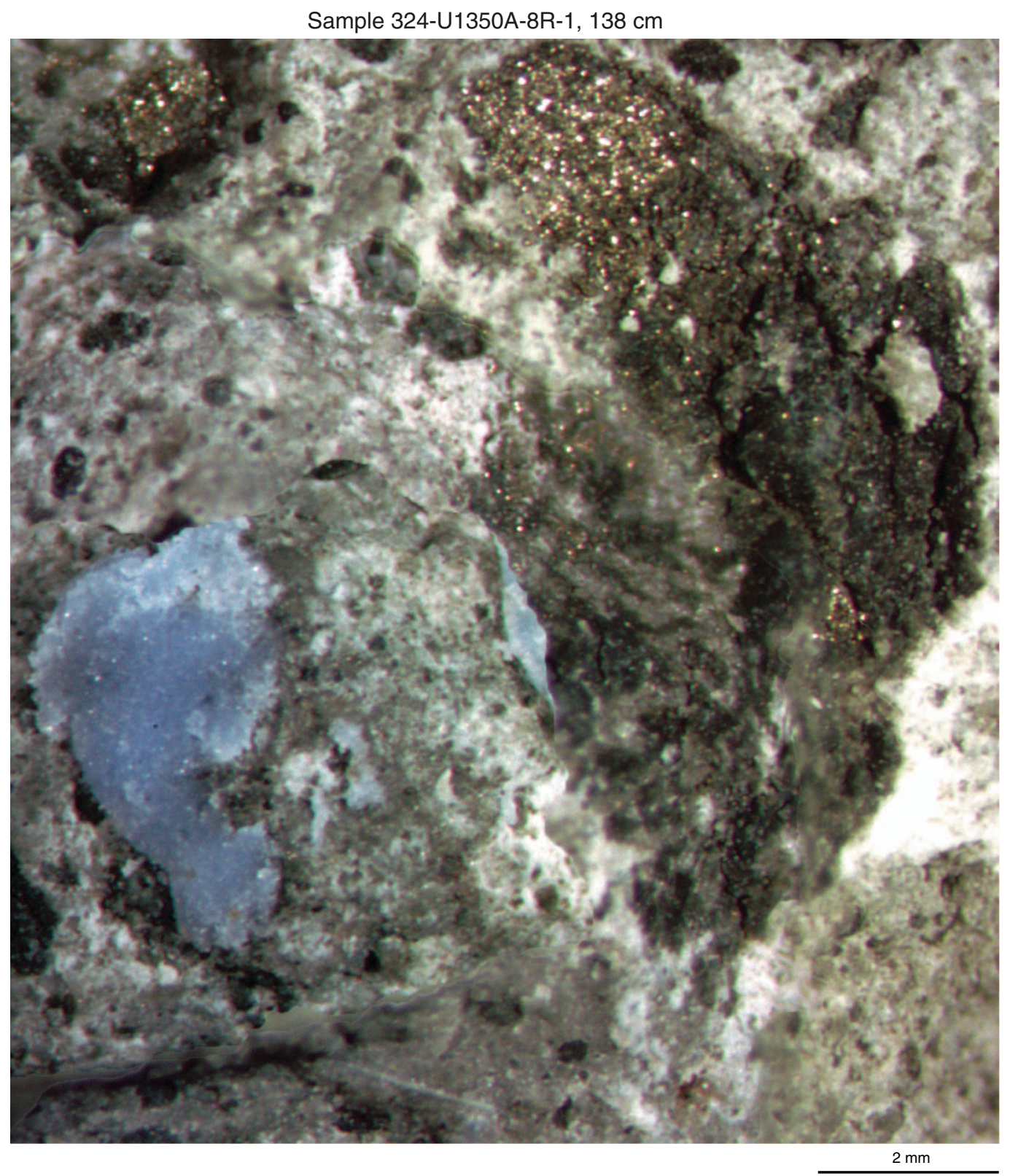


Figure F7. Photograph of sedimentary rock composed of two different lithologies, Hole U1350A. Lithologies are distinguished by a sharp color boundary and minor textural change. Coarser dark gray bed is volcaniclastic limestone, and finer, lighter colored bed above is volcaniclastic silty sandstone. Orientation of the rock is not possible because of its size.

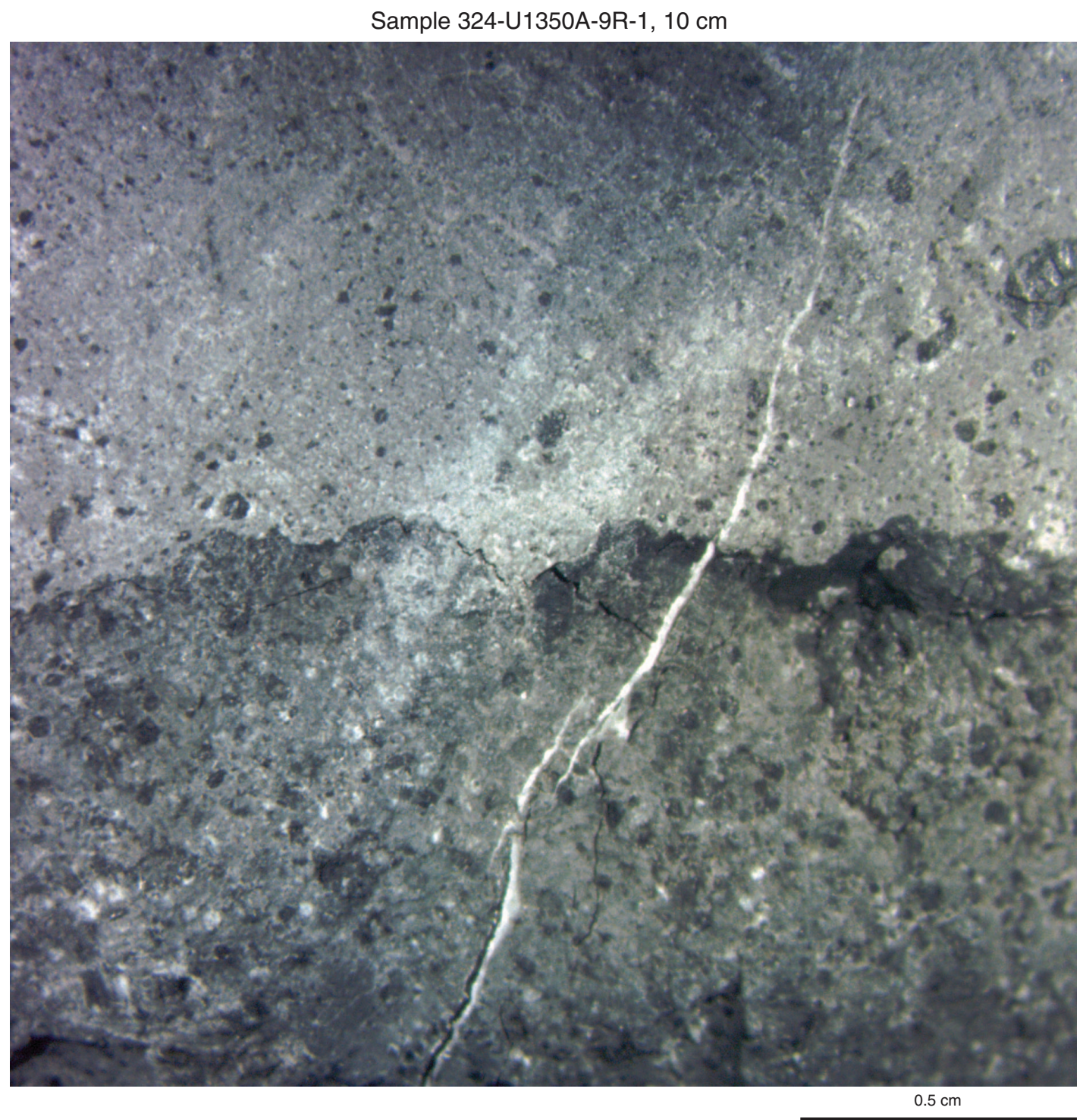


Figure F8. Thin section photomicrograph of calcite-replaced radiolarians, Hole U1350A. Several radiolarians exhibit moderate preservation and preserved structures. White round circles are poorly preserved radiolarian "ghosts." Plane-polarized light.

Interval 324-U1350A-20R-2, 43-49 cm

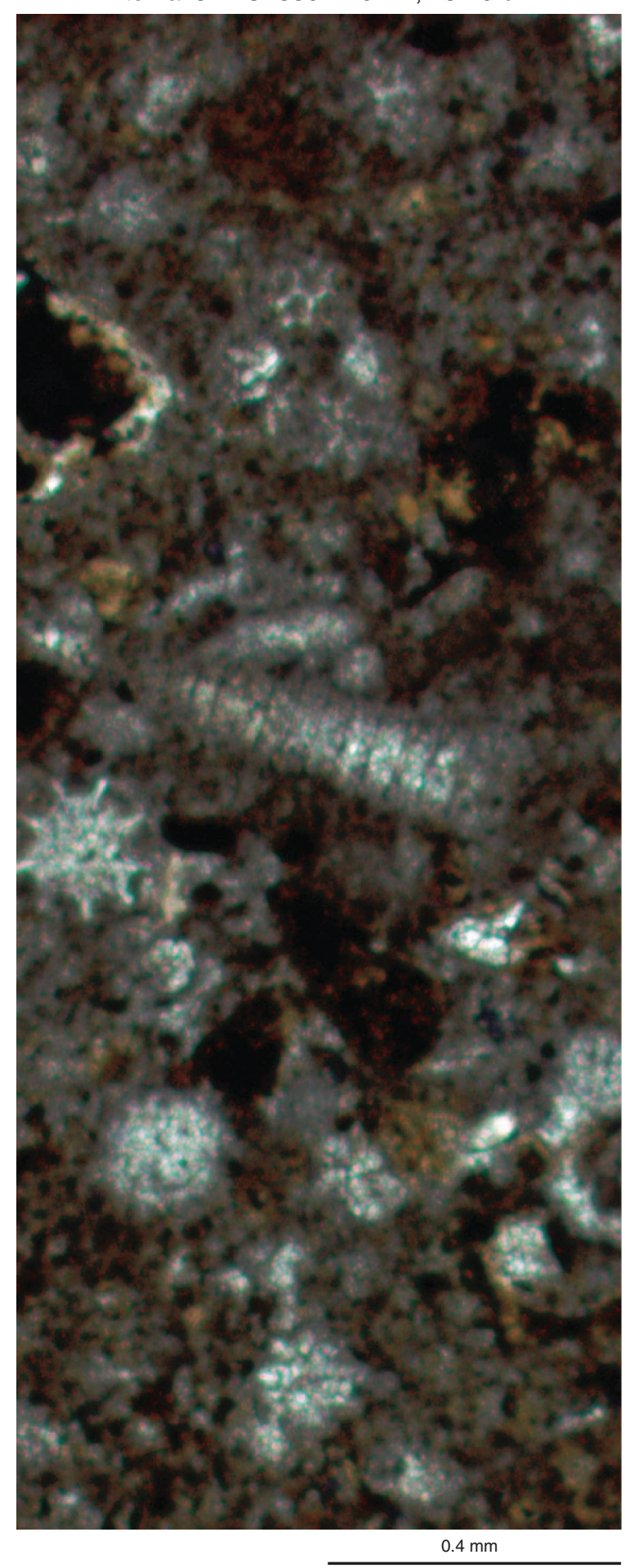


Figure F9. Thin section photomicrograph of difference in porosity and calcite cementation between (A) "fine" and (B) "coarse" hyaloclastic material in volcaniclastic sandstone, Hole U1350A. Plane-polarized light.

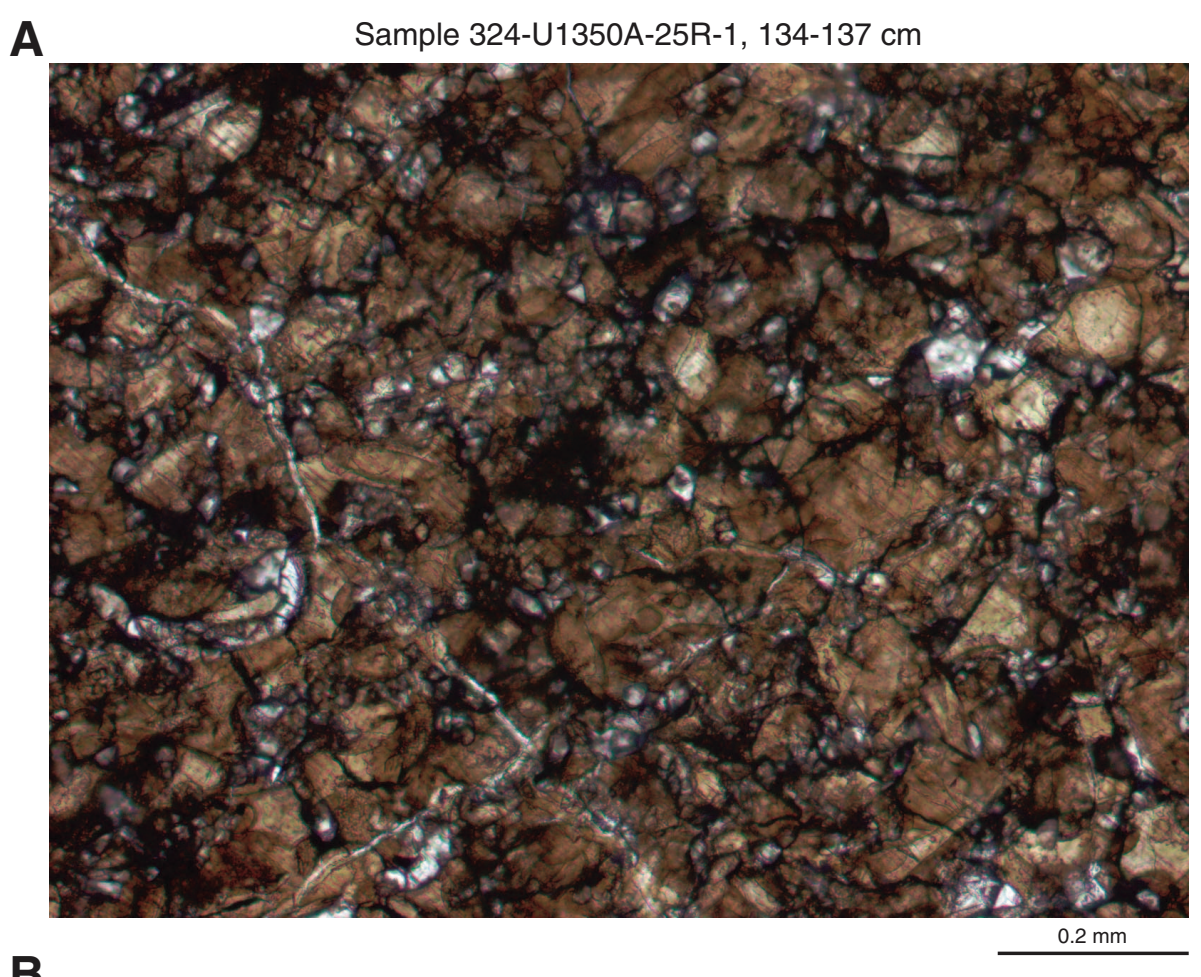

B

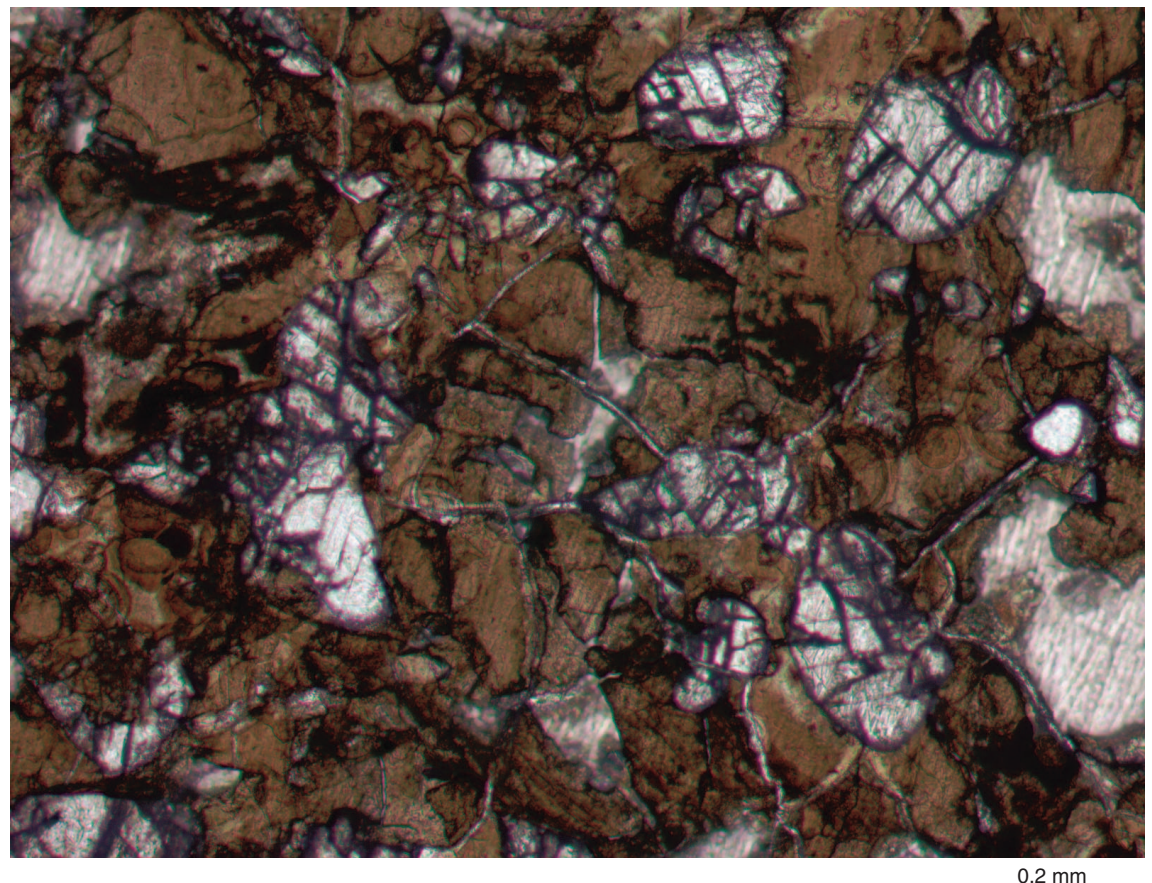


Figure F10. Core photograph of bedded volcanic sandstone, Hole U1350A. Rock is composed almost entirely of hyaloclasts and has en echelon faulting.

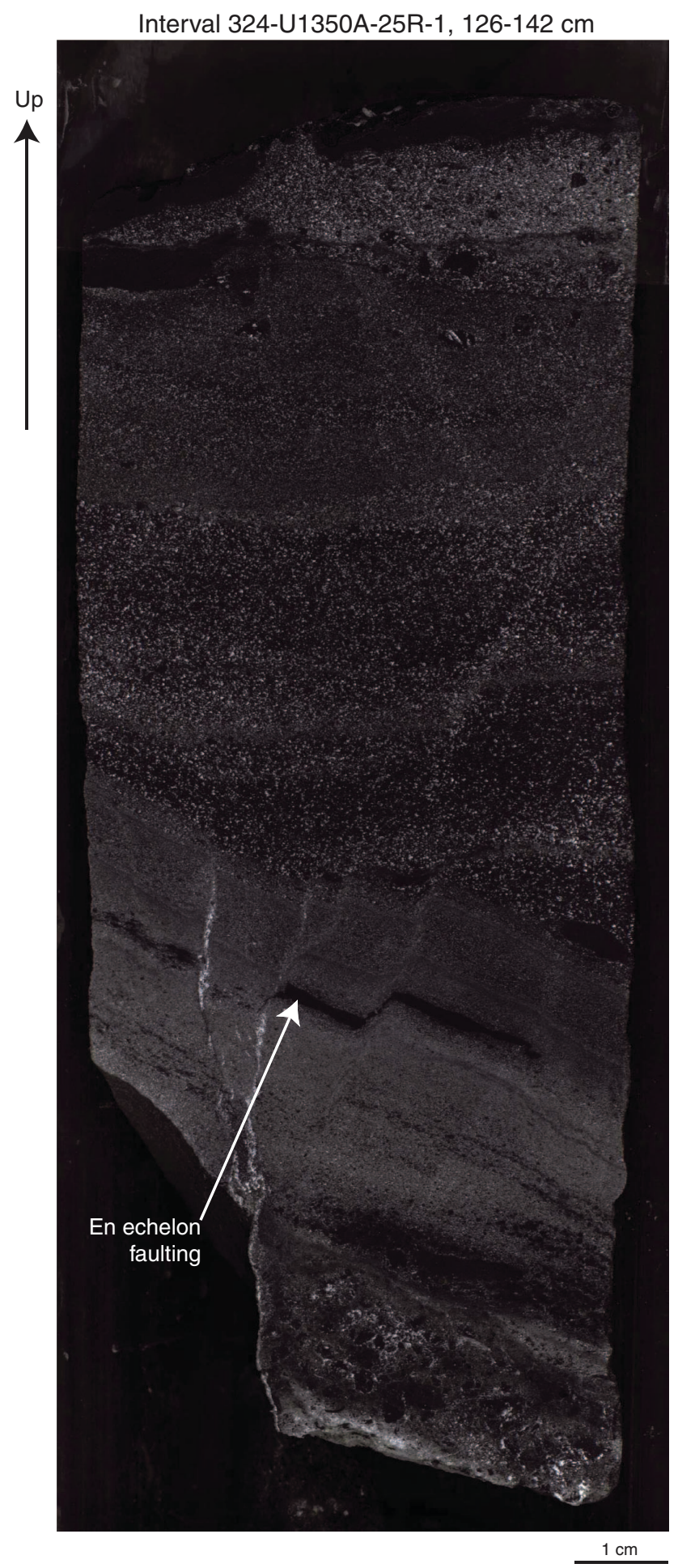


Figure F11. Thin section photomicrographs of limestone in stratigraphic Unit IV, Hole U1350A. A. Close-up of moderately preserved calcite-replaced radiolarian. Cross-polarized light. B. Biogenic and volcaniclastic components of typical micritic limestone. Plane-polarized light.
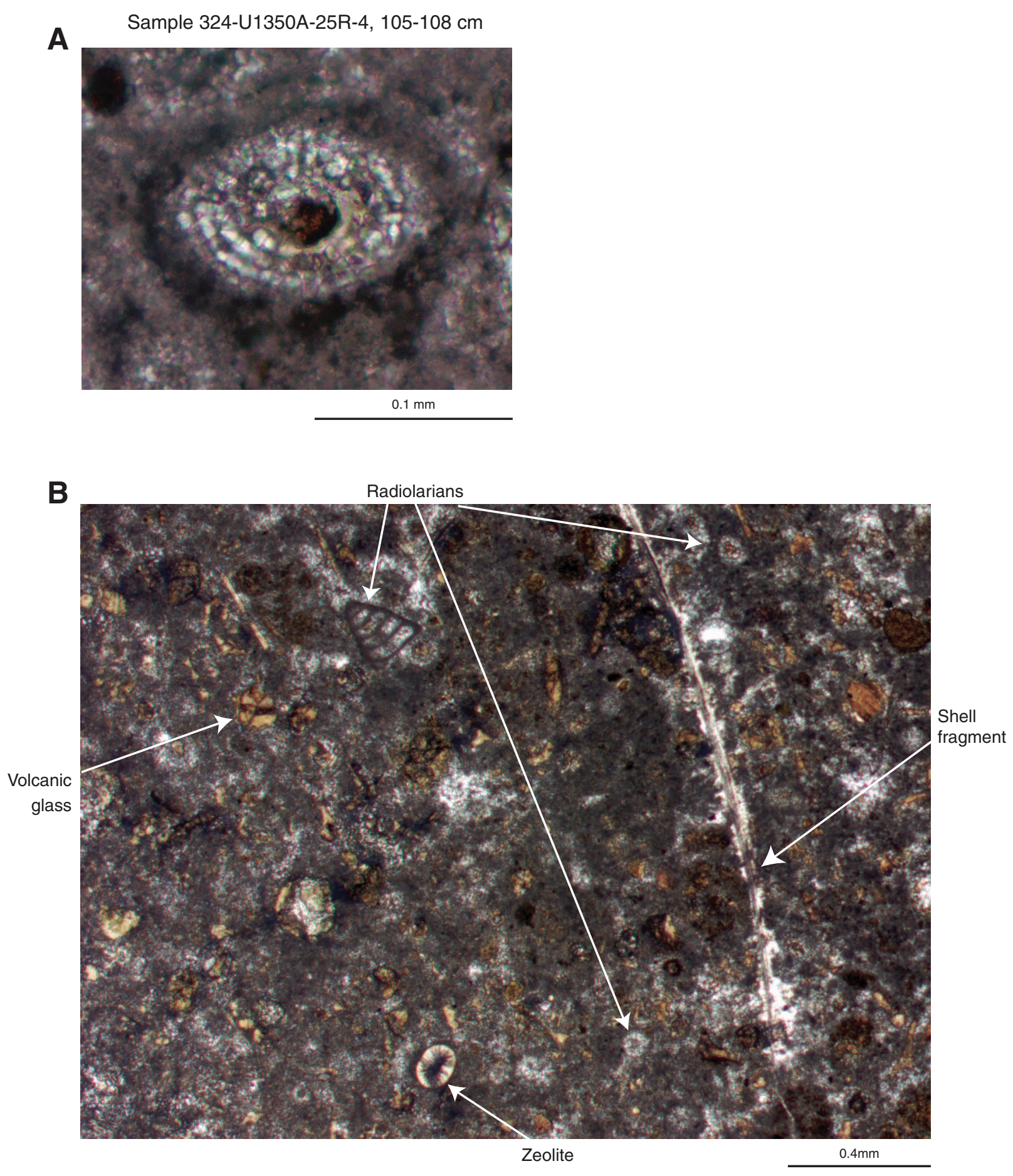
Figure F12. Recovery overview, Hole U1350A. Inflation unit thicknesses are minimal estimates based on the measured upper and lower contacts identified in the core (see Table T3 for data). Because of the lack of downhole geophysical data where core recovery is low, the lithologic log is more interpretive than in previous holes. Also shown is the recovered thickness of interbedded/intercalated sediments in the basement basalts.

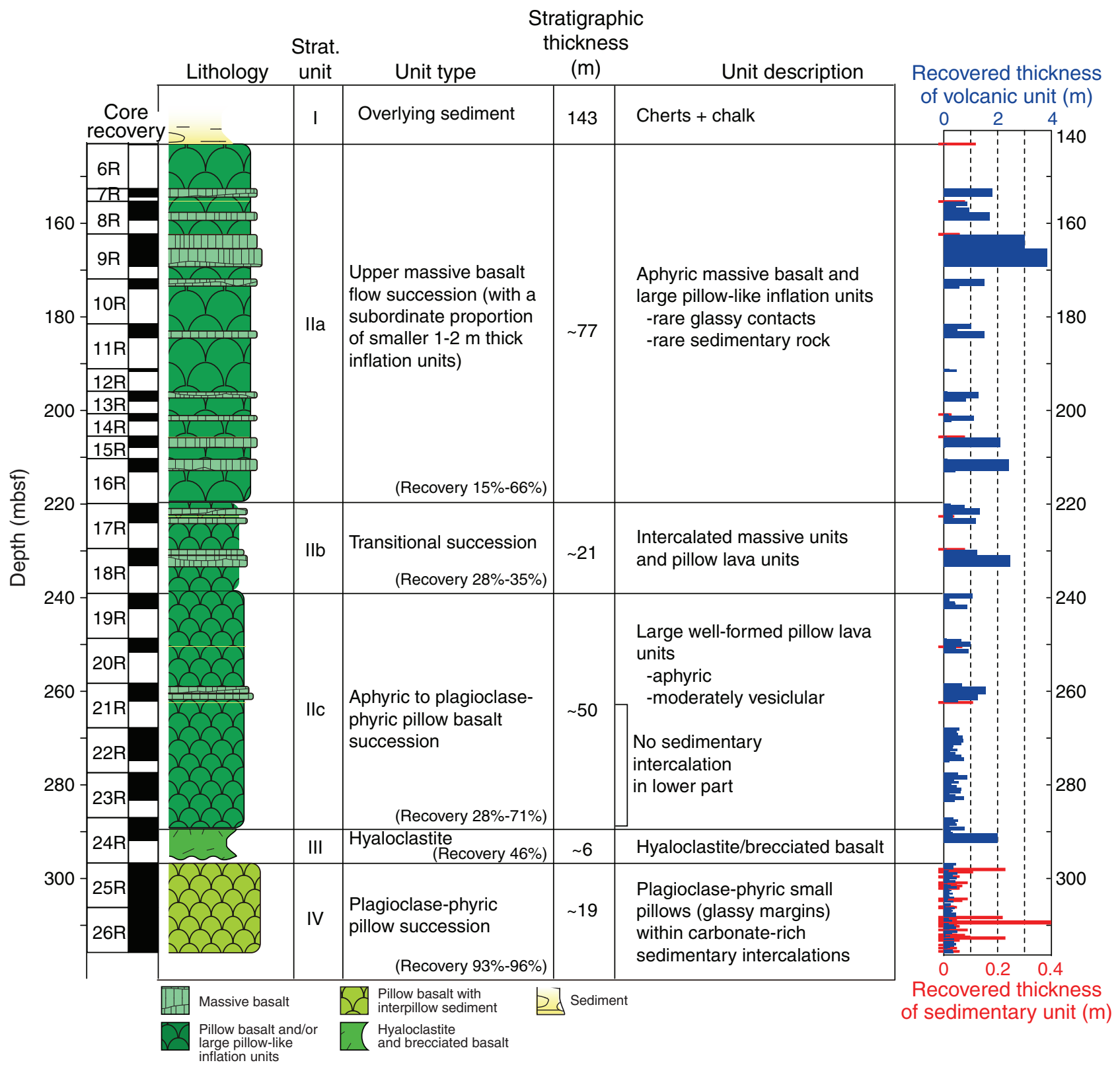


Figure F13. Overview of volcanological and physical parameters for Cores 324-U1350A-6R through 26R, Hole U1350A. NGR = natural gamma radiation, GRA = gamma ray attenuation density, MS = whole-round and pointsource magnetic susceptibility (see "Physical properties" for details).

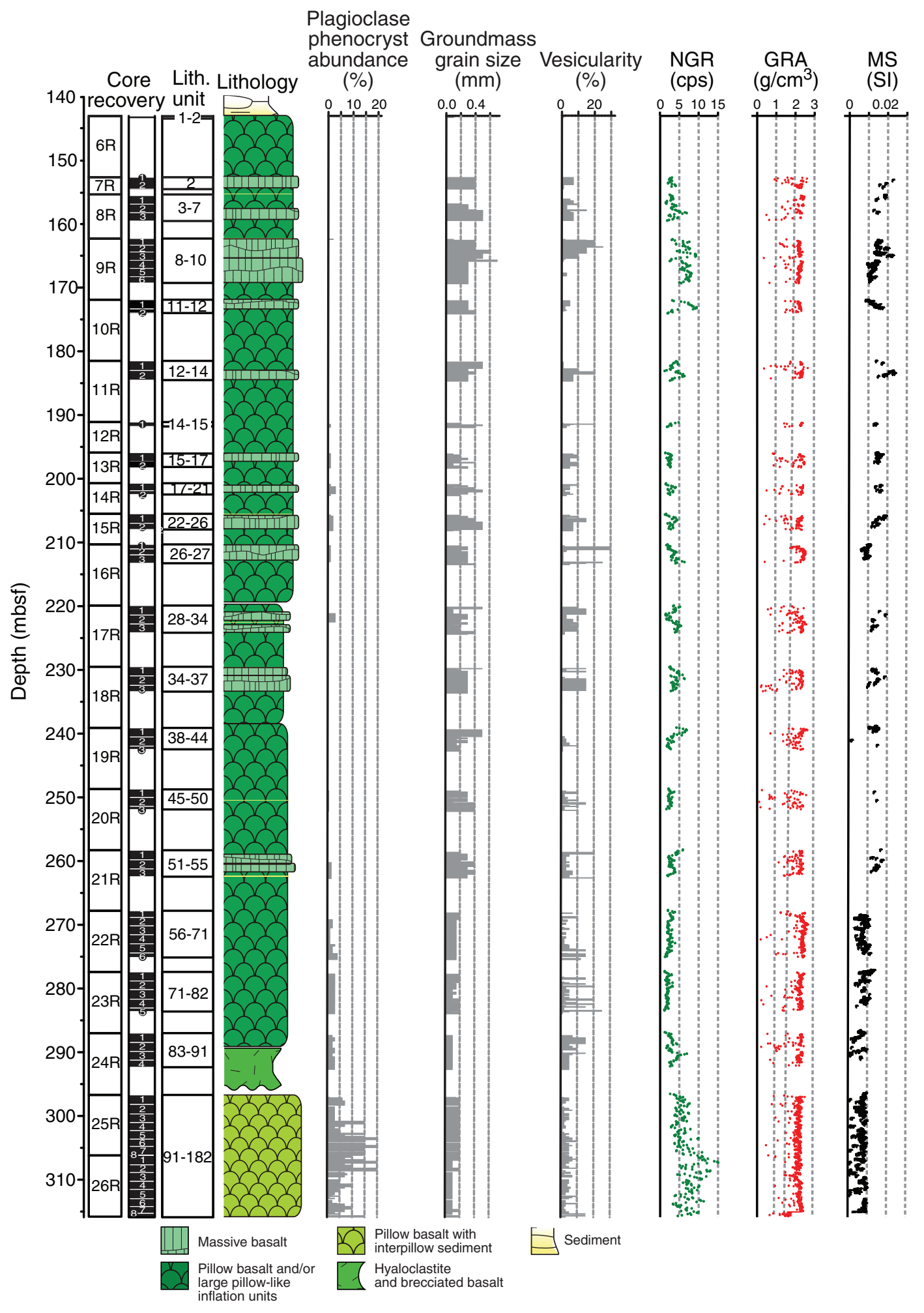


Figure F14. Examples of massive flows, Hole U1350A. A. Lithologic column. Red dashed lines $=$ upper and lower bounds of sections. B. Core images of Sections 324-U1350A-9R-6, 10R-1, 10R-2, and 11R-2. C-E. Photomicrographs of areas indicated by yellow boxes in B. C, D. Thin Section 274 (Sample 324-U1350A-10R-2, 33$35 \mathrm{~cm}$ ). Height of view of C is $12 \mathrm{~mm}$; height of view of D is $6 \mathrm{~mm}$. E. Thin Section 277 (Sample 324-U1350A11R-2, 80-83 cm). Height of view is $6 \mathrm{~mm}$. Plane-polarized transmitted light.

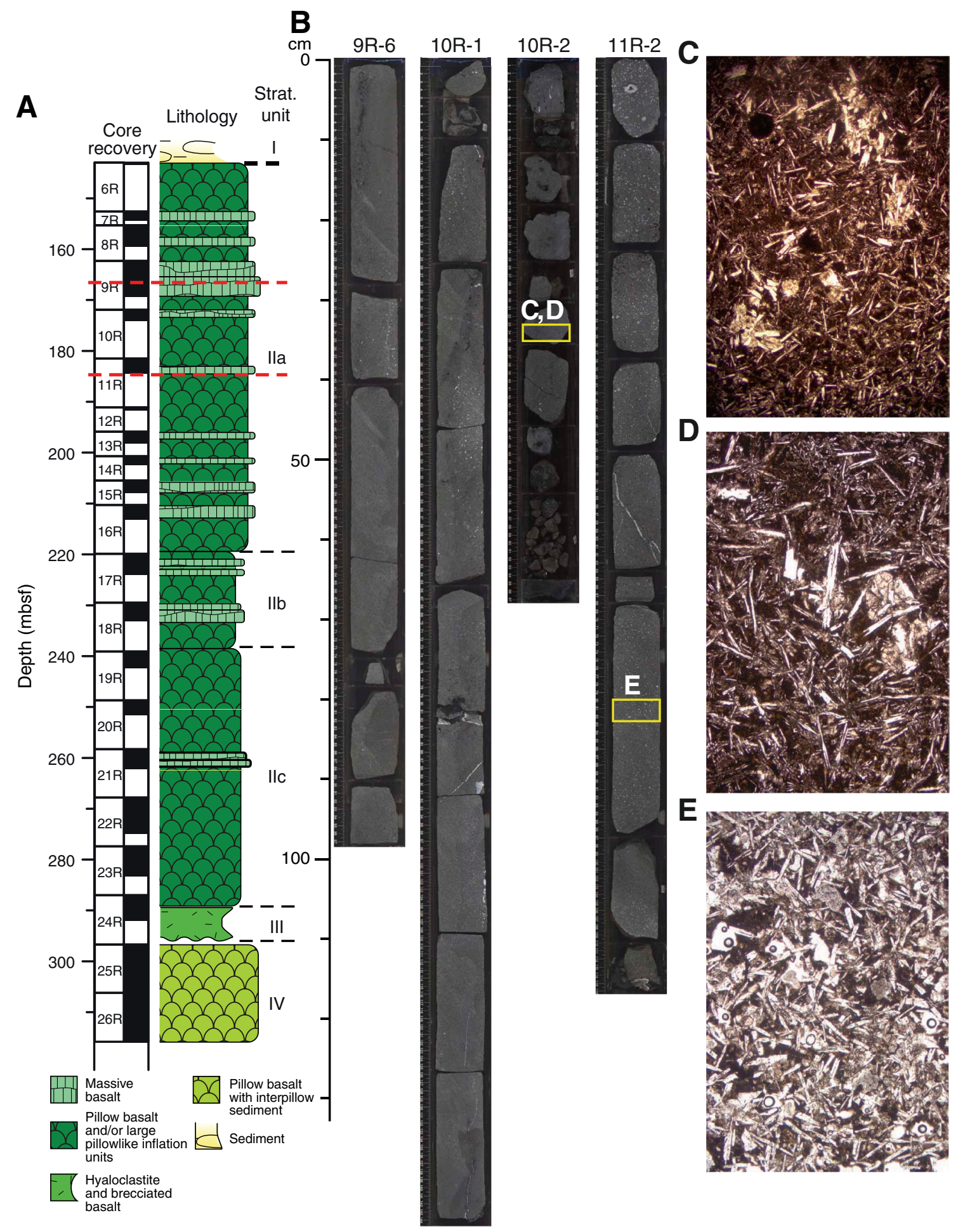


Figure F15. Examples of pillow lavas, Hole U1350A. A. Lithologic column. Red dashed lines = upper and lower bounds of sections. B. Core images of Sections 324-U1350A-22R-2 through 22R-5. Yellow boxes = locations of close up of $\mathrm{C}$ thin section. C, D. Thin section photomicrographs of aphyric pillow basalt in Subunit IIc (Thin section 307; Sample 324-U1350A-22R-5, 81-87 cm) with small spherical vesicles in the upper parts of pillows, characteristic jointing patterns, tube- and drop-shape vesicles and plagioclase glomerocrysts. E. Thin section photomicrograph of aphyric pillow basalt (Thin Section 306; Sample 324-U1350A-22R-3, 117-119 cm). Planepolarized transmitted light. Length of view of $C$ is $54.5 \mathrm{~mm}$; length of view of $\mathrm{D}$ is $9.8 \mathrm{~mm}$; length of view of $\mathrm{E}$ is $6 \mathrm{~mm}$.

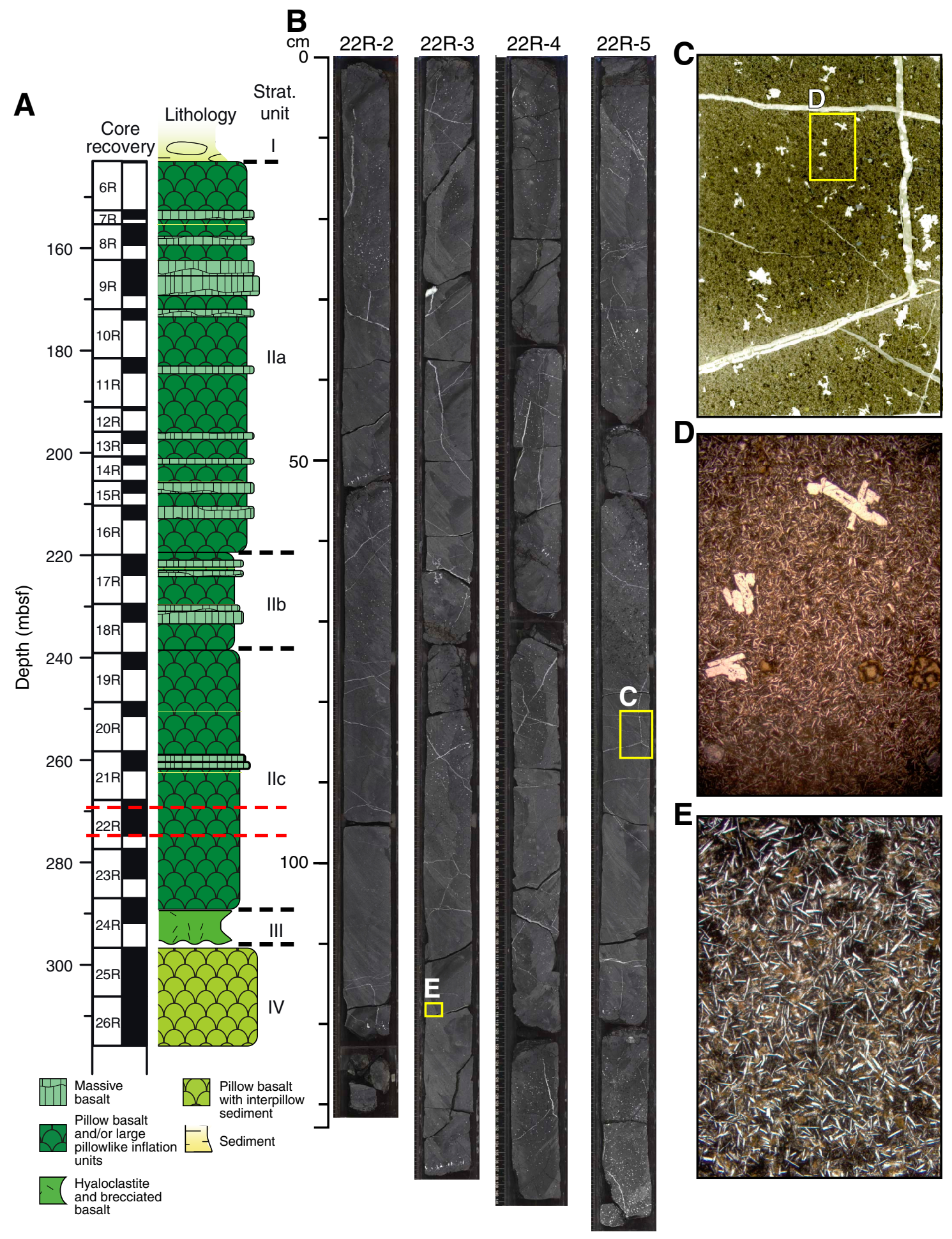


Figure F16. Examples of pillow breccia/hyaloclastite in Unit III, Hole U1350A. A. Lithologic column. Red dashed lines = upper and lower bounds of sections. B. Core image of Section 324-U1350A-24R-3 showing pillow breccia/hyaloclastite in Unit III that exhibits pillow fragments and several globular clasts with chilled margins in a matrix of hyaloclastite. Yellow boxes $=$ locations of core section images. C. Interval 324-U1350A-24R-3, 105-120 cm. D. Interval 324-U1350A-24R-3, 90-105 cm. E. Interval 324-U1350A-24R-3, 49-67 cm.

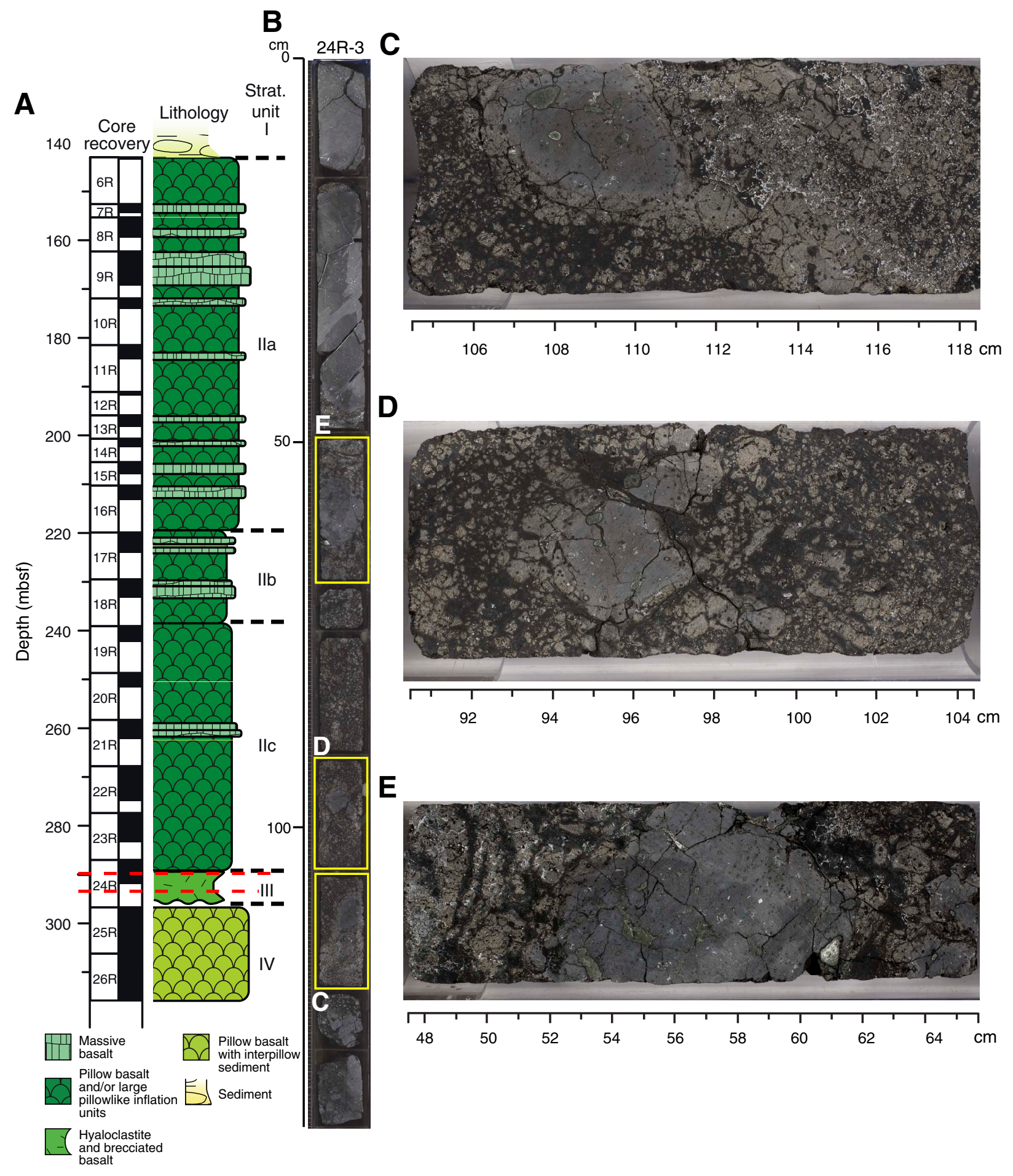


Figure F17. Core section images annotated with volcanological features for pillow basalts in Unit IV, Hole U1350A (Sections 324-U1350A-25R-1 through 25R-8). Yellow dashed lines = pillow margins or interpillow crusts. These core sections exhibit globular peperite textures where pillow basalt and unconsolidated pelagic sediment have mixed, interior pillow cracks, concentric vesicles in pillow margins, and sediment incorporated into pillow interiors.

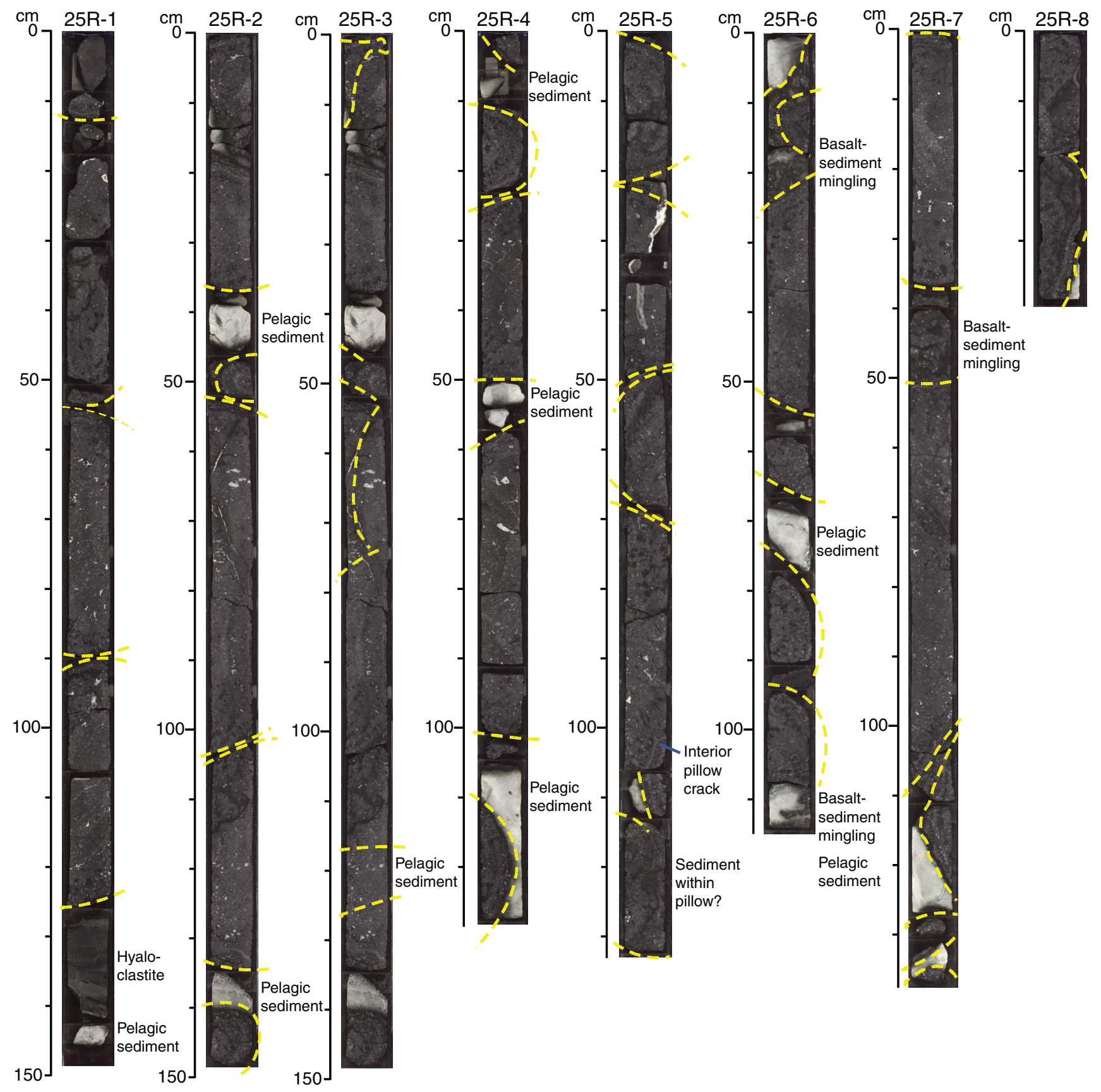


Figure F18. Core section images annotated with volcanological features for pillow basalts in Unit IV, Hole U1350A (Sections 324-U1350A-26R-1 through 26R-8). Yellow dashed lines = pillow margins or interpillow crusts. These core sections exhibit interior pillow cracks, concentric vesicles in pillow margins, and sediment incorporated into pillow interiors.

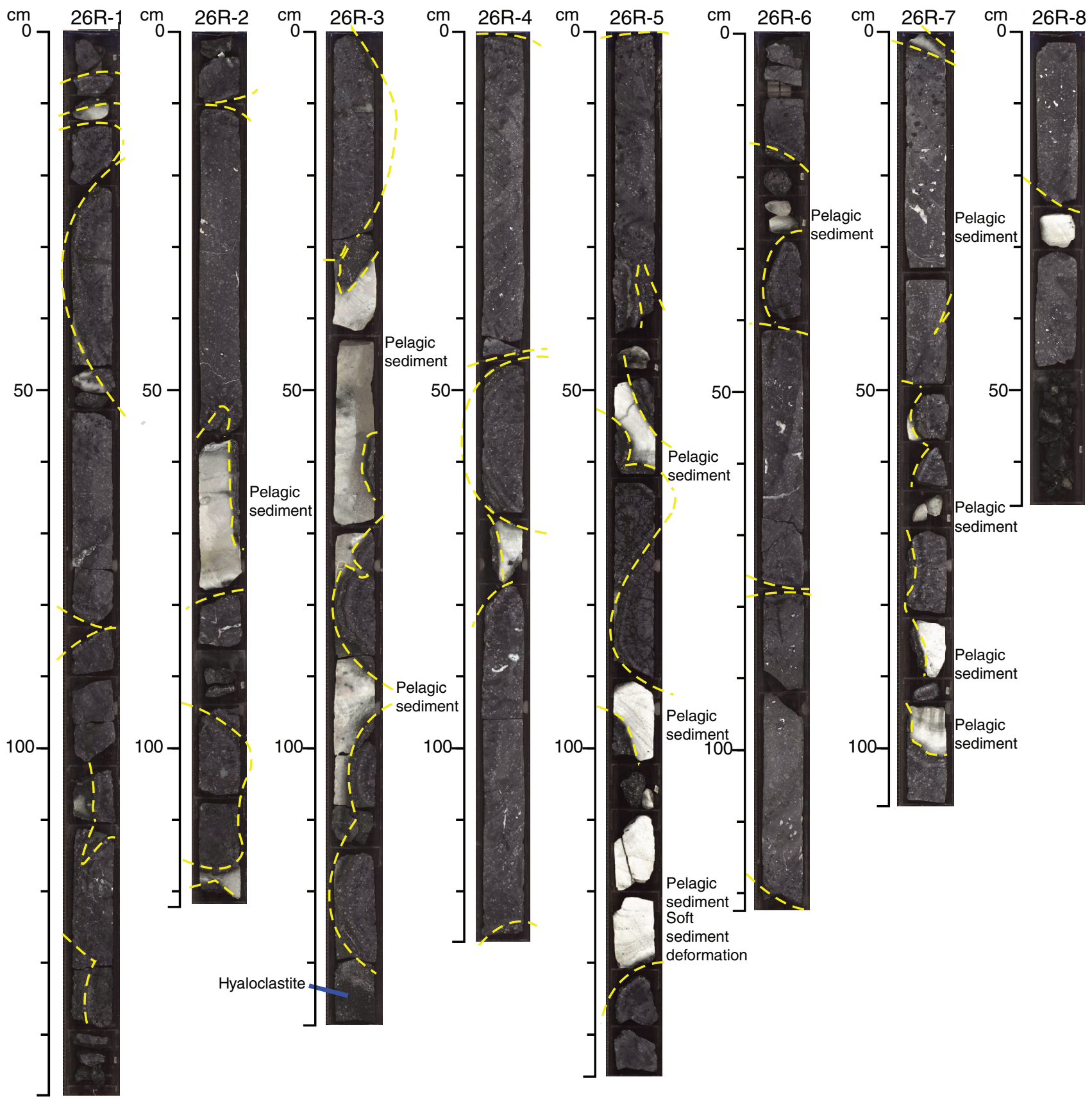


Figure F19. Core section images, Hole U1350A. Core sections exhibit well-preserved pillow margins and intercalated with fine, micritic sediment. Relatively small pillow lobes are intruded into poorly consolidated sediment that was squeezed up between pillows and filled areas in pillows that fractured during emplacement. A. Interval 324-U1350A-25R-4, 111-127 cm. B. Interval 324-U1350A-26R-3, 111-121 cm. C. Interval 324U1350A-26R-3, 70-89 cm. D. Interval 324-U1350A-25R-6, 106-113 cm. E. Interval 324- U1350A-26R-5, 61-86 $\mathrm{cm}$.

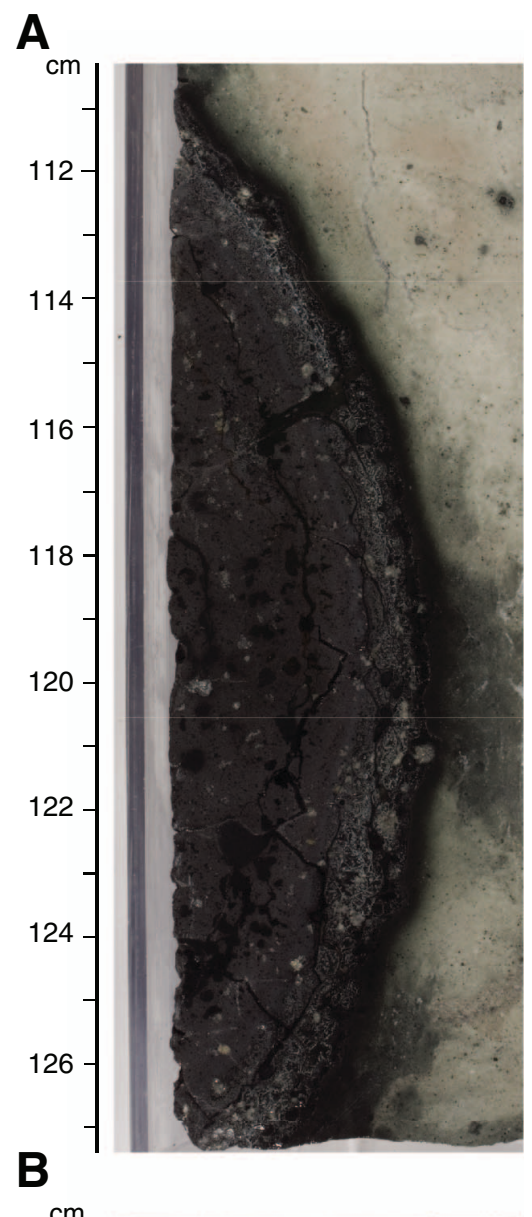

C
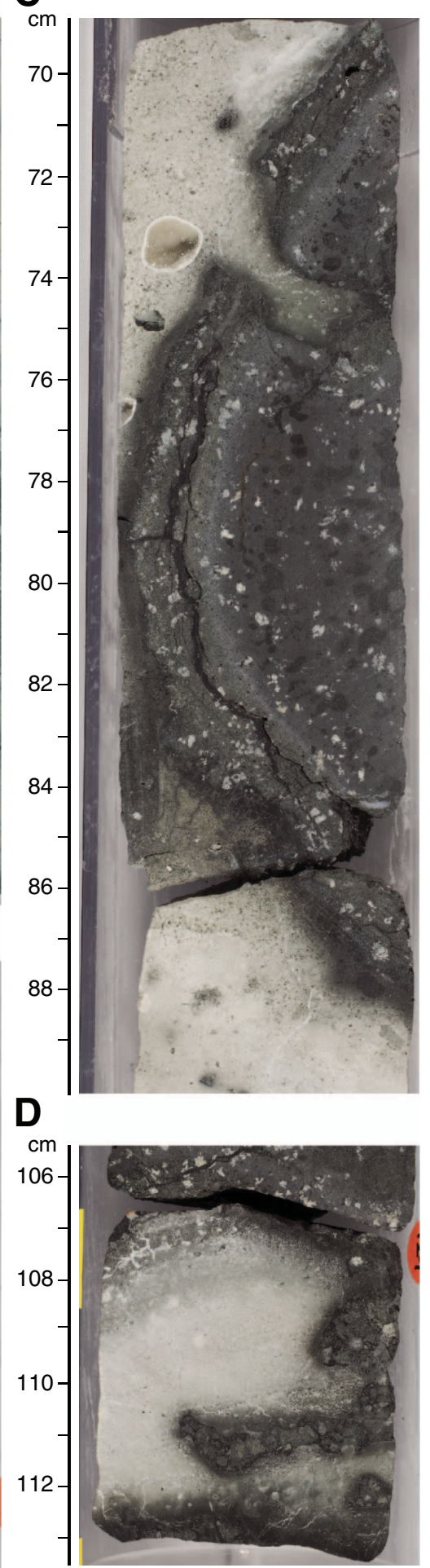

E

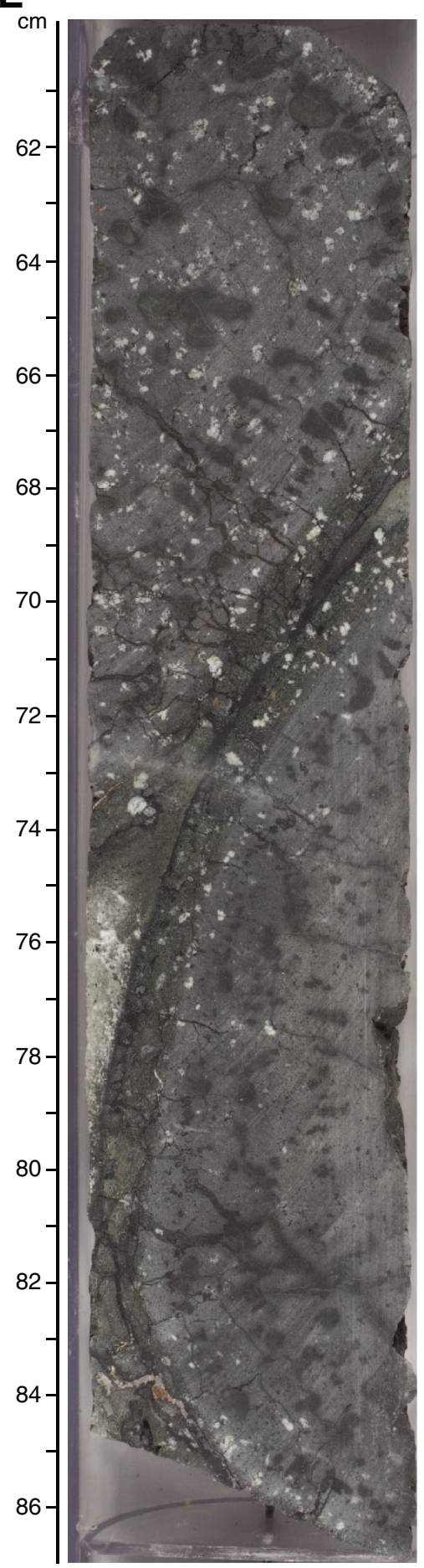


Figure F20. Depth profiles of modal abundances of olivine, clinopyroxene, and plagioclase occurring as either phenocrysts or microphenocrysts observed in thin section. Red dotted lines = recovered depths of unit boundaries. $\operatorname{Tr}=$ trace of phenocryst phases only, displayed for convenience as $-0.5 \%$.

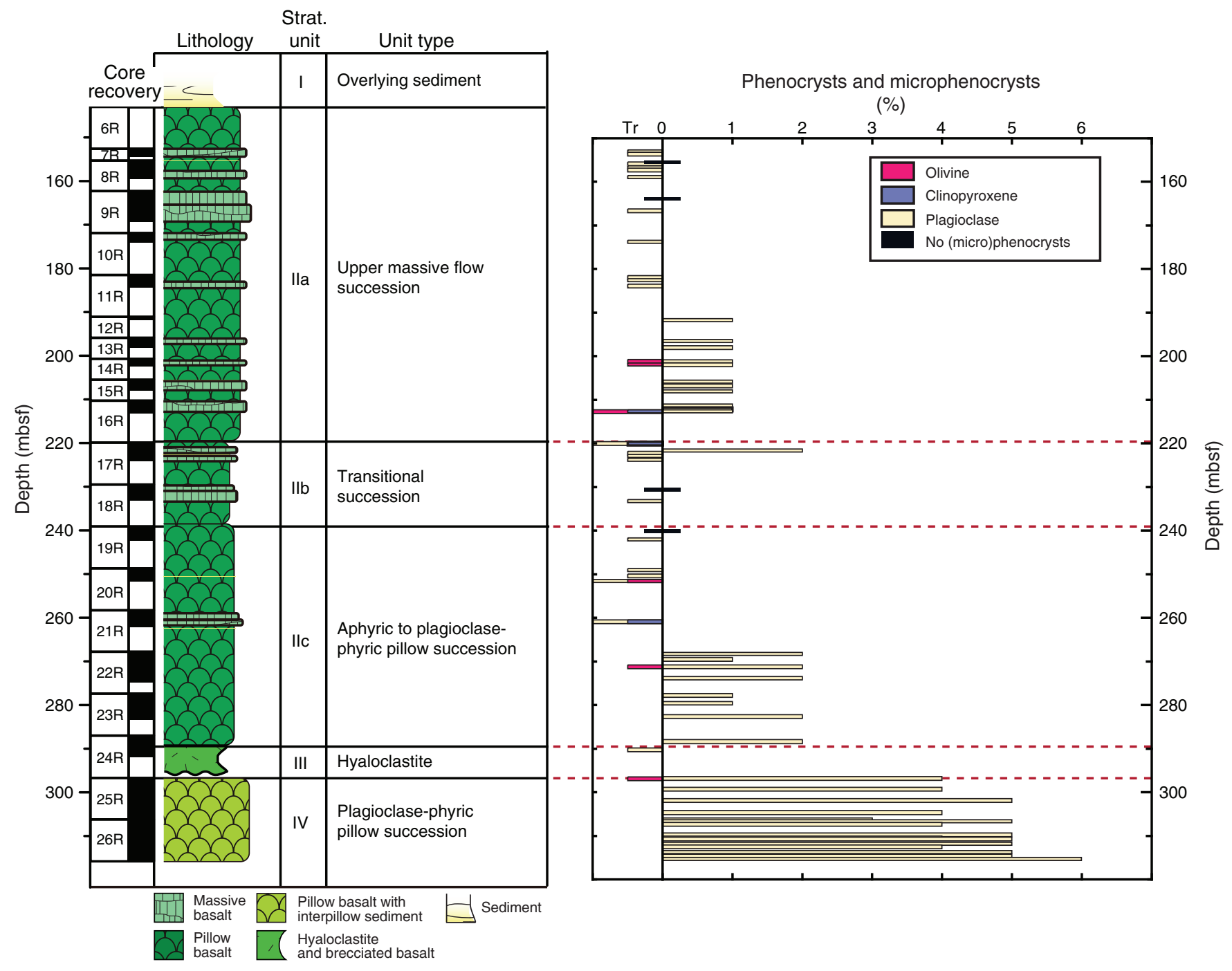


Figure F21. Photomicrographs of textures in flow interiors of basalt, Hole U1350A. A, B. Plagioclase network Type 1 (Thin Section 264; Sample 324-U1350A-7R-1, 51-53 cm). C, D. Plagioclase-clinopyroxene network Type 2 (Thin Section 296; Sample 324-U1350A-18R-3, 78-80 cm). E, F. Contrast across a boundary between a host rock and a segregation vein (Thin Section 273; Sample 324-U1350A-9R-4, 84-87 cm). A, C, and E are under plane-polarized light; B, D, and F are under reflected light.
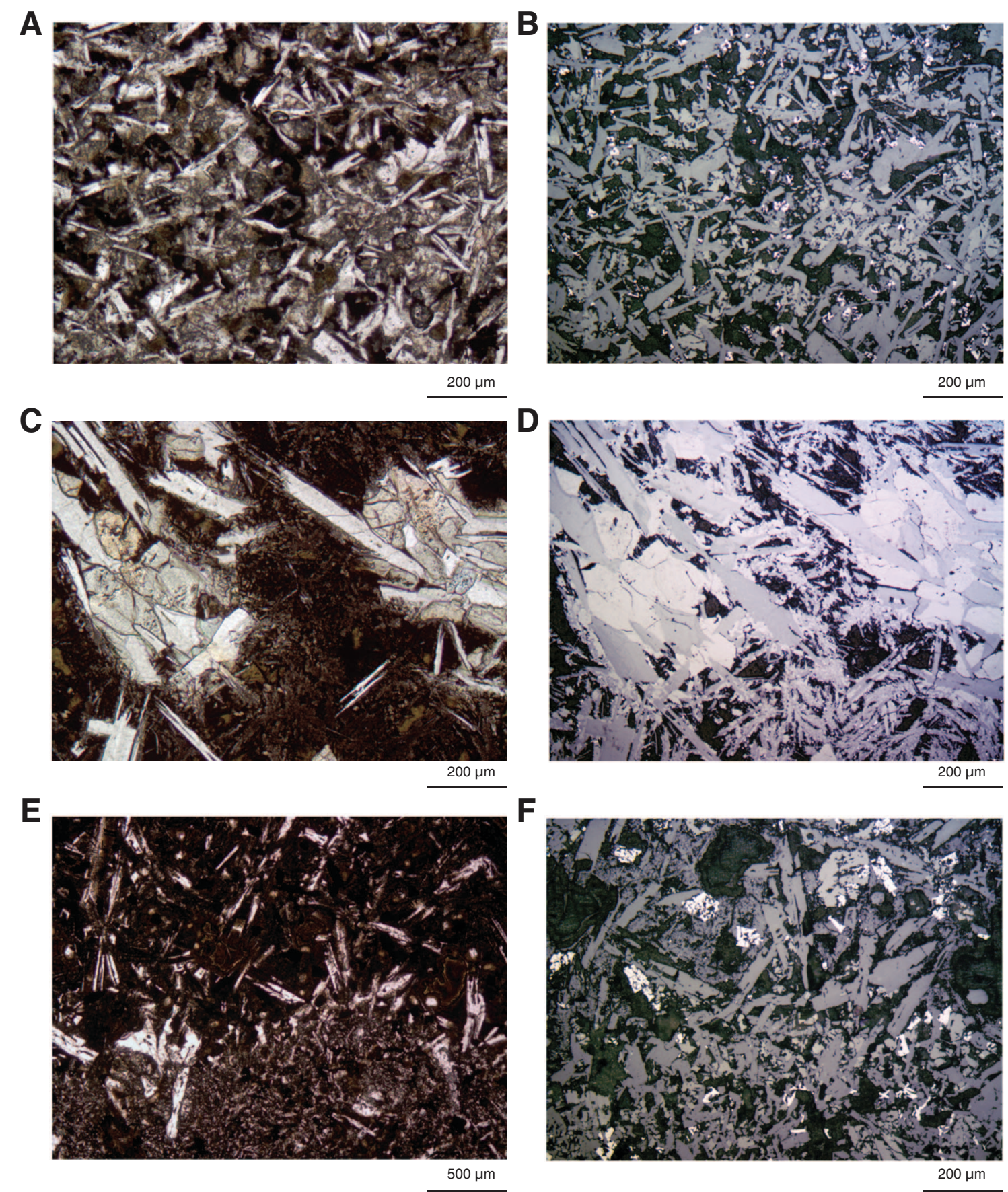
Figure F22. Photomicrographs of textures in flow interiors of basalt in order of depth, Hole U1350A. A-D, H. Textural Type 1, with plagioclase networks. E-G. Textural Type 2, with plagioclase-clinopyroxene networks. A. 153.82 mbsf (Thin Section 266; Sample 324-U1350A-7R-1, 122-123 cm). B. 166.57 mbsf (Thin Section 273; Sample 324-U1350A-9R-4, 84-87 cm). C. 182.5 mbsf (Thin Section 276; Sample 324-U1350A-11R-1, 101-105 cm). D. 202.00 mbsf (Thin Section 282; Sample 324-U1350A-14R-2, 13-15 cm). E. 212 mbsf (Thin Section 288; Sample 324-U1350A-16R-3, 35-39 cm). F. 222.76 mbsf (Thin Section 293; Sample 324-U1350A-17R-2, 137$139 \mathrm{~cm}$ ). G. 233.22 mbsf (Thin Section 296; Sample 324-U1350A-18R-3, 79-80 cm). H. 271.34 mbsf (Thin Section 306; Sample 324-U1350A-22R-3, 117-119 cm). Reflected light.

A

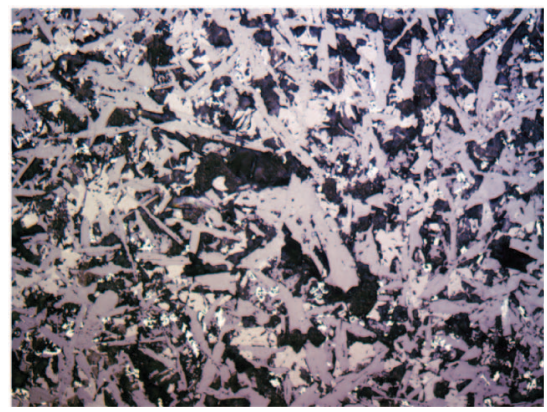

C

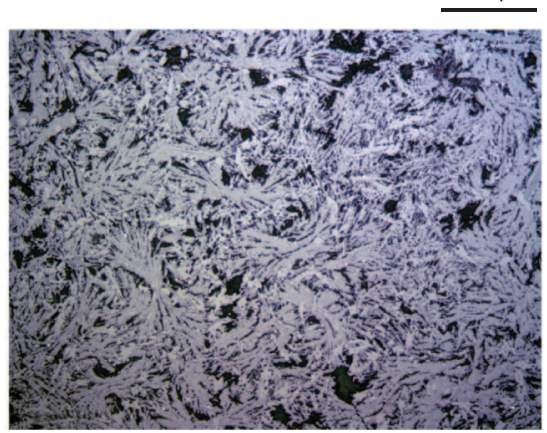

E

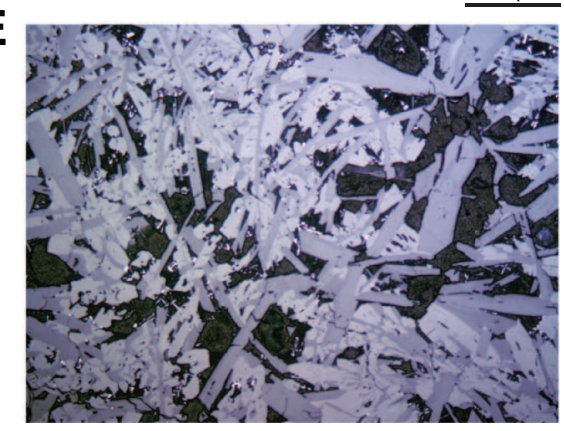

G

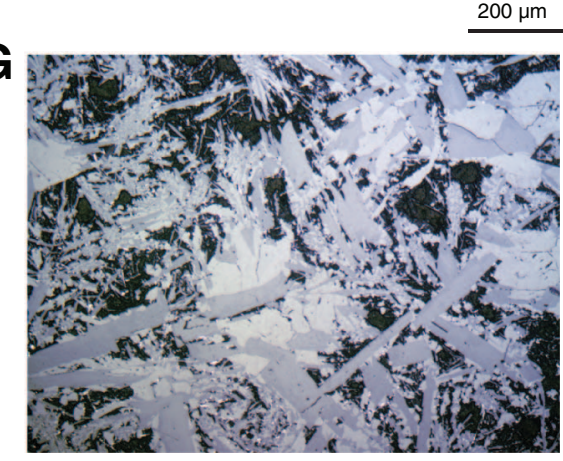

B
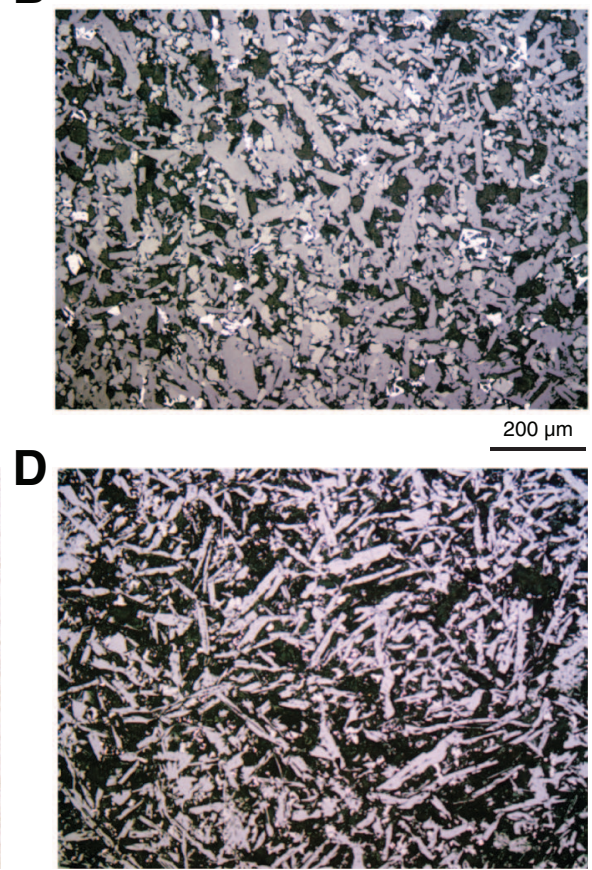

$200 \mu \mathrm{m}$

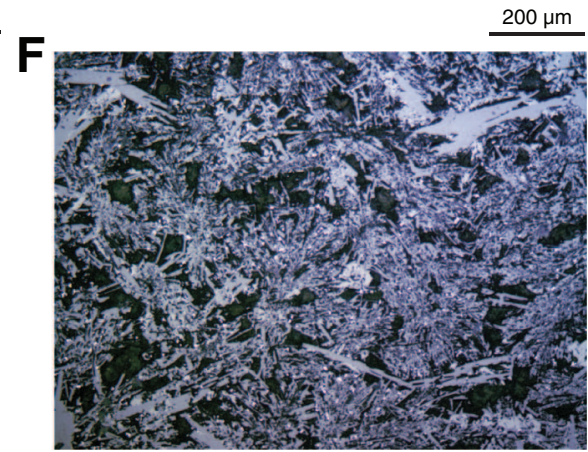

$200 \mu \mathrm{m}$

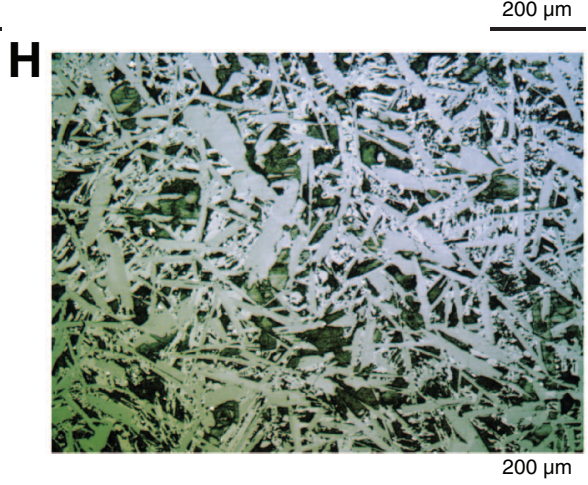


Figure F23. Photomicrographs of plagioclase and clinopyroxene phenocrysts and their intergrowths, Hole U1350A. A-D. Textural Type 1: (A) intergrowths of plagioclase and brighter clinopyroxene phenocrysts, (B) separate plagioclase (bright white) and clinopyroxene microphenocrysts in an aphyric groundmass, (C) clump of plagioclase (first order birefringence) and clinopyroxene (second order birefringence) phenocrysts in an aphyric groundmass, and (D) Monomineralic clump of plagioclase phenocrysts. (Thin Section 276; Sample 324-U1350A-11R-1, 101-105 cm). E, F. Textural Type 2: intergrowths of plagioclase and pyroxene (Thin Section 293; Sample 324-U1350A-17R-2, 137-139 cm). A and F are under reflected light; B and E are under plane-polarized light; $\mathrm{C}$ and $\mathrm{D}$ are under cross-polarized light.
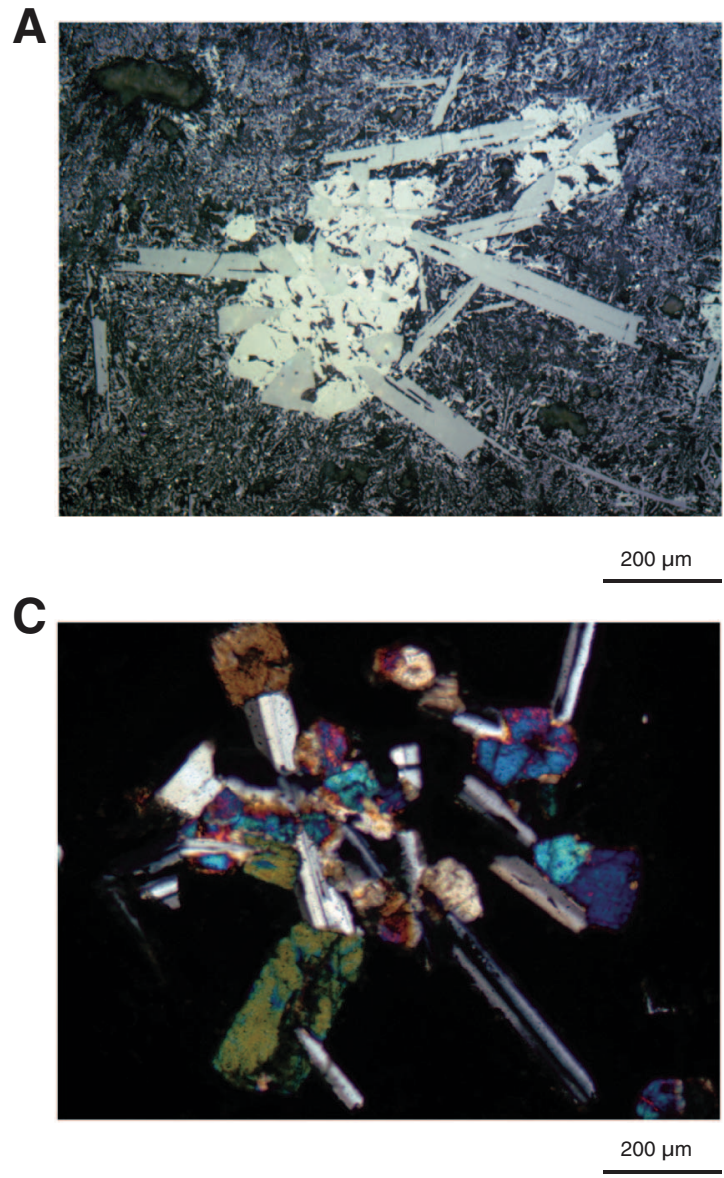

E

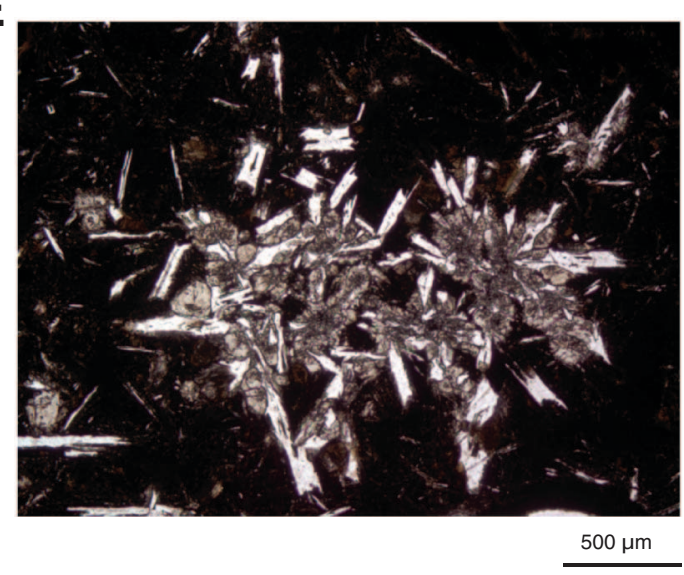

B

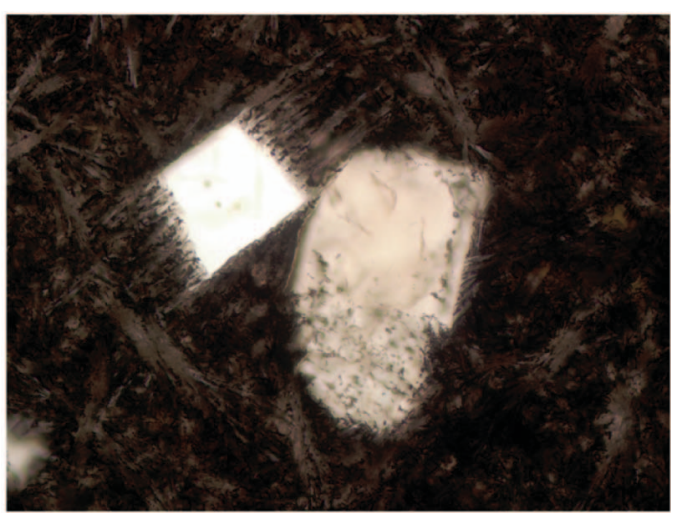

$100 \mu \mathrm{m}$

D

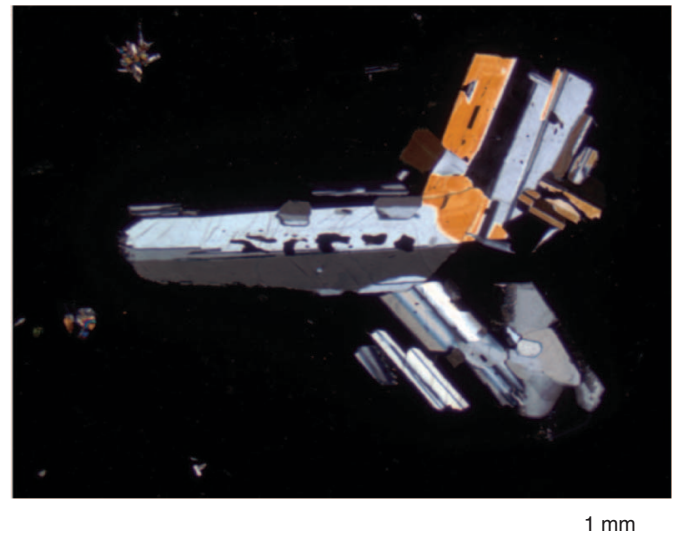

$\mathbf{F}$

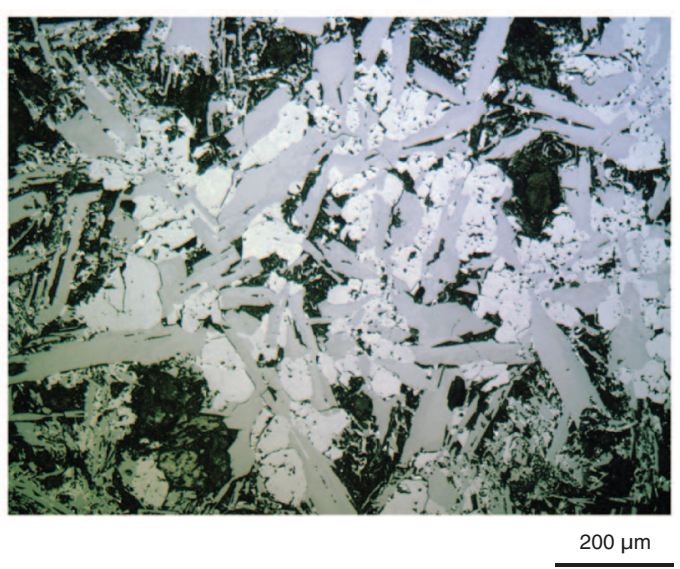


Figure F24. Downhole variation in degree of alteration, primary mineral alteration percentage for groundmass (GM) and phenocryst plagioclase and for pyroxene (based on thin section descriptions), proportion of glass preserved, vein thickness, and vein and vesicle fill (based on thin section description), Hole U1350A. alt = alteration.

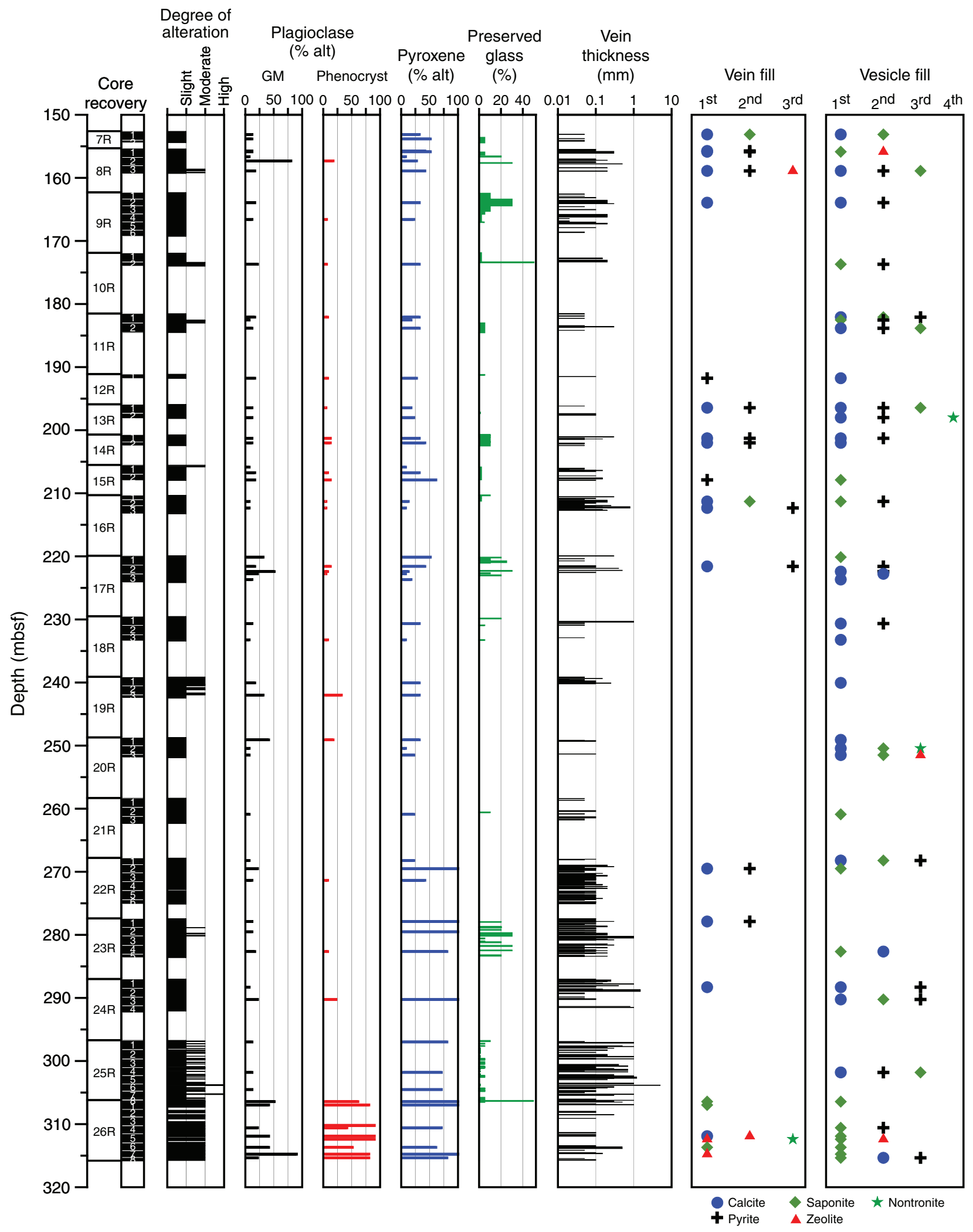


Figure F25. Downhole variation in degree of alteration based on examination of thin sections and the proportion of reflective versus nonreflective minerals, Hole U1350A. Red dashed lines = unit and subunit boundaries (see "Igneous petrology"). Higher alteration degrees (gray shaded areas) may correlate with changes in the lithology, from massive lavas to pillow lavas.

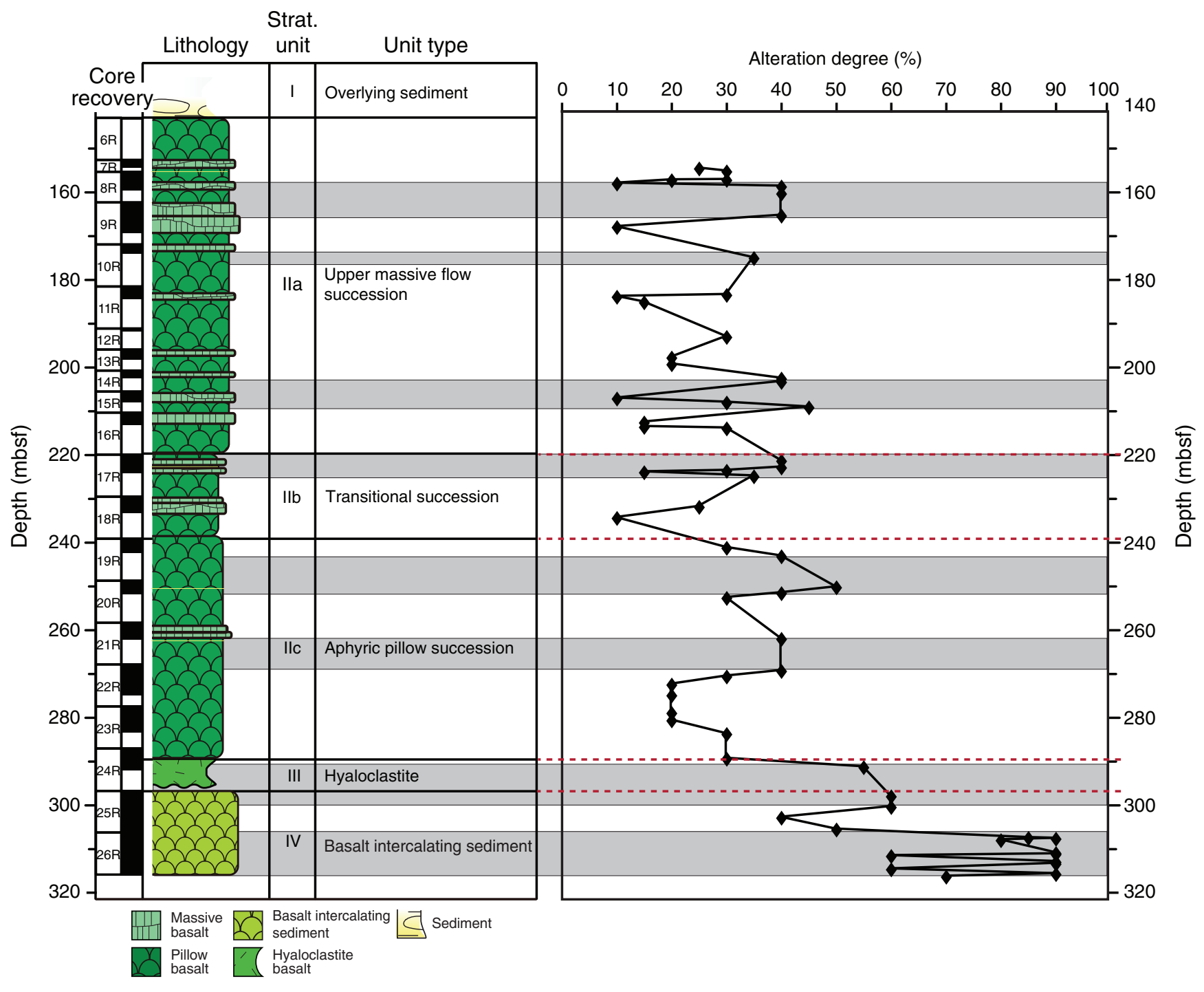


Figure F26. A-C. Photomicrographs of partially altered plagioclase phenocryst, Hole U1350A (Thin Section 332; Sample 324-U1350A-26R-6, 68-71 cm). In A, brown clay alteration is present in the inner part of the plagioclase, and green clay minerals replace plagioclase along the edges. In B, gray to yellow plagioclase (the firstorder yellow color likely relates to an overly great thickness of the slide); the lower birefringence mineral may be sanidine. In $\mathrm{C}$, nonreflective clay minerals and the slightly higher reflectance of plagioclase relative to the sanidine are visible. A is under plane-polarized light; B is under cross-polarized light; C is under reflected light.
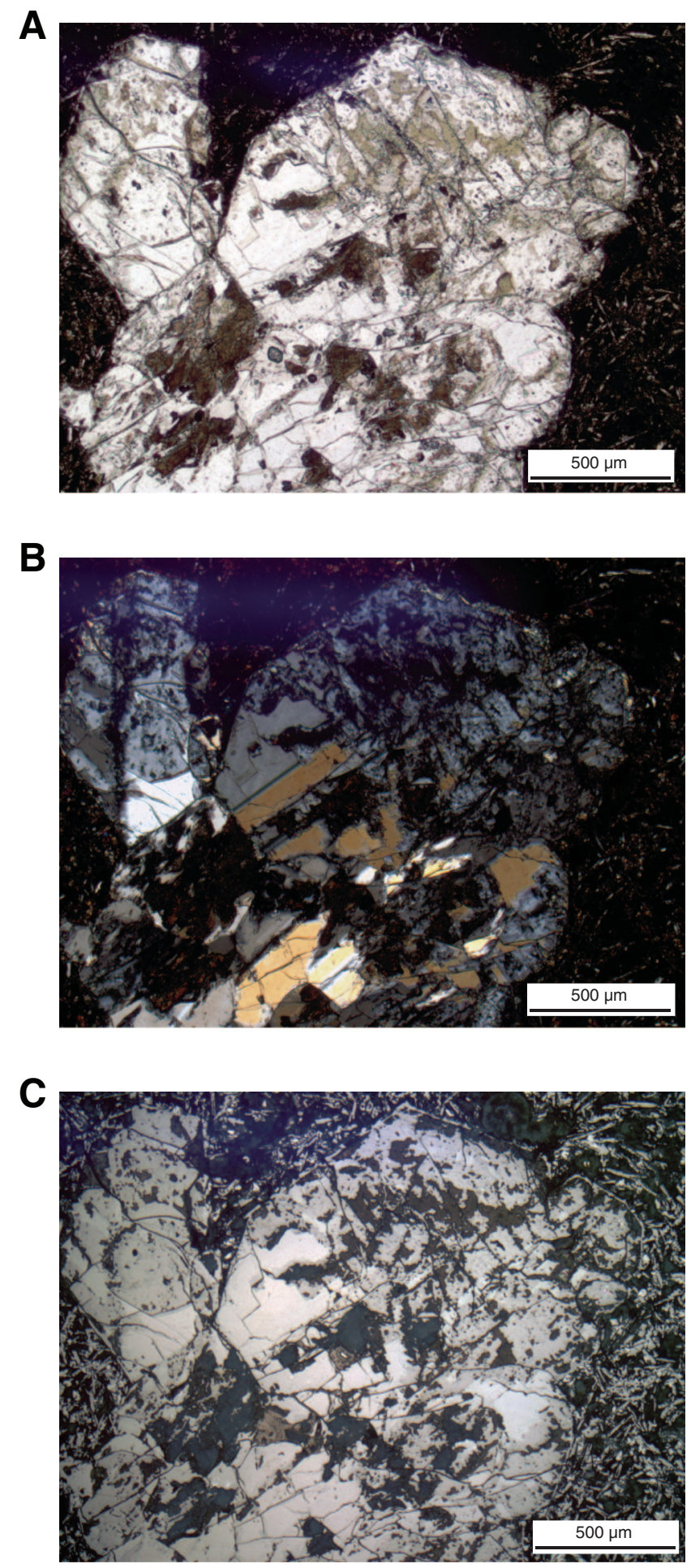
Figure F27. A. Photomicrograph of olivine phenocrysts with complete replacement by saponite and calcite, Hole U1350A (Thin Section 281; Sample 324-U1350A-14R-1, 56-60 cm). B. Photomicrograph of an olivine phenocryst completely replaced by saponite (Thin Section 306; Sample 324-U1350A-22R-3 117-119 cm). A is under cross-polarized light; B is under plane-polarized light.
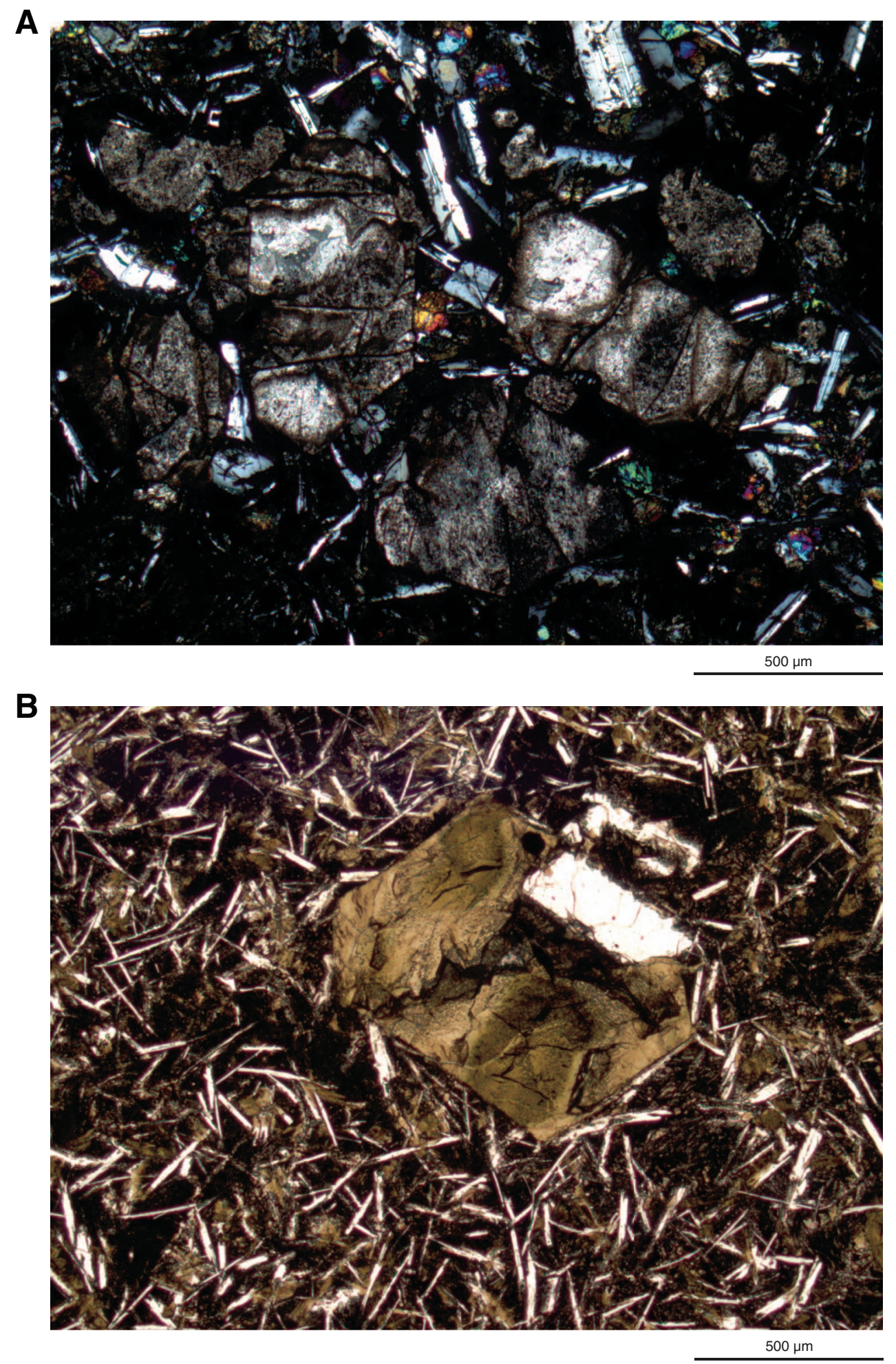
Figure F28. A, B. Photomicrographs of groundmass altered to brown clays with disseminated calcite, Hole U1350A (Thin Section 265; Sample 324-U1350A-7R-1, 122-123 cm). A is under plane-polarized light; B is under cross-polarized light.
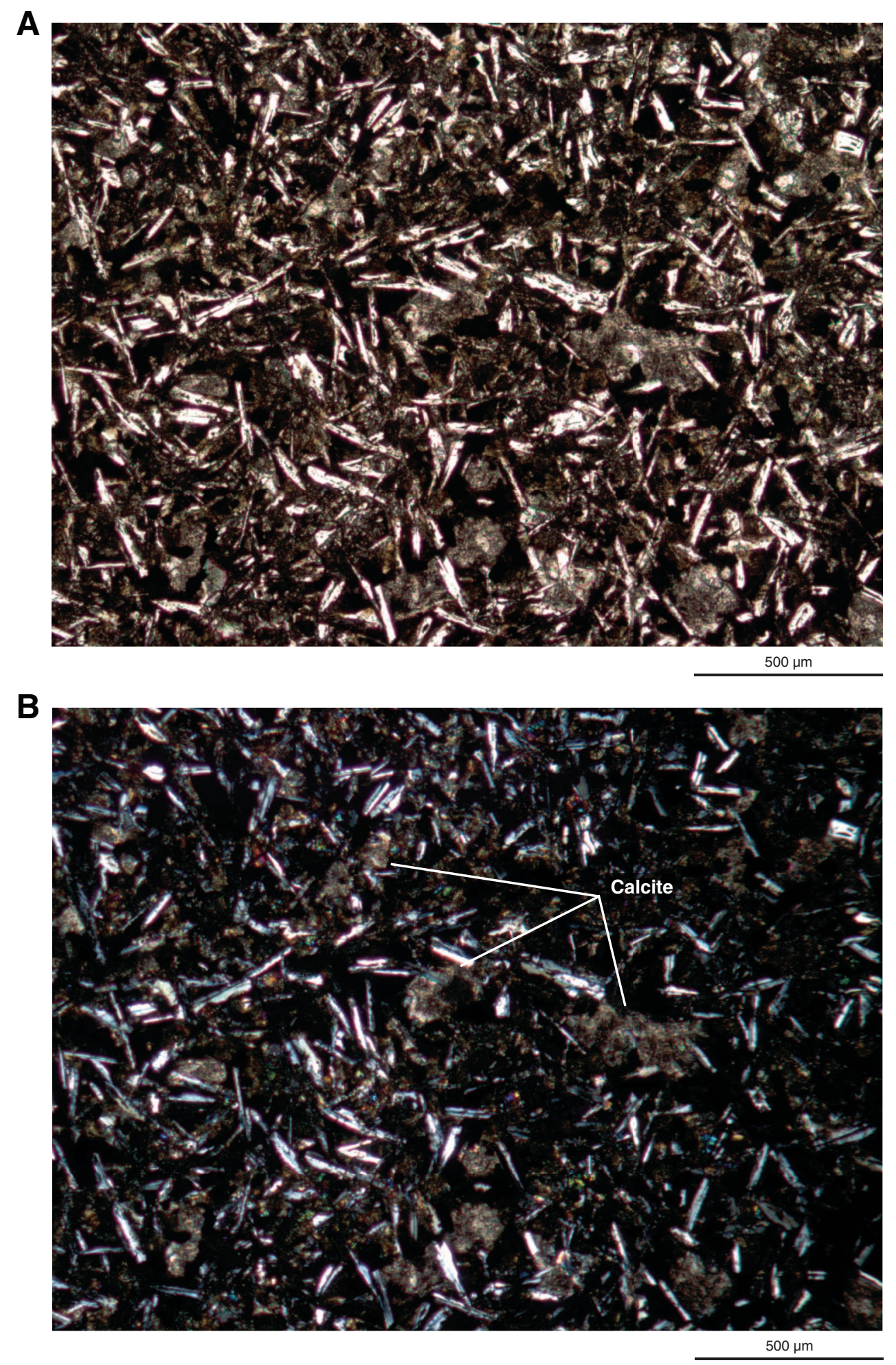
Figure F29. A, B. Photomicrographs of unaltered spherulites, Hole U1350A (Thin Section 269; Sample 324U1350A-8R-1, 133-135 cm). C, D. Photomicrographs of altered spherulites (Thin Section 320; Sample 324U1350A-25R-8, 26-29 cm). A and C are under plane-polarized light; B and D are under reflected light.
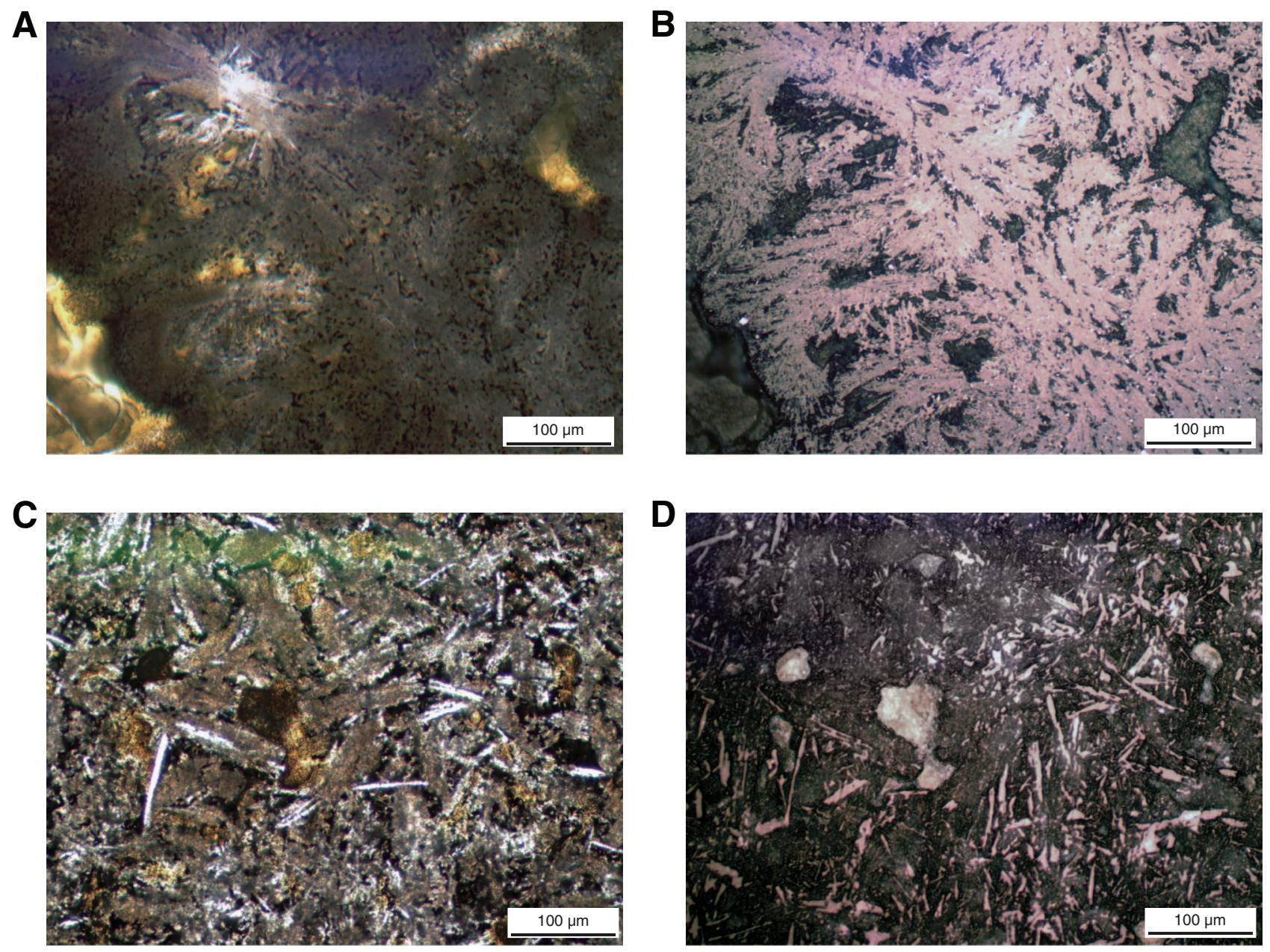
Figure F30. Photomicrographs of vesicles filled with (A) calcite, (B) calcite and pyrite (Thin Section 277; Sample 324-U1350A-11R-2, 80-83 cm), (C) calcite and zeolite (Thin Section 302; Sample 324-U1350A-20R-3, 8-11 cm), and (D) saponite, Hole U1350A (Thin Section 320; Sample 324-U1350A-25R-8, 26-29 cm). A and D are under plane-polarized light; B is under reflected light; C is under cross-polarized light.
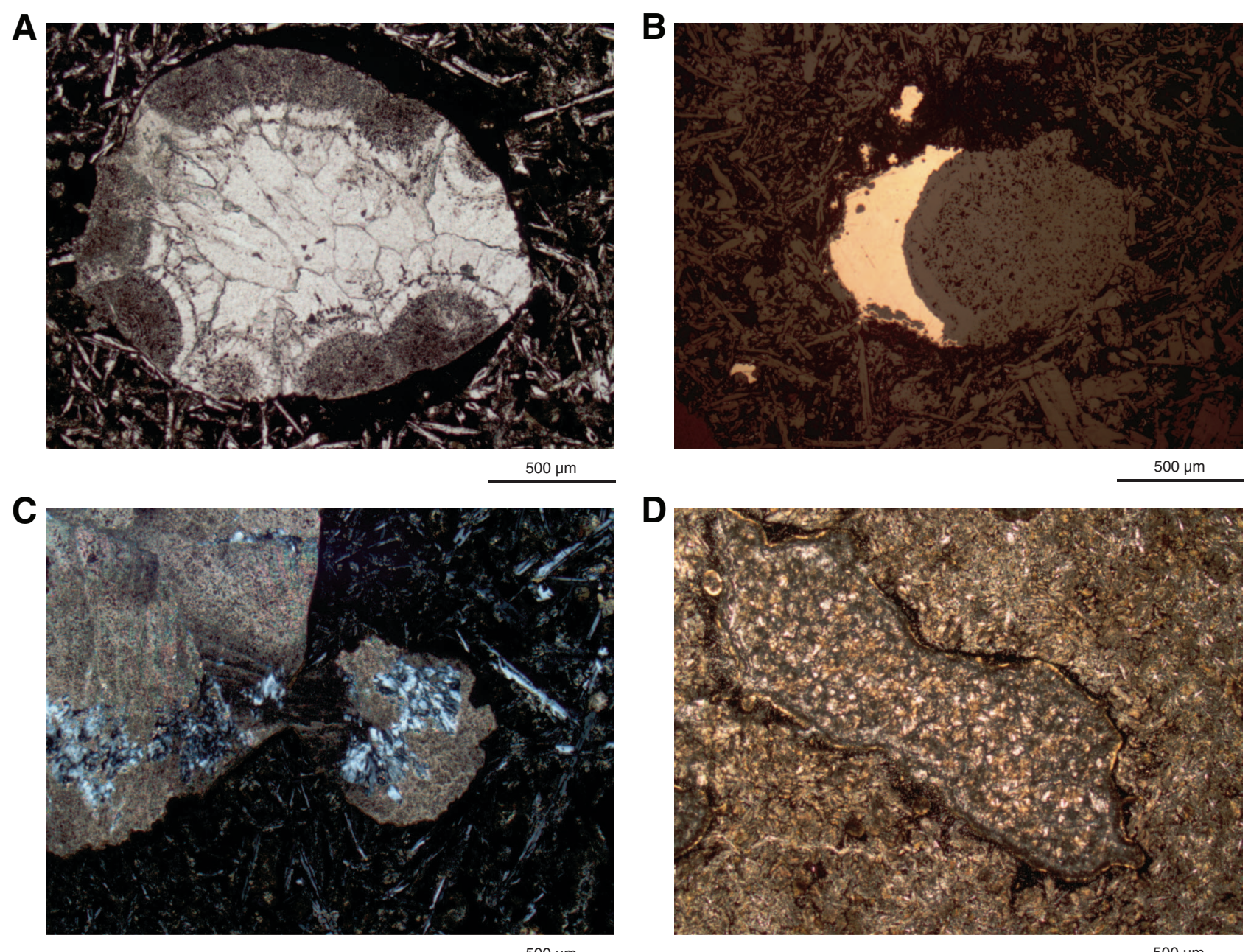

$500 \mu \mathrm{m}$

$500 \mu \mathrm{m}$ 
Figure F31. Photomicrographs of (A) a pyrite vein (Thin Section 267; Sample 324-U1350A-8R-1, 54-58 cm), (B) a cross-fiber calcite vein cutting a vein containing botryoidal calcite cemented by saponite, and (C) multiple generations of calcite and saponite veins, Hole U1350A (Thin Section 307; Sample 324-U1350A-22R-5, 81-87 cm). A is under reflected light; B and C are under plane-polarized light.

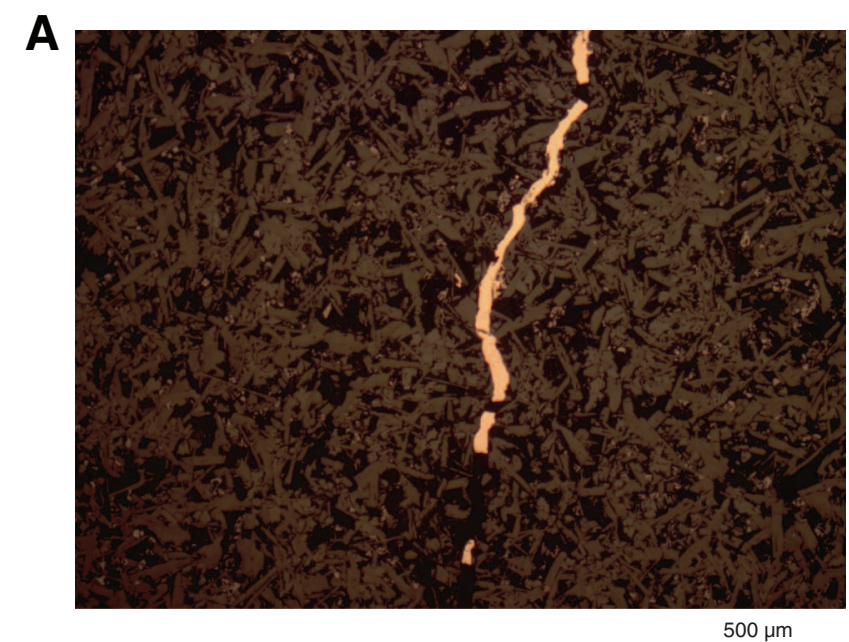

B
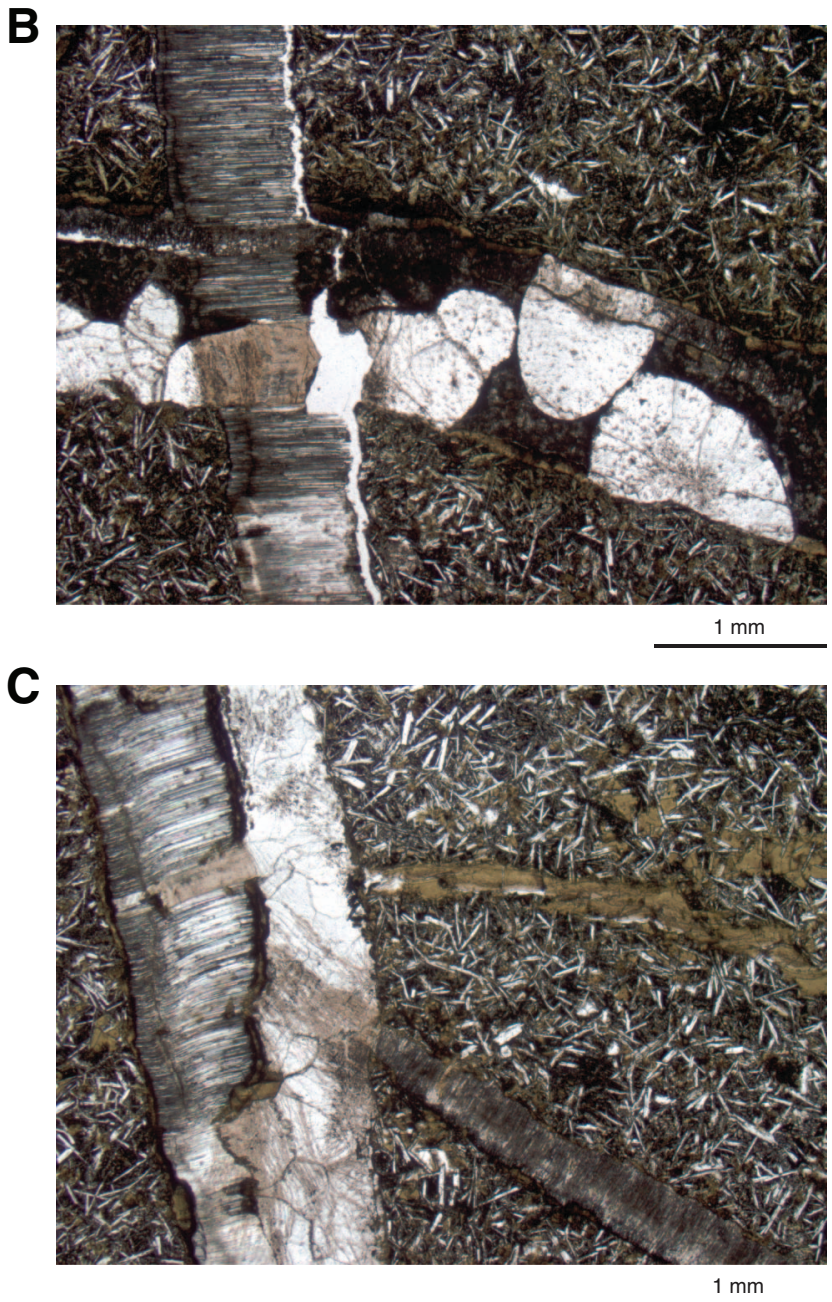
Figure F32. Core images of representative pillow structures from Sections 324-U1350A-22R-3 and 26R-3, Hole U1350A.

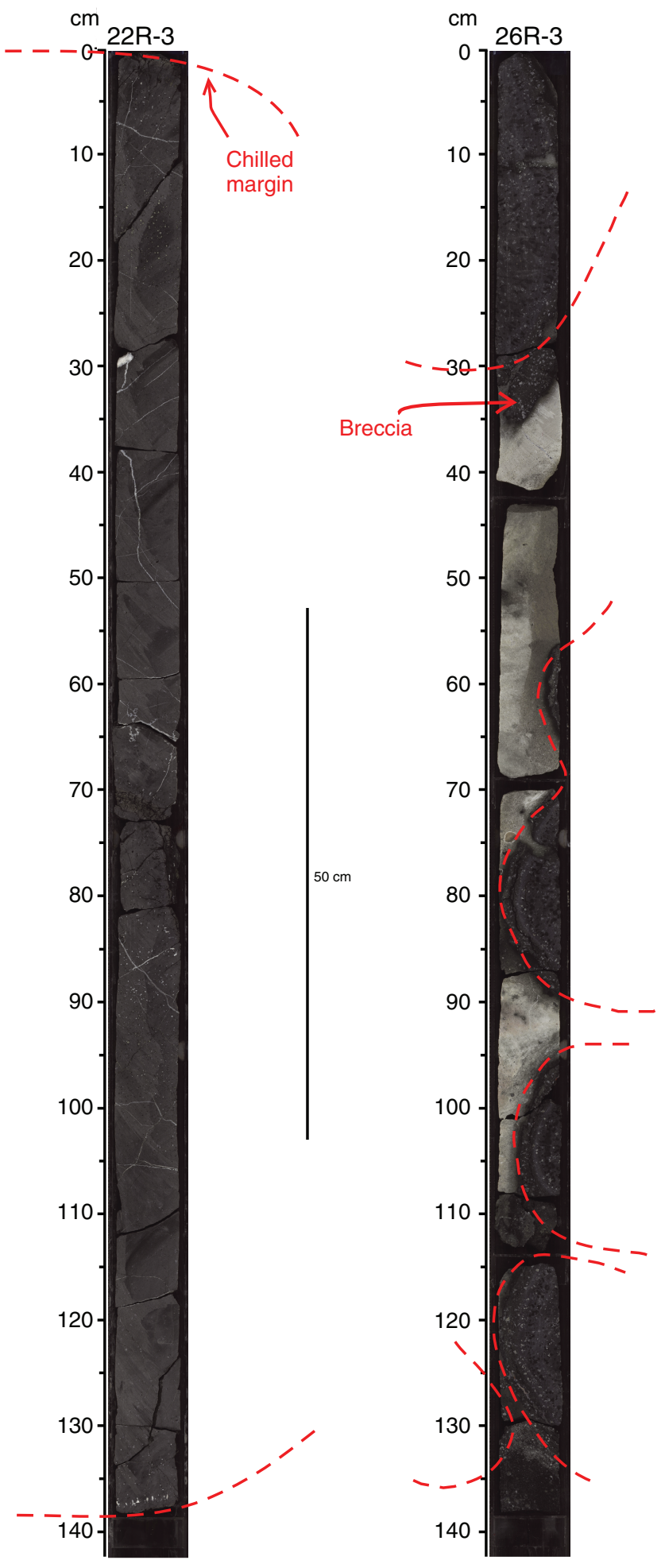


Figure F33. Core images of hyaloclastic breccia pieces, Hole U1350A. A. Interval 324-U1350A-19R-2, 11-23 cm. B. Interval 324-U1350A-19R-2, 69-92 cm.

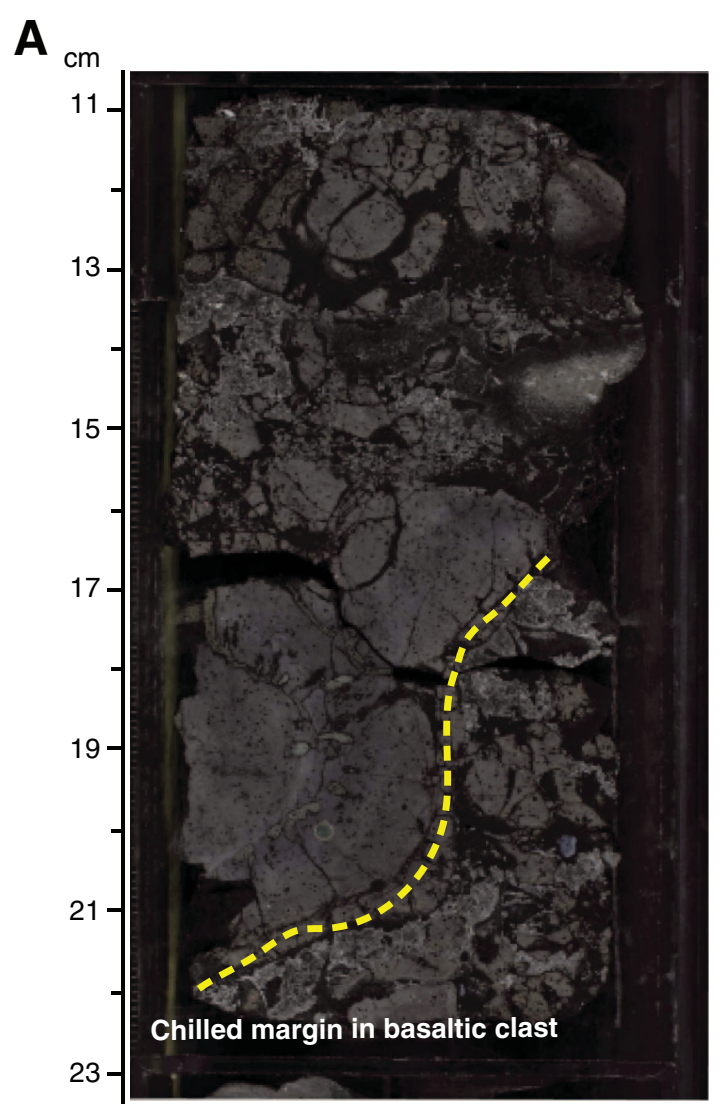

B

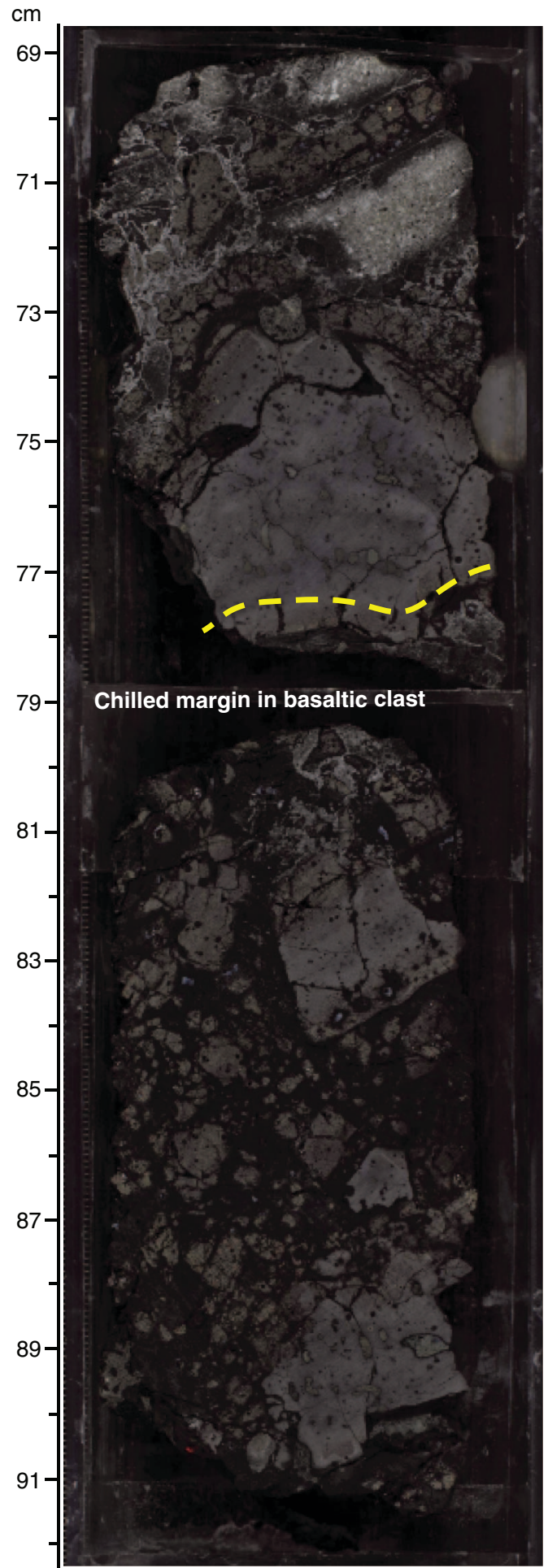


Figure F34. Core images of chilled margins in basalt pieces, Hole U1350A. A. Interval 324-U1350A-15R-2, 92.5$98.5 \mathrm{~cm}$. B. Interval 324-U1350A-20R-1, 100.0-113.5 cm.
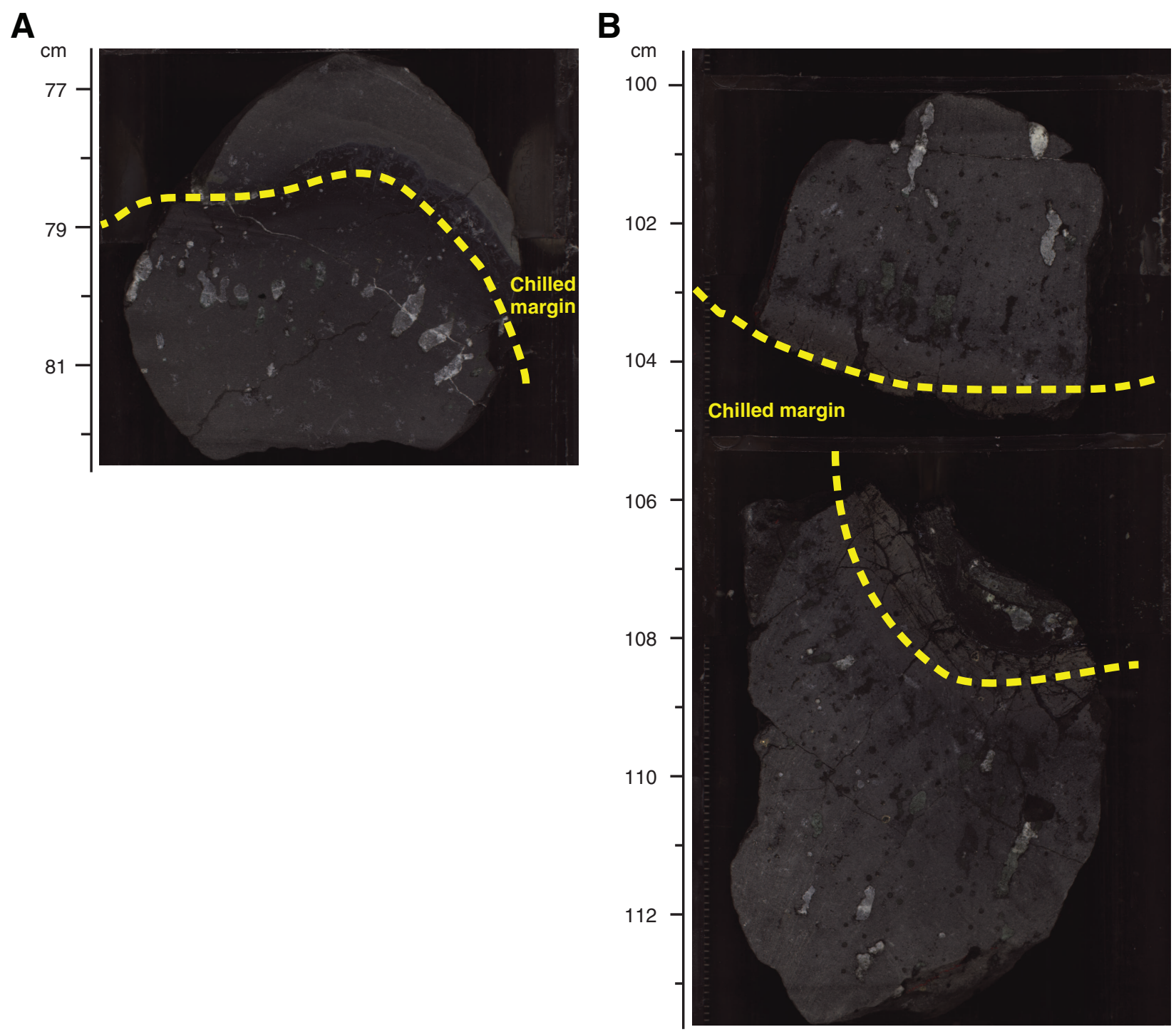
Figure F35. Core images of pipe vesicles and vesicle cylinders, Hole U1350A. A. Interval 324-U1350A-12R-1, 36.5-57.0 cm. B. Interval 324-U1350A-13R-1, 13.5-56.5 cm. C. Interval 324-U1350A-14R-2, 13.0-36.5 cm. D. Interval 324-U1350A-17R-1, 79-85 cm. E. Interval 324-U1350A-17R-1, 106-113 cm. F. Interval 324-U1350A18R-1, 77-102 cm.

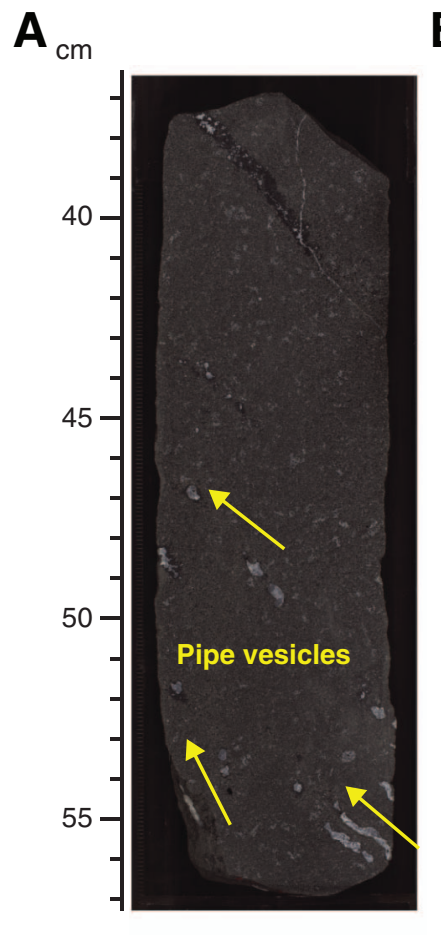

B

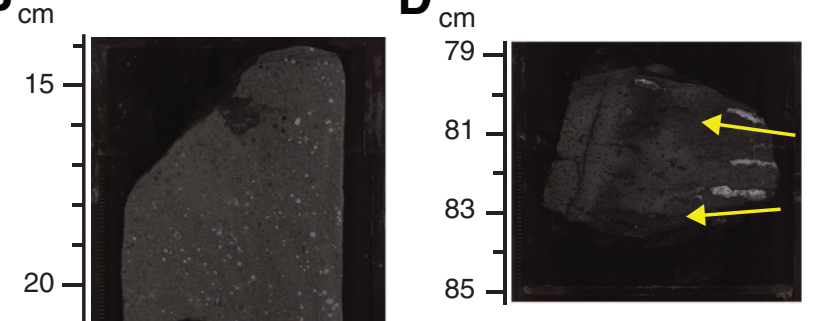

C

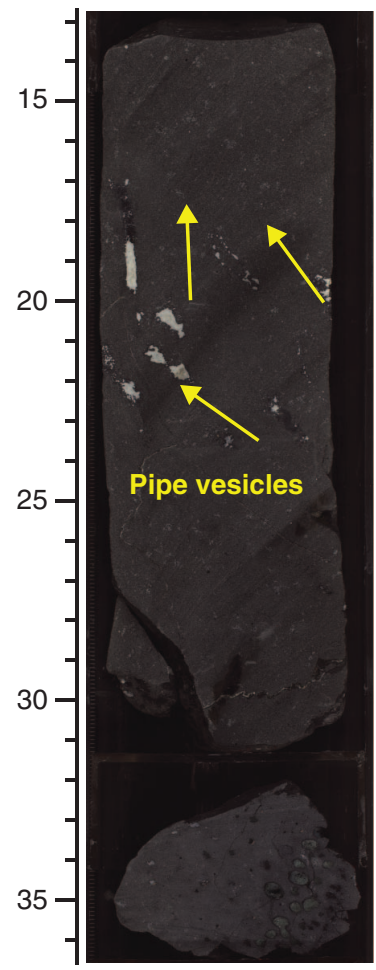

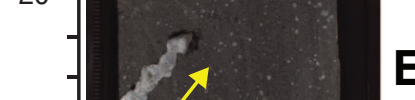

E

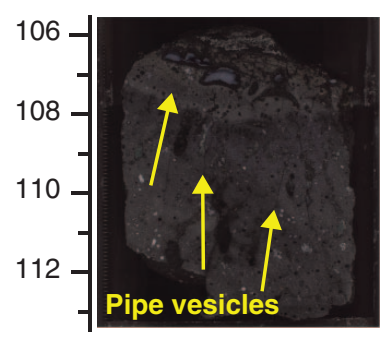

$\mathbf{F}$

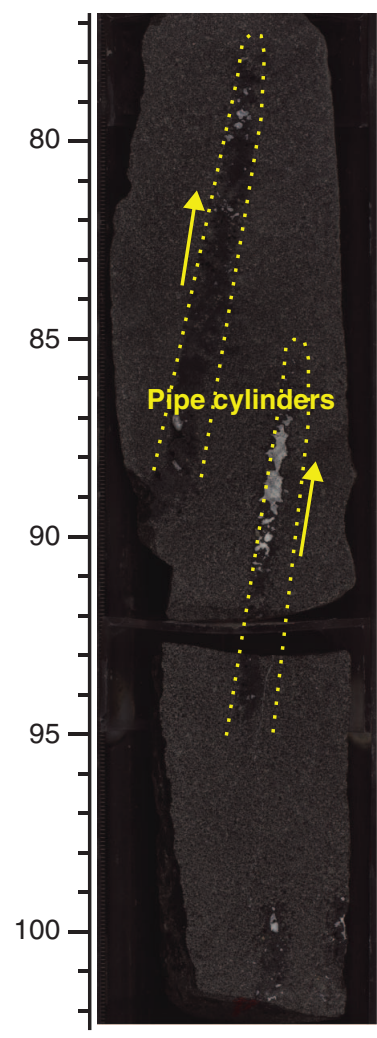


Figure F36. Core images of interpillow structures, Hole U1350A. A. Limestone between pillow basalt (interval 324-U1350A-26R-5, 48.5-101.5 cm). B. Hyaloclastic breccias between pillow basalt (interval 324-U1350A-24R-2, $21.5-50.5 \mathrm{~cm})$.

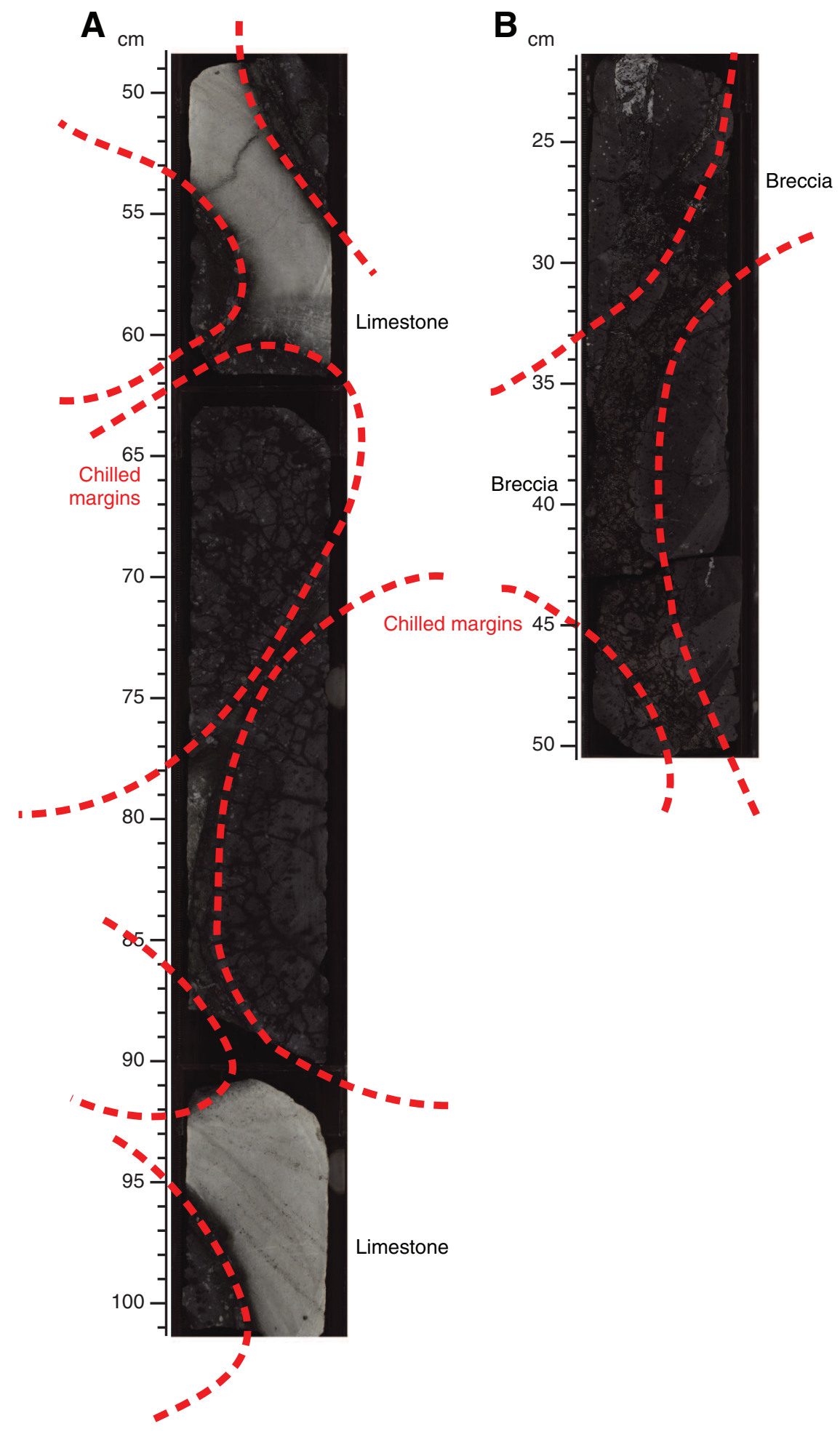


Figure F37. Relationships between lithology and vein and joint dip, Hole U1350A.

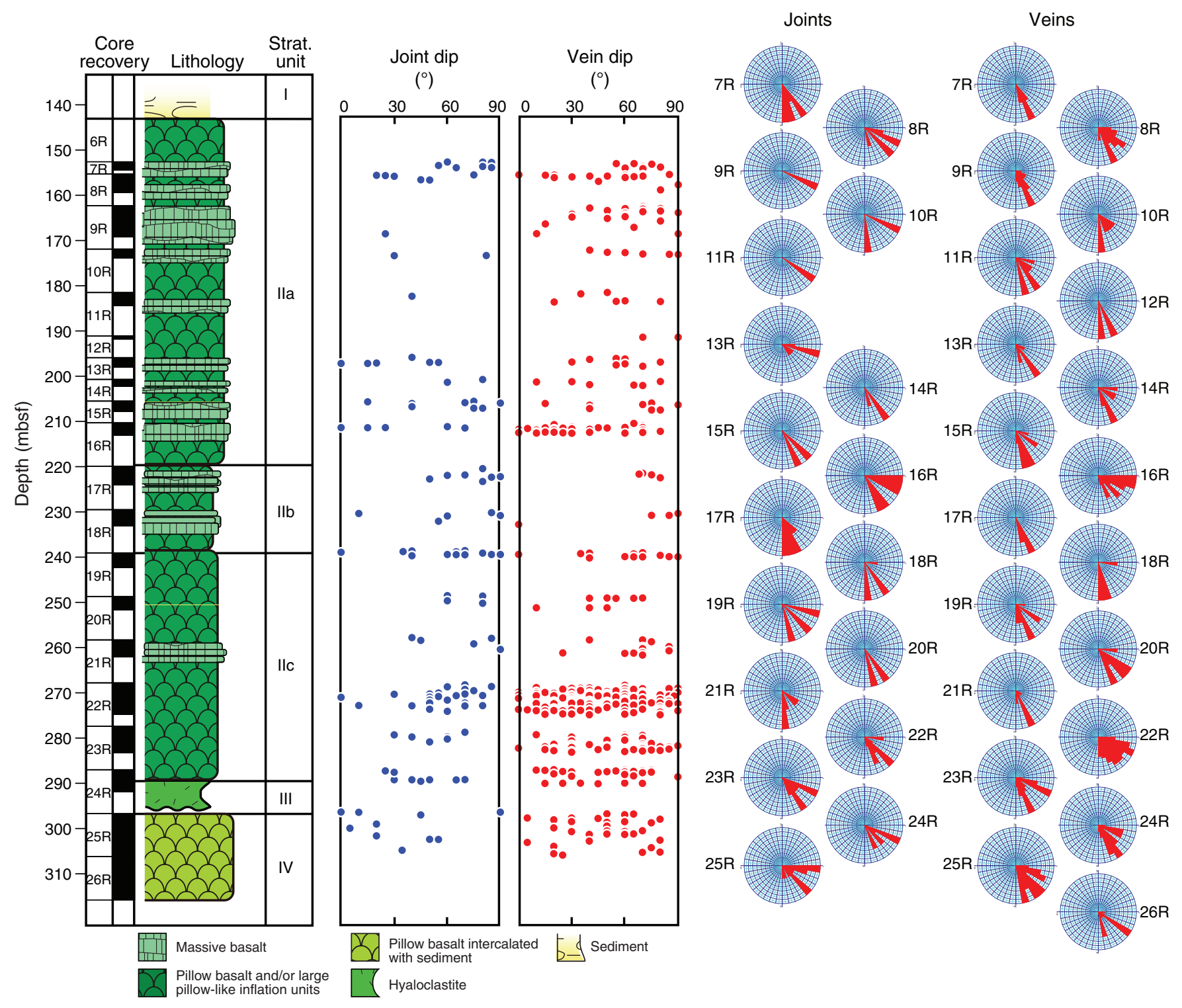


Figure F38. A, B. Photomicrographs of cross-fibers of needlelike calcites growing perpendicular to vein walls at (A) $1.25 \times$ and (B) $2.5 \times$ magnification, Hole U1350A (Thin Section 289; Sample 324-U1350A-16R-3, 71-74 cm). Yellow arrows $=$ orientation in core. Cross-polarized light.
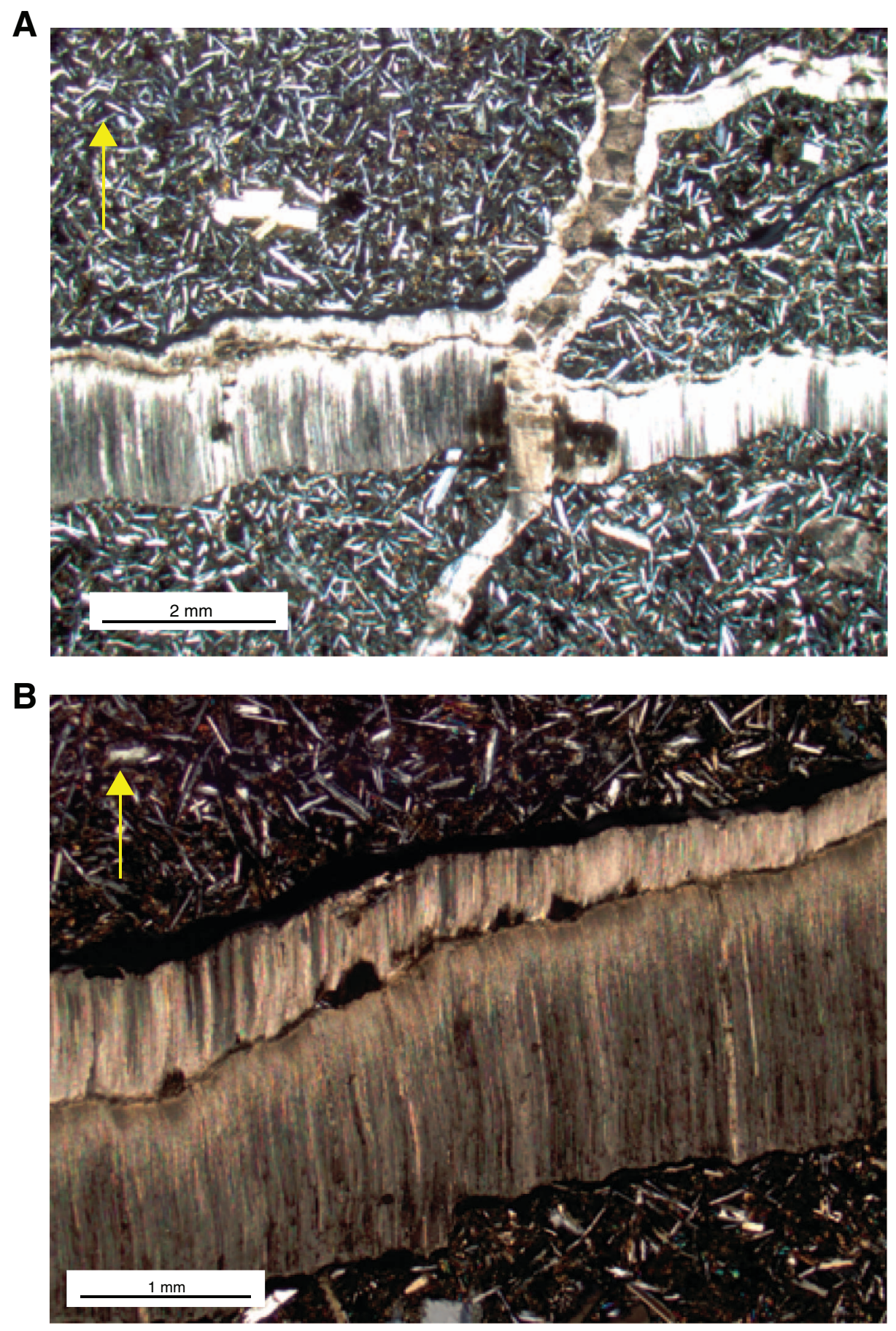
Figure F39. Distribution of vein thickness, veins, and joints with depth, Hole U1350A.

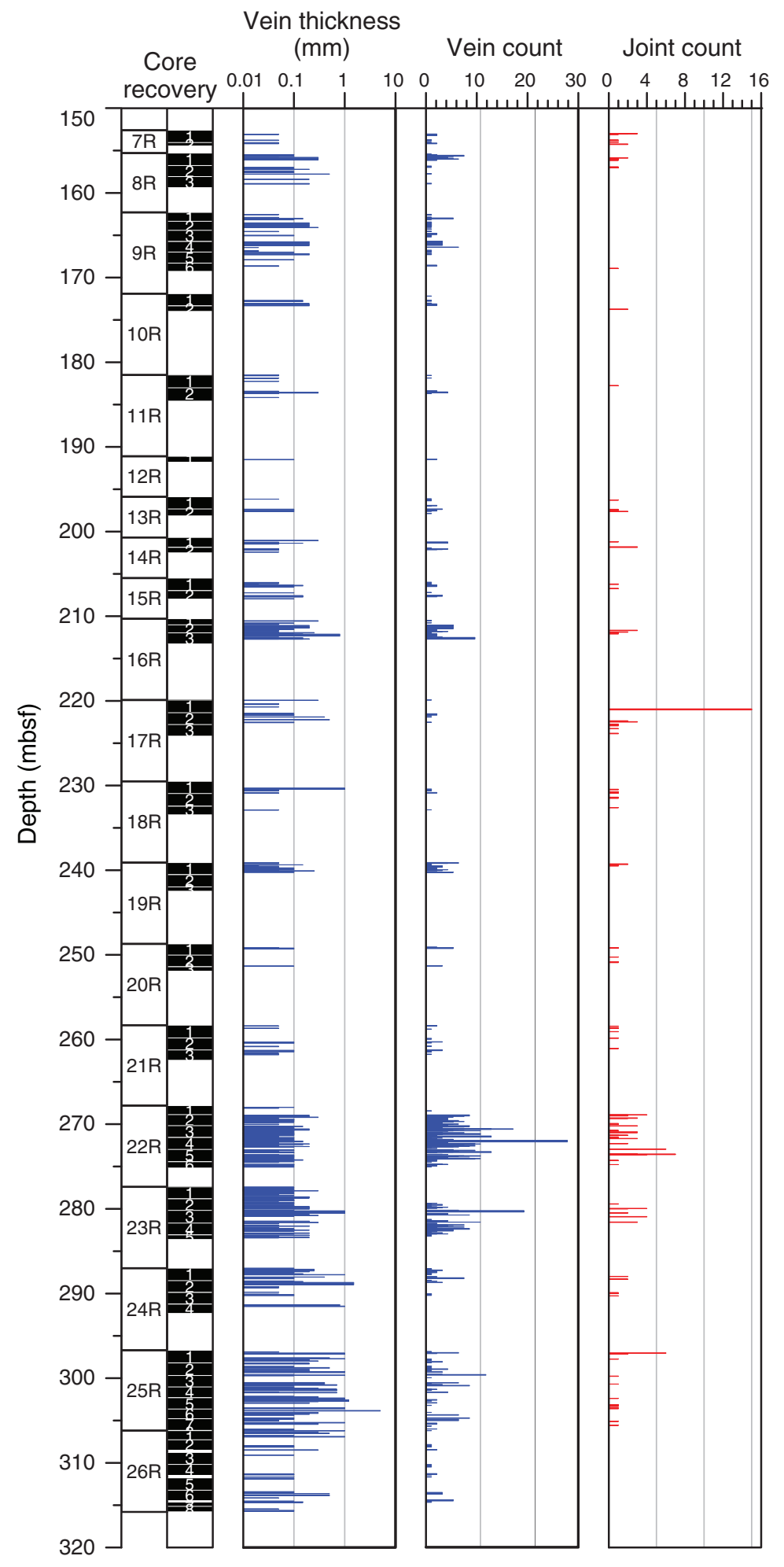


Figure F40. Diagram of total alkalis vs. silica with Le Maitre et al.'s (1989) classification of volcanic rock types. Heavy dashed line = division of data for tholeiitic and alkalic lavas of Hawaii (Macdonald and Katsura, 1964; Macdonald, 1968). Values normalized to $100 \mathrm{wt} \%$ totals. OJP = Ontong Java Plateau (data from Tejada et al., 1996, 2002; Fitton and Godard, 2004), EPR = East Pacific Rise (data from Sinton et al., 1991; Bach et al., 1994; Mahoney et al., 1994), Nazca-ESC = Nazca Ridge and Easter Seamount Chain (Ray et al., unpubl. data).

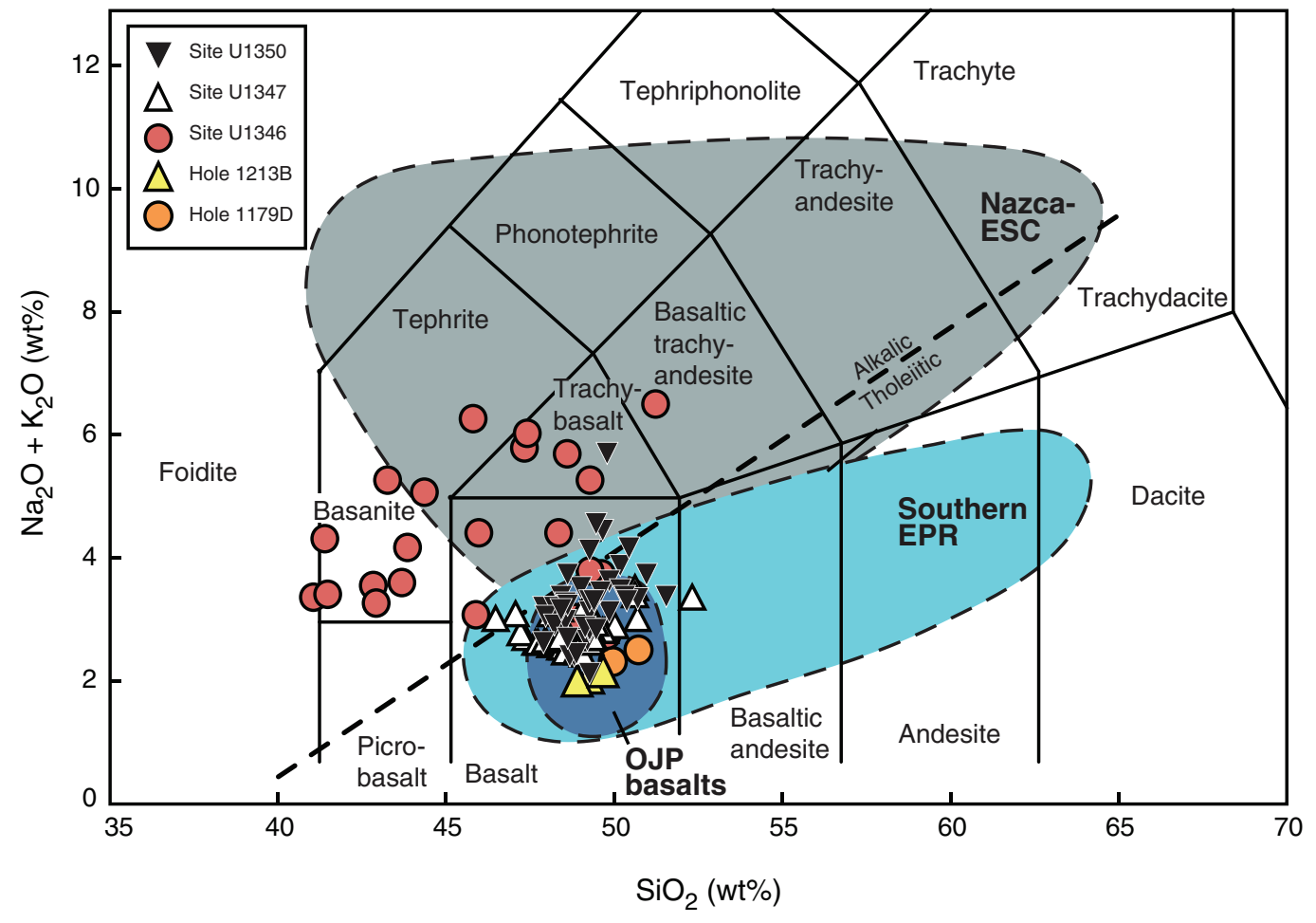


Figure F41. Downhole variation of $(\mathbf{A}) \mathrm{K}_{2} \mathrm{O}$, (B) $\mathrm{TiO}_{2}$, (C) $\mathrm{Mg \# ,} \mathrm{(D)} \mathrm{Cr}$, and (E) $\mathrm{Zr} / \mathrm{Ti}$ in Site U1350 basement. Dashed lines $=$ unit boundaries. Major element data normalized to $100 \mathrm{wt} \%$ totals. $\mathrm{Mg} \#=100 \times\left[\mathrm{Mg}^{2+} /\left(\mathrm{Mg}^{2+}+\right.\right.$ $\left.\mathrm{Fe}^{2+}\right)$ ], assuming that $\mathrm{Fe}_{2} \mathrm{O}_{3} / \mathrm{FeO}=0.15$. See "Paleontology" and "Igneous petrology" for description of stratigraphic units.

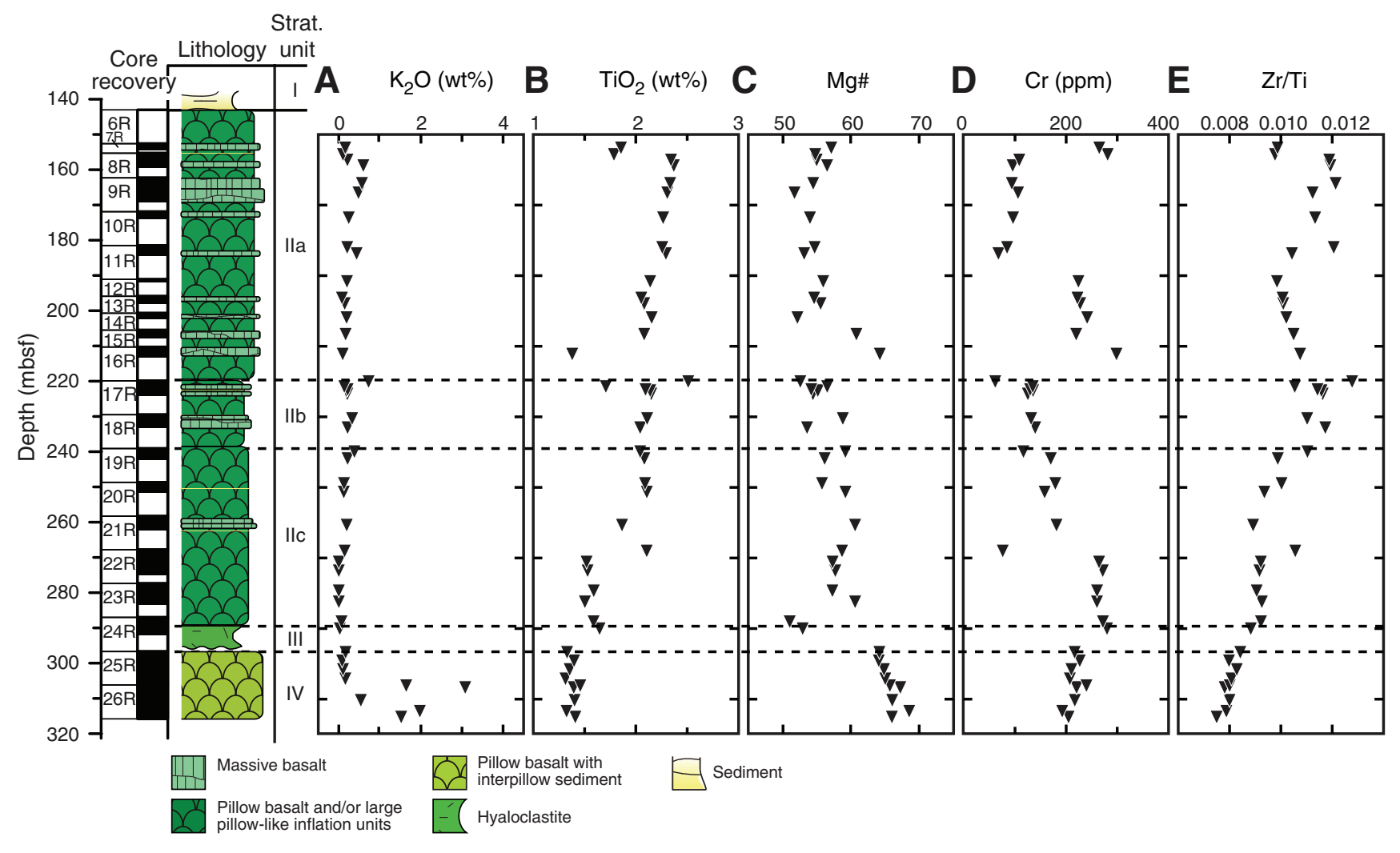


Figure F42. Diagrams of $\mathrm{TiO}_{2}$ vs. (A) $\mathrm{CaO} / \mathrm{Al}_{2} \mathrm{O}_{3},(\mathbf{B}) \mathrm{Mg \#}$, (C) $\mathrm{Cr}$, (D) $\mathrm{Zr}$, and (E) Sr. OJP = Ontong Java Plateau (data from Tejada et al., 1996, 2002; Fitton and Godard, 2004), EPR = East Pacific Rise (data from Sinton et al., 1991; Bach et al., 1994; Mahoney et al., 1994), Nazca-ESC = Nazca Ridge and Easter Seamount Chain (data from Ray et al., submitted).

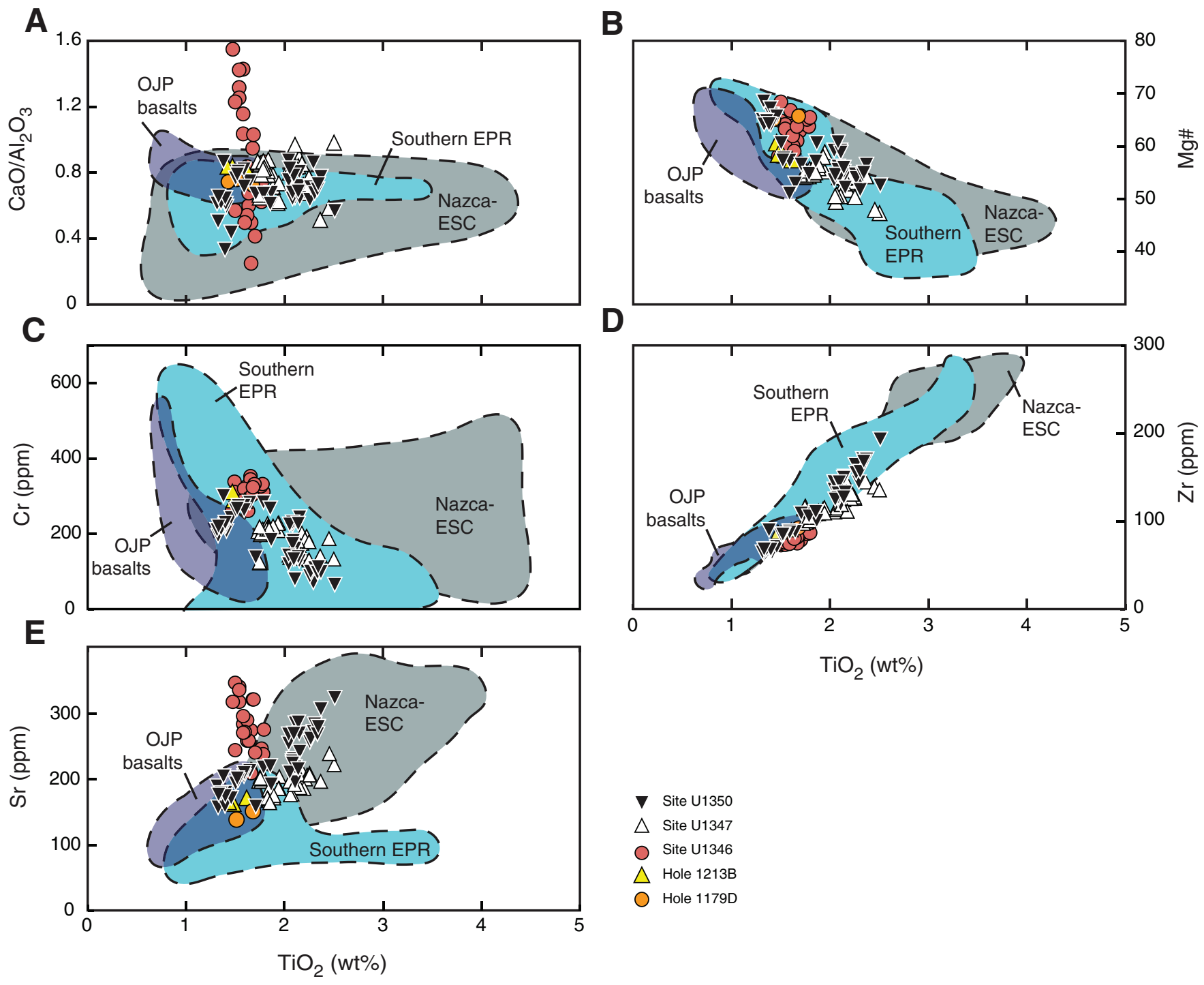


Figure F43. Whole-round physical property data summary, Hole U1350A. For more details about data filtering, see "Physical properties" in the "Methods" chapter. For a full lithologic description of the stratigraphic units, see "Igneous petrology." NGR = natural gamma radiation, MS = magnetic susceptibility, GRA = gamma ray attenuation.

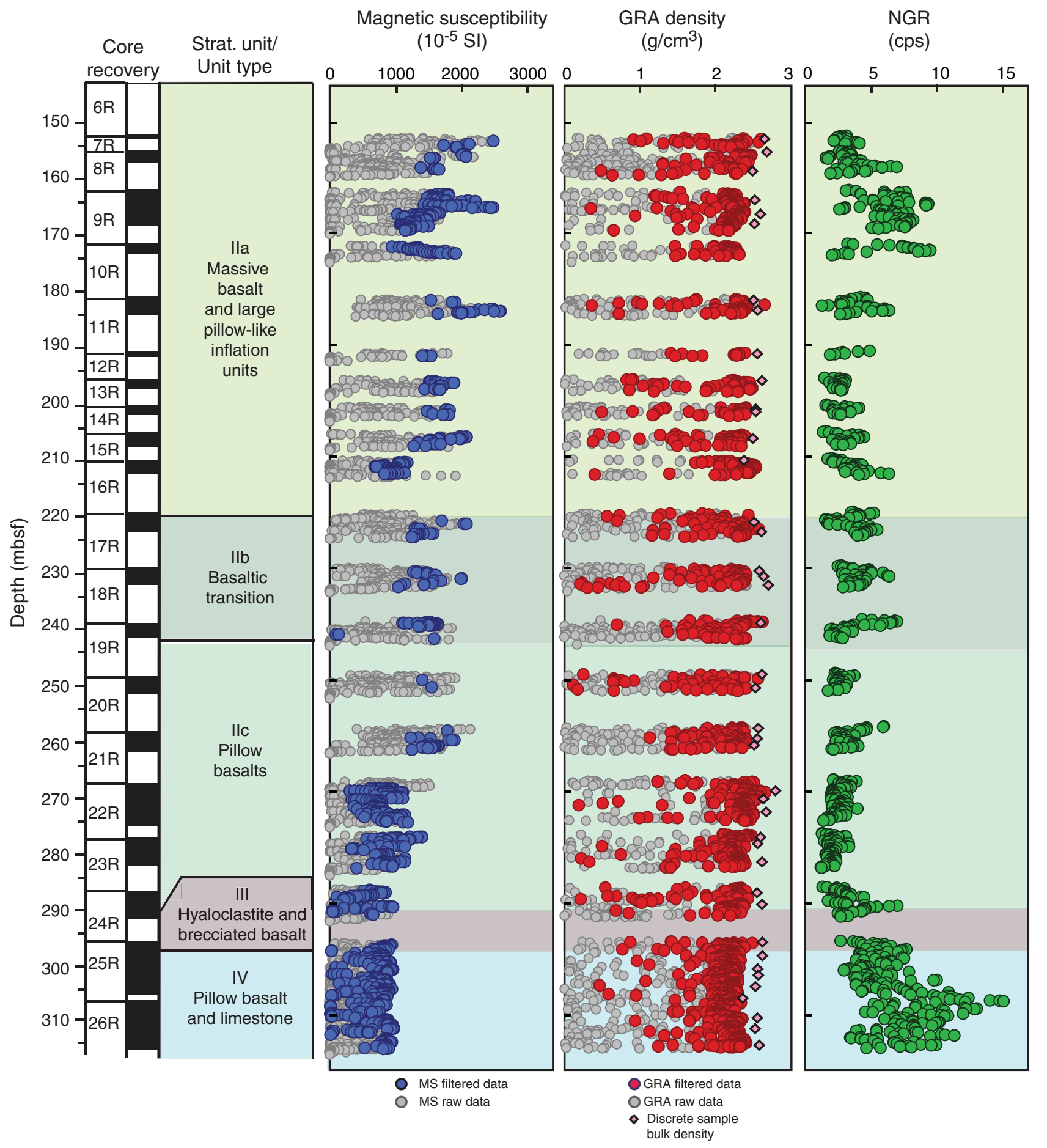


Figure F44. Selected discrete sample measurements, Hole U1350A. Red dashed line connects measurements of bulk density for ease of comparison with $P$-wave velocity measurements. For a full lithologic description of the stratigraphic units, see "Igneous petrology." GRA = gamma ray attenuation.

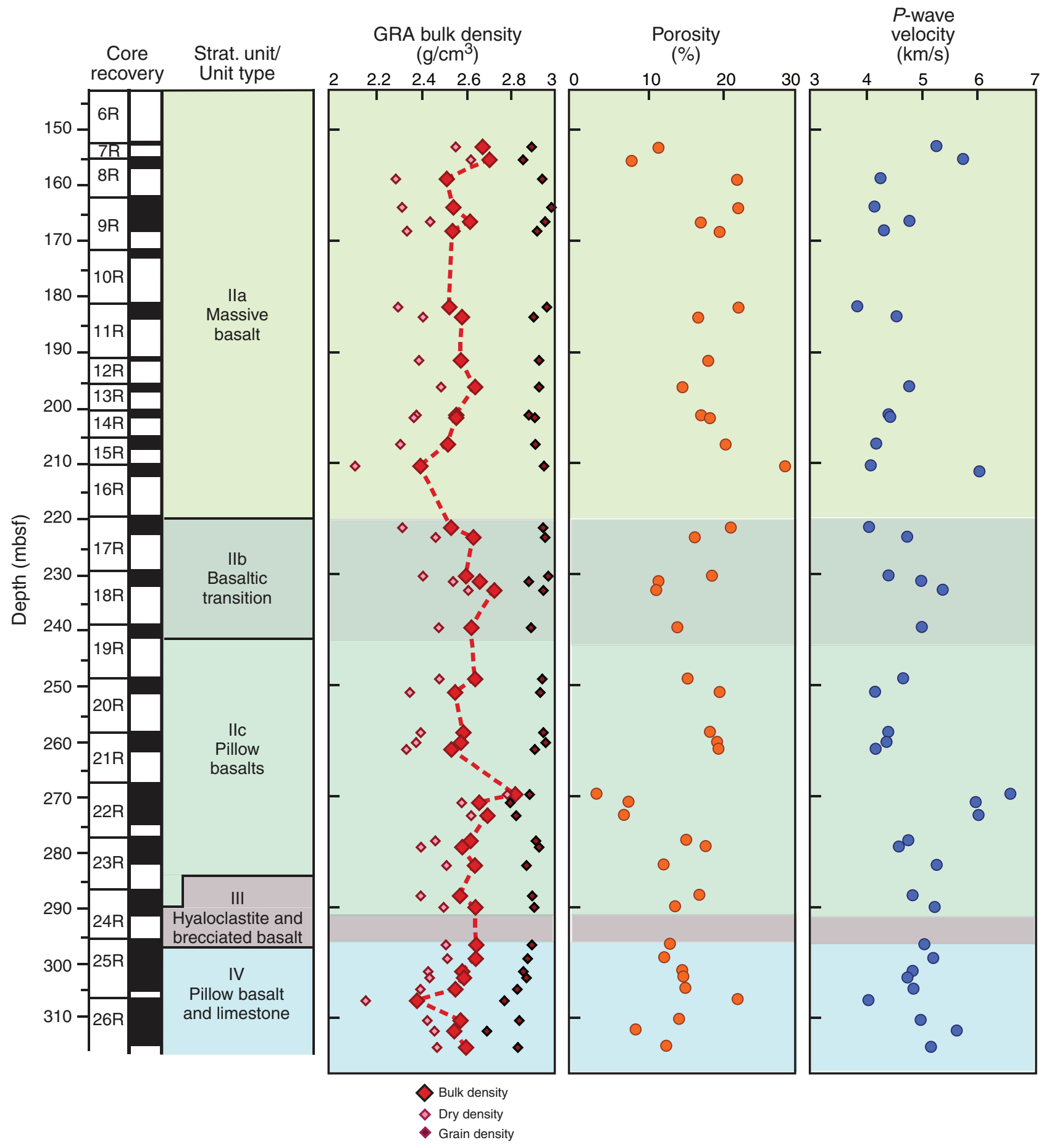


Figure F45. Plots of $P$-wave velocity vs. (A) bulk density and (B) porosity, Hole U1350A. For a full lithologic description of the stratigraphic units, see "Igneous petrology."

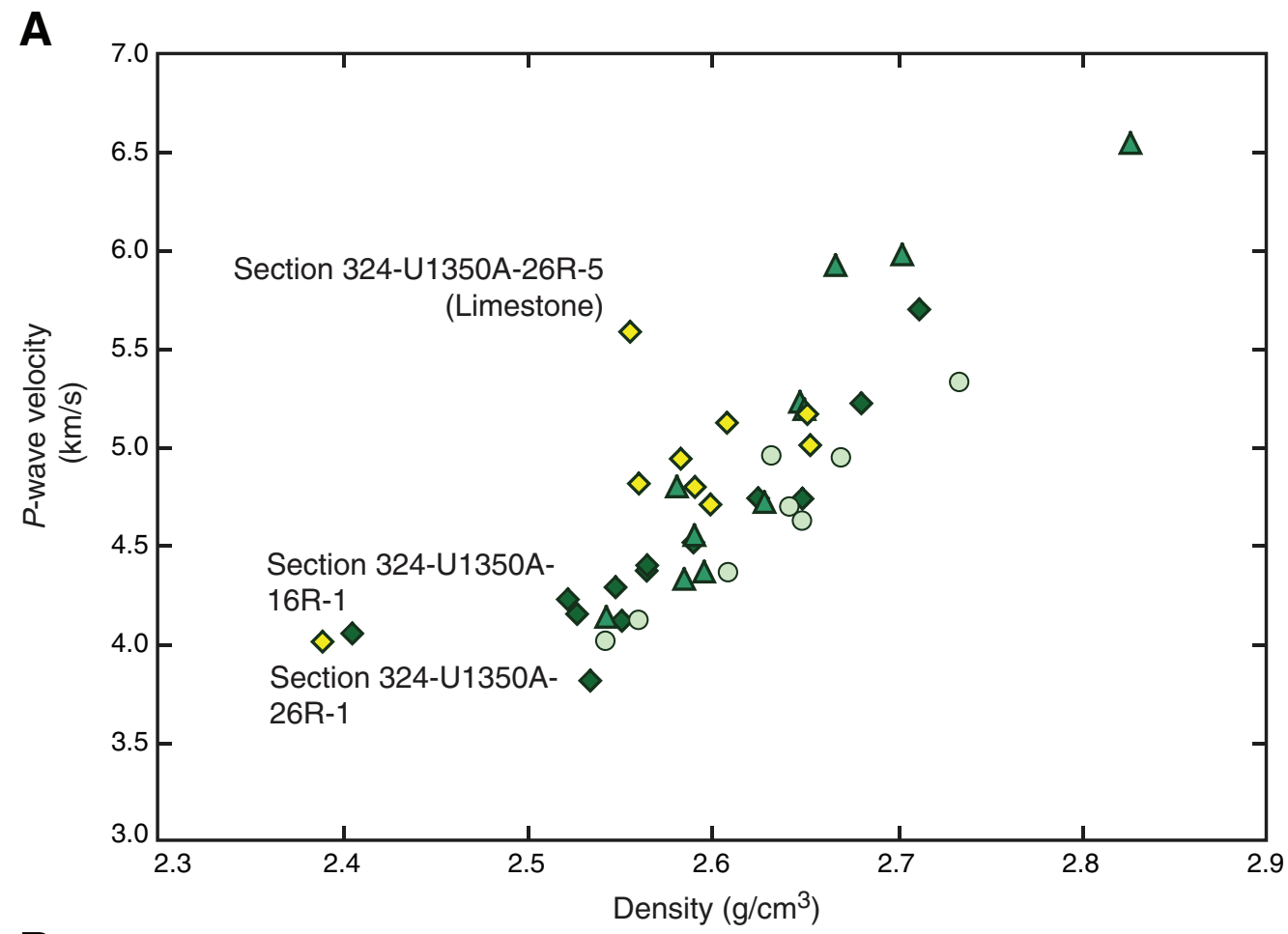


Figure F46. Example orthogonal vector plots of $(\mathbf{A}, \mathbf{B})$ alternating-field and $(\mathbf{C}-\mathbf{E})$ thermal demagnetizations, Hole U1350A. Open circles = inclinations, solid circles = declinations, NRM = natural remanent magnetization.

A

Sample 324-U1350A-21R-2, 67-69 cm

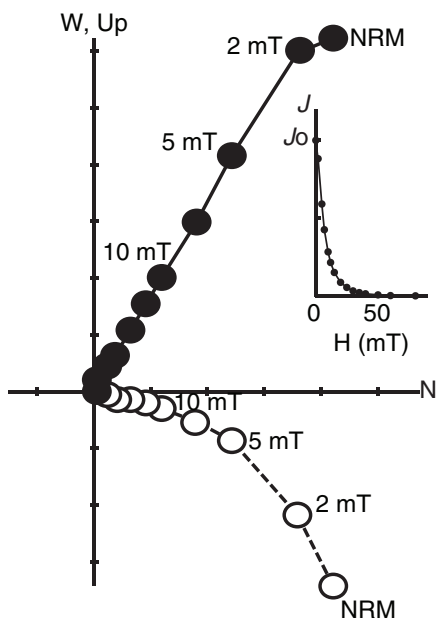

D Sample 324-U1350A-21R-1, 35-37 cm

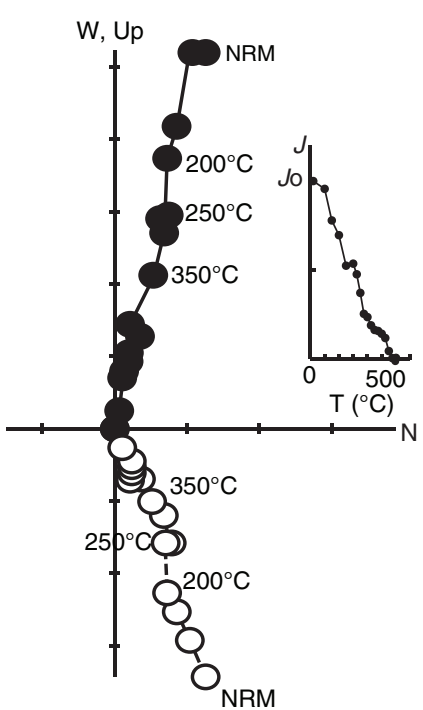

B Sample 324-U1350A-26R-1, 78-80 cm

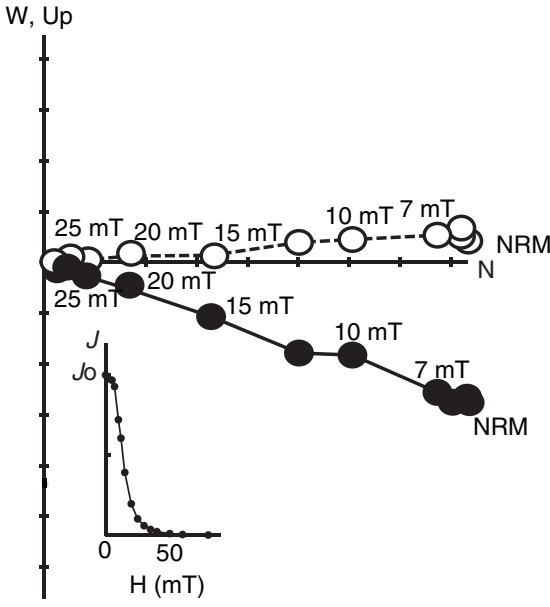

E

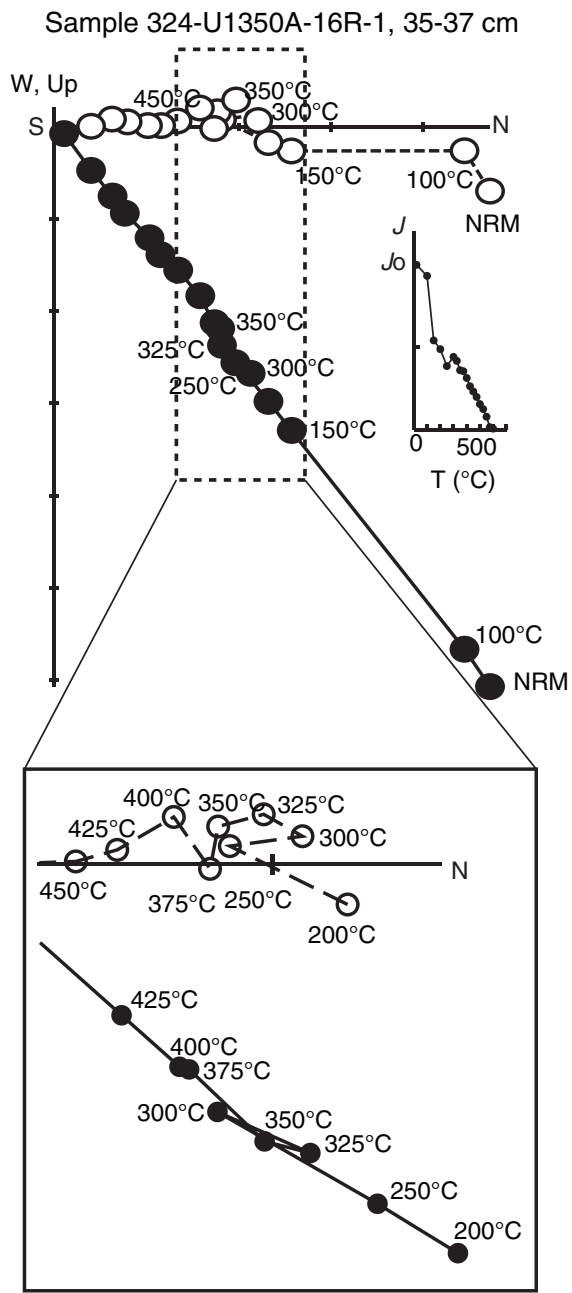

Sample 324-U1350A-18R-1, 97-99 cm

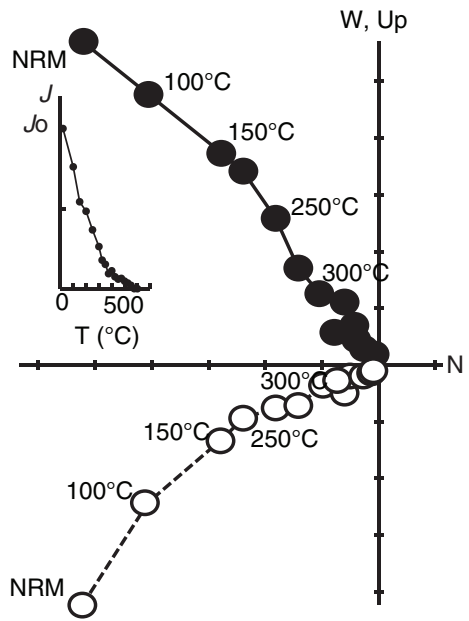


Figure F47. Demagnetization results for volcaniclastic and basalt samples vs. depth, Hole U1350A. AF demag $=$ alternating-field demagnetization, $\mathrm{TH}$ demag $=$ thermal demagnetization. Dotted lined $=$ separations between igneous units. See "Igneous petrology" for stratigraphic unit descriptions.

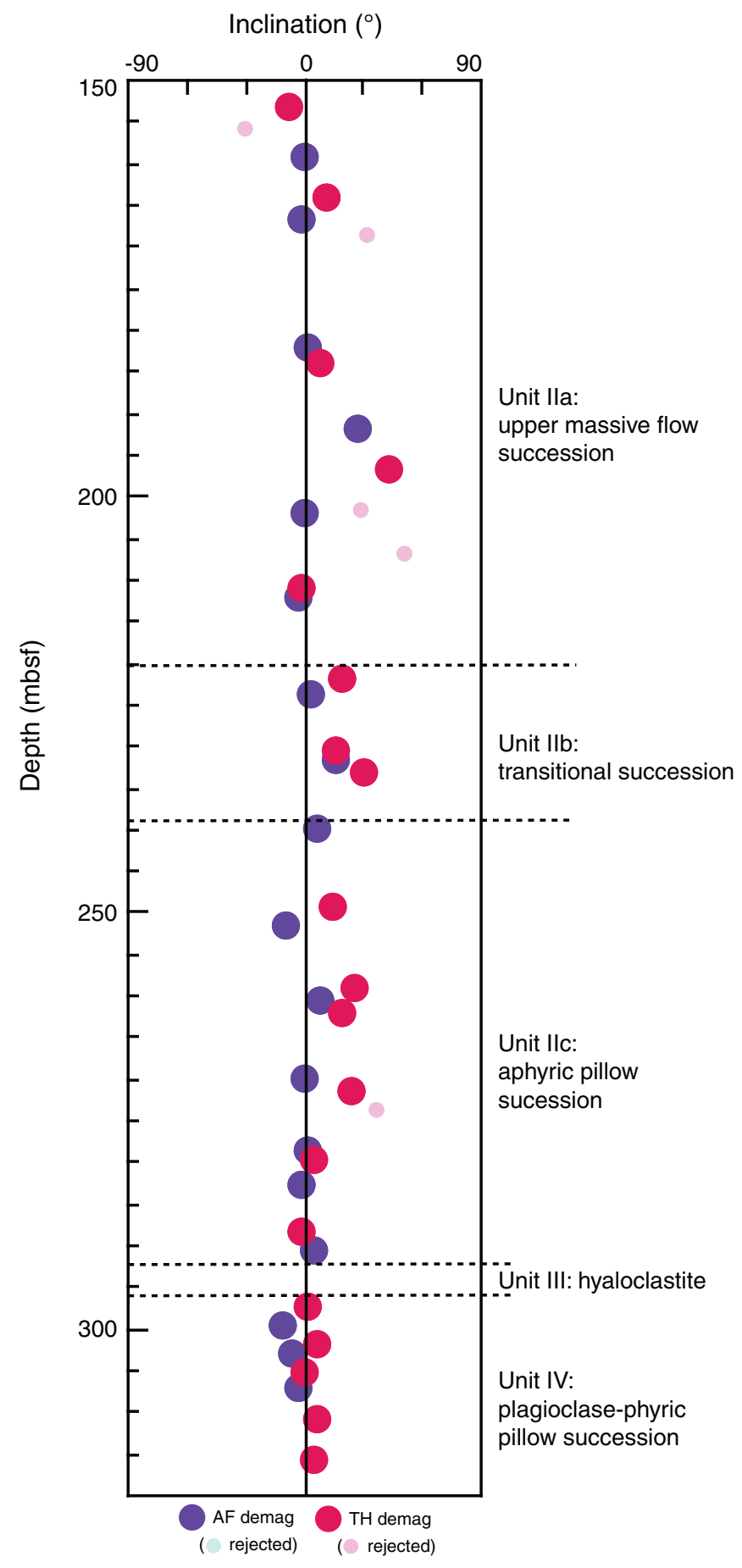


Figure F48. Filtered surface and head tension records for the two descents and ascents attempted in Hole U1350A.

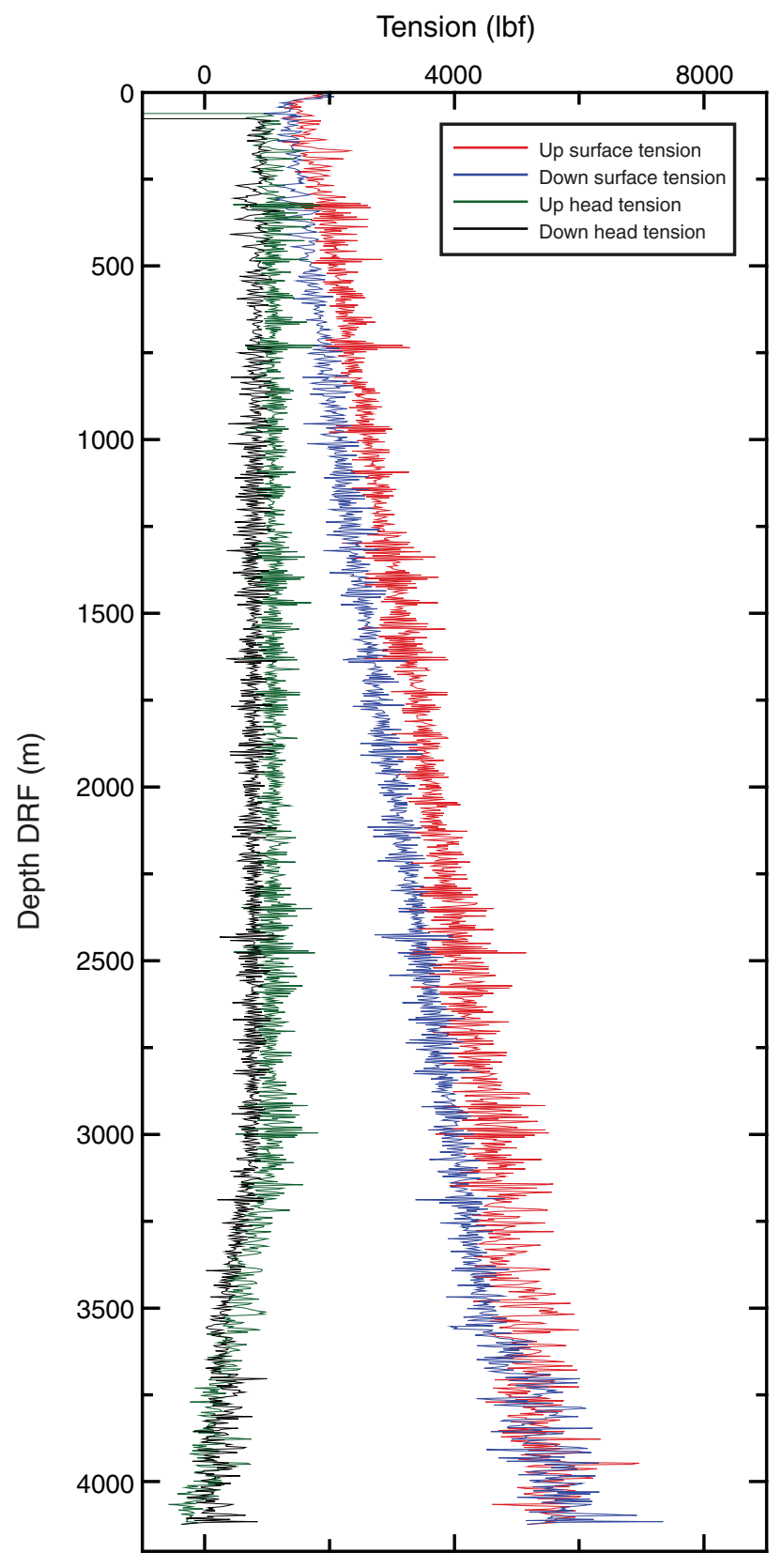


Figure F49. Total and spectral gamma ray measurements obtained inside the bottom-hole assembly in the upper $27 \mathrm{~m}$ of Hole U1350A. HSGR = gamma ray log, HCGR = computed gamma radiation, HTHO = thorium measurement, HURA = uranium measurement.

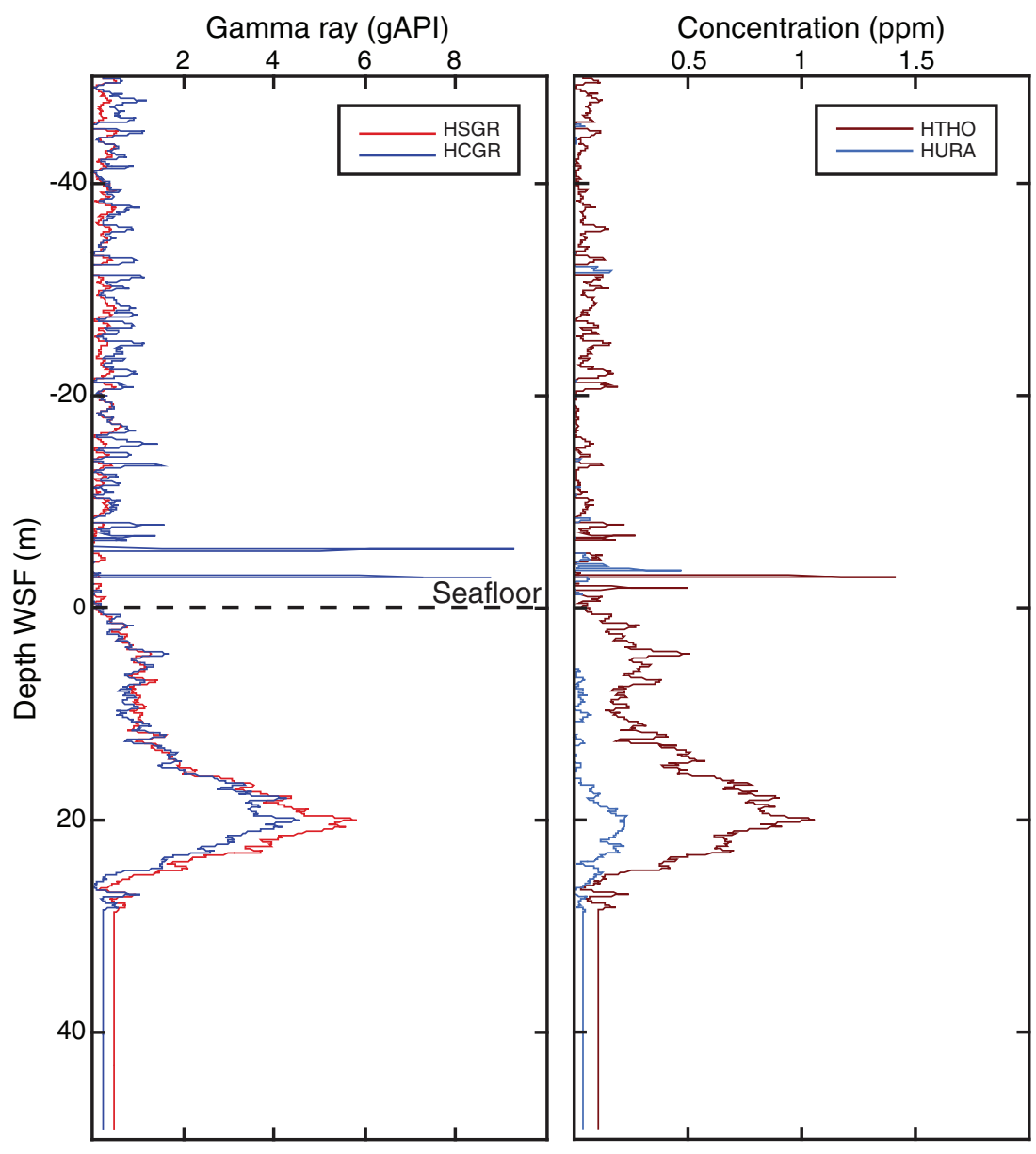


Table T1. Coring summary, Site U1350. (See table notes.)

\begin{tabular}{|c|c|c|c|c|c|}
\hline $\begin{array}{l}\text { Site U13 } \\
\text { Time } c\end{array}$ & \multicolumn{4}{|c|}{ Time on site (h): 179.5 (0115 h, 13 October-1245 h, 20 October 2009) } & \\
\hline \multicolumn{6}{|c|}{ Hole U1350A } \\
\hline \multicolumn{6}{|c|}{ Latitude: $36^{\circ} 04.491^{\prime} \mathrm{N}$} \\
\hline \multicolumn{6}{|c|}{ Longitude: $159^{\circ} 17.065^{\prime} \mathrm{E}$} \\
\hline \multicolumn{6}{|c|}{ Time on hole (h): 179.5 (0115 h, 13 October-1245 h, 20 October 2009) } \\
\hline \multicolumn{6}{|c|}{ Seafloor (drill pipe measured below rig floor, m DRF): 4067.0} \\
\hline \multicolumn{6}{|c|}{ Distance between rig floor and sea level $(\mathrm{m}): 11.1$} \\
\hline \multicolumn{6}{|c|}{ Water depth (drill pipe measured from sea level, mbsl): 4055.9} \\
\hline \multicolumn{6}{|c|}{ Total depth (drill pipe measured from rig floor, m DRF): 4382.8} \\
\hline \multicolumn{6}{|c|}{ Total penetration (drilling depth below seafloor, m DSF): 315.8} \\
\hline \multicolumn{6}{|c|}{ Total length of cored section $(\mathrm{m}): 211.2$ (172.7 in igneous basement) } \\
\hline \multicolumn{6}{|c|}{ Total core recovered $(\mathrm{m}): 75.19$} \\
\hline \multicolumn{6}{|c|}{ Core recovery (\%): 35.6 (43.2 igneous basement) } \\
\hline \multicolumn{6}{|c|}{ Total number of cores: 26} \\
\hline \multirow[b]{2}{*}{ Core } & \multicolumn{2}{|c|}{ Depth DSF $(m)$} & \multirow{2}{*}{$\begin{array}{l}\text { Interval } \\
\text { advanced } \\
(\mathrm{m})\end{array}$} & \multirow{2}{*}{$\begin{array}{l}\text { Length of core } \\
\text { recovered } \\
(\mathrm{m})\end{array}$} & \multirow[b]{2}{*}{$\begin{array}{c}\text { Recovery } \\
\text { (\%) }\end{array}$} \\
\hline & $\begin{array}{l}\text { Top of cored } \\
\text { interval }\end{array}$ & $\begin{array}{l}\text { Bottom of } \\
\text { cored interval }\end{array}$ & & & \\
\hline \multicolumn{6}{|c|}{ 324-U1350A- } \\
\hline $1 \mathrm{~W}$ & 0.0 & 104.6 & 104.6 & 0.10 & 0 \\
\hline $2 \mathrm{R}$ & 104.6 & 114.2 & 9.6 & 0.00 & 0 \\
\hline $3 R$ & 114.2 & 123.8 & 9.6 & 0.10 & 1 \\
\hline $4 \mathrm{R}$ & 123.8 & 133.4 & 9.6 & 0.25 & 3 \\
\hline $5 \mathrm{R}$ & 133.4 & 143.0 & 9.6 & 0.20 & 2 \\
\hline $6 \mathrm{R}$ & 143.0 & 152.6 & 9.6 & 0.22 & 2 \\
\hline $7 R$ & 152.6 & 155.3 & 2.7 & 1.44 & 53 \\
\hline $8 \mathrm{R}$ & 155.3 & 162.3 & 7.0 & 2.80 & 40 \\
\hline $9 \mathrm{R}$ & 162.3 & 171.9 & 9.6 & 6.30 & 66 \\
\hline $10 \mathrm{R}$ & 171.9 & 181.5 & 9.6 & 1.87 & 19 \\
\hline $11 R$ & 181.5 & 191.1 & 9.6 & 2.42 & 25 \\
\hline $12 \mathrm{R}$ & 191.1 & 195.9 & 4.8 & 0.62 & 13 \\
\hline $13 R$ & 195.9 & 200.7 & 4.8 & 1.86 & 39 \\
\hline $14 \mathrm{R}$ & 200.7 & 205.5 & 4.8 & 1.38 & 29 \\
\hline $15 R$ & 205.5 & 210.3 & 4.8 & 2.40 & 50 \\
\hline $16 \mathrm{R}$ & 210.3 & 219.9 & 9.6 & 2.71 & 28 \\
\hline $17 R$ & 219.9 & 229.5 & 9.6 & 3.34 & 35 \\
\hline $18 \mathrm{R}$ & 229.5 & 239.1 & 9.6 & 3.26 & 34 \\
\hline $19 R$ & 239.1 & 248.7 & 9.6 & 2.70 & 28 \\
\hline $20 \mathrm{R}$ & 248.7 & 258.3 & 9.6 & 2.75 & 29 \\
\hline $21 R$ & 258.3 & 267.8 & 9.5 & 3.30 & 35 \\
\hline $22 \mathrm{R}$ & 267.8 & 277.4 & 9.6 & 7.25 & 76 \\
\hline $23 R$ & 277.4 & 287.0 & 9.6 & 5.46 & 57 \\
\hline $24 R$ & 287.0 & 296.7 & 9.7 & 4.51 & 46 \\
\hline $25 \mathrm{R}$ & 296.7 & 306.2 & 9.5 & 9.12 & 96 \\
\hline \multirow[t]{3}{*}{$26 \mathrm{R}$} & 306.2 & 315.8 & 9.6 & 8.93 & 93 \\
\hline & & Totals: & 315.8 & 75.3 & 24 \\
\hline & \multicolumn{2}{|c|}{ Totals without wash barrel: } & 211.2 & 75.2 & 36 \\
\hline
\end{tabular}

Notes: $\mathrm{DRF}=$ drilling depth below rig floor, DSF $=$ drilling depth below seafloor. Local time $=$ UTC $+10 \mathrm{~h}$. 
Table T2. Calcareous nannofossil age assignments, Site U1350. (See table notes.)

\begin{tabular}{|c|c|c|c|}
\hline $\begin{array}{l}\text { Core, section, } \\
\text { interval }(\mathrm{cm})\end{array}$ & $\begin{array}{l}\text { Age-diagnostic species } \\
\text { (Abundance) }\end{array}$ & Stratigraphic range (Zone) & $\begin{array}{c}\text { Age (Ma) } \\
\text { (Range estimation) }\end{array}$ \\
\hline $\begin{array}{l}\text { 324-U1350A- } \\
1 \mathrm{~W}-1,5-6^{*}\end{array}$ & $\begin{array}{l}\text { Eprolithus floralis (R) } \\
\text { Staurolithites siesseri (F) } \\
\text { Zeugrhabdotus diplogramus (F) }\end{array}$ & $\begin{array}{l}\text { Albian-Santonian (CC8/NC8-CC15) } \\
\text { ?-Albian (?-NC8a-b) } \\
\text { Valanginian?-Santonian/Campanian boundary (?-UC12) }\end{array}$ & $112.6-107.3$ \\
\hline $1 \mathrm{~W}-1,9-10^{\dagger}$ & $\begin{array}{l}\text { Cretarhabdus striatus (R) } \\
\text { Cruciellipsis cuvillieri (R) } \\
\text { Haqins circumradiatus (R) } \\
\text { Staurolithites siesseri (F) }\end{array}$ & $\begin{array}{l}\text { Aptian-Cenomanian (?-UC4) } \\
\text { Tithonian-Hauterivian (NJ18-NC5) } \\
\text { Hauterivian-Campanian (?-UC15c) } \\
\text { ?-Albian (?-NC8a-b) }\end{array}$ & (Mixed Early Cretaceous) \\
\hline $3 R-1,5-6$ & $\begin{array}{l}\text { Cretarhabdus striatus (R) } \\
\text { Cruciellipsis cuvillieri (R) } \\
\text { Staurolithites siesseri (R) }\end{array}$ & $\begin{array}{l}\text { Aptian-Cenomanian (?-UC4) } \\
\text { Tithonian-Hauterivian (NJ18-NC5) } \\
\text { ?-Albian (?-NC8a-b) }\end{array}$ & (Mixed Early Cretaceous) \\
\hline $4 \mathrm{R}-1,18-19$ & $\begin{array}{l}\text { Cruciellipsis cuvillieri (F) } \\
\text { Rotelappilius crenulatus (R) } \\
\text { Speetonia sp. (R) }\end{array}$ & $\begin{array}{l}\text { Tithonian-Hauterivian (NJ18-NC5) } \\
\text { mid-Hauterivian-Maastrichtian (?NC4-CC26?) } \\
\text { Berriasian-Hauterivian (NK3-NC5) }\end{array}$ & $131.2-128.3$ \\
\hline $6 \mathrm{R}-1,10-11^{\ddagger}$ & Rhagodiscus asper (F) & Tithonian-Cenomanian (NJ18-UC5) & $>140-93$ \\
\hline 8R-1 (Piece 1, 2-4) & $\begin{array}{l}\text { Rhagodiscus asper (R) } \\
\text { Staurolithes crux }(\mathrm{R})\end{array}$ & $\begin{array}{l}\text { Tithonian-Cenomanian (NJ18-UC5) } \\
\text { Hauterivian-Maastrichtian }\end{array}$ & $131.5-93$ \\
\hline 9R-1 (Piece 2, 10-11) & $\begin{array}{l}\text { Axopodorhabdus albianus (R) } \\
\text { Cruciellipsis cuvillieri (F) } \\
\text { Rhagodiscus angustus (R) } \\
\text { Zeugrhabdotus erectus (R) }\end{array}$ & $\begin{array}{l}\text { Albian/Cenomanian-upper Cenomanian (NC9-UC5a) } \\
\text { Tithonian-Hauterivian (NJ18-NC5) } \\
\text { Aptian-Maastrichtian (NC8a-b-?) } \\
\text { lower Berriasian (NK1-NK2a)** }\end{array}$ & (Mixed Early Cretaceous) \\
\hline
\end{tabular}

Notes: ${ }^{*}=$ red chert, $\dagger=$ black chert, $\ddagger=$ limestone on chert. ${ }^{*}=$ ODP Leg 198 Hole 1213B. Abundance: $F=$ frequent, $R=$ rare. Zone ranges are only given for properly defined taxa. 
Table T3. Original microphenocryst and/or phenocryst abundances, Site U1350. (See table notes.)

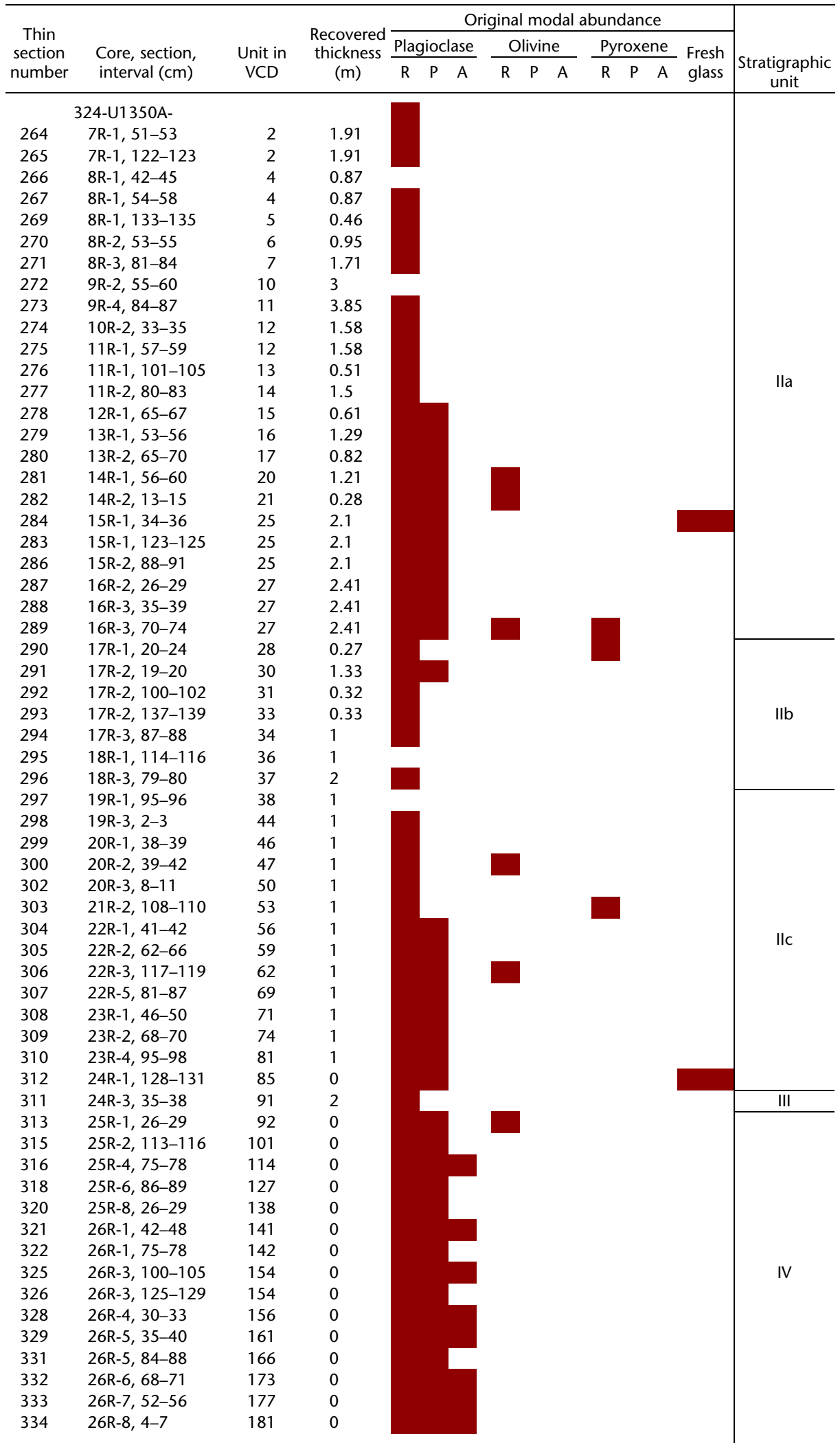

Notes: $\mathrm{VCD}=$ visual core description. $\mathrm{R}=$ rare $(<1 \%), \mathrm{P}=$ present $(1 \%-5 \%), \mathrm{A}=$ abundant $(>5 \%)$. 
Table T4. Whole-rock major and trace element compositions, Hole U1350A. (See table notes.) (Continued on next two pages.)

\begin{tabular}{|c|c|c|c|c|c|c|c|c|c|c|c|c|c|c|}
\hline \multirow[b]{2}{*}{ Stratigraphic unit: } & \multicolumn{14}{|c|}{ 324-U1350A- } \\
\hline & \multicolumn{14}{|c|}{ Ila } \\
\hline Core: & $7 R$ & $8 \mathrm{R}$ & $8 \mathrm{R}$ & $8 \mathrm{R}$ & $9 \mathrm{R}$ & $9 \mathrm{R}$ & $10 \mathrm{R}$ & $11 R$ & $11 R$ & $12 \mathrm{R}$ & $13 R$ & $13 R$ & $14 \mathrm{R}$ & $15 R$ \\
\hline Section: & 1 & 1 & 2 & 3 & 2 & 4 & 2 & 1 & 2 & 1 & 1 & 2 & 2 & 1 \\
\hline Piece: & 18 & $3 B$ & 9 & 10 & $1 \mathrm{E}$ & 3 & 6 & 6 & 7 & 7 & 3 & 6 & 2 & $12 B$ \\
\hline Interval $(\mathrm{cm})$ : & $122-123$ & $43-45$ & $51-55$ & $81-84$ & $57-58$ & $85-87$ & $33-35$ & $59-60$ & $80-81$ & $64-68$ & $54-56$ & $68-71$ & $13-16$ & $121-124$ \\
\hline Top depth (mbsf): & 153.82 & 155.72 & 157.28 & 158.88 & 163.92 & 166.58 & 173.68 & 182.09 & 183.82 & 191.74 & 196.44 & 198.01 & 202.00 & 206.71 \\
\hline \multicolumn{15}{|c|}{ Major element oxide (wt\%): } \\
\hline $\mathrm{SiO}_{2}$ & 50.93 & 50.65 & 49.46 & 50.91 & 53.04 & 51.04 & 49.73 & 49.30 & 49.17 & 50.10 & 49.46 & 49.74 & 51.14 & 51.87 \\
\hline $\mathrm{TiO}_{2}$ & 1.86 & 1.81 & 2.40 & 2.40 & 2.41 & 2.36 & 2.32 & 2.27 & 2.32 & 2.20 & 2.10 & 2.14 & 2.22 & 2.09 \\
\hline $\mathrm{A}_{12} \mathrm{O}_{3}$ & 16.02 & 15.82 & 14.63 & 15.00 & 15.42 & 15.19 & 14.73 & 14.48 & 15.00 & 16.08 & 15.40 & 15.77 & 16.53 & 15.85 \\
\hline $\mathrm{Fe}_{2} \mathrm{O}_{3}^{\top}$ & 11.59 & 12.64 & 14.08 & 11.01 & 12.25 & 13.29 & 14.29 & 14.09 & 11.74 & 13.55 & 13.52 & 13.63 & 12.66 & 10.19 \\
\hline $\mathrm{MnO}$ & 0.10 & 0.12 & 0.17 & 0.18 & 0.15 & 0.12 & 0.17 & 0.14 & 0.22 & 0.15 & 0.19 & 0.14 & 0.15 & 0.12 \\
\hline $\mathrm{MgO}$ & 6.64 & 6.58 & 7.39 & 6.15 & 6.11 & 6.12 & 7.21 & 7.31 & 5.73 & 7.12 & 6.67 & 7.33 & 5.94 & 6.79 \\
\hline $\mathrm{CaO}$ & 9.68 & 10.54 & 10.57 & 11.52 & 10.67 & 10.16 & 10.38 & 9.10 & 12.82 & 10.89 & 12.57 & 10.59 & 10.59 & 10.07 \\
\hline $\mathrm{Na}_{2} \mathrm{O}$ & 3.24 & 3.11 & 3.18 & 3.37 & 3.40 & 3.28 & 3.27 & 3.39 & 3.38 & 3.24 & 3.14 & 3.11 & 3.40 & 3.28 \\
\hline $\mathrm{K}_{2} \mathrm{O}$ & 0.16 & 0.10 & 0.21 & 0.61 & 0.59 & 0.49 & 0.25 & 0.21 & 0.44 & 0.21 & 0.09 & 0.15 & 0.20 & 0.17 \\
\hline $\mathrm{P}_{2} \mathrm{O}_{5}$ & 0.20 & 0.19 & 0.29 & 0.30 & 0.31 & 0.28 & 0.30 & 0.30 & 0.26 & 0.26 & 0.23 & 0.25 & 0.22 & 0.22 \\
\hline Totals: & 100.43 & 101.57 & 102.39 & 101.44 & 104.35 & 102.32 & 102.64 & 100.60 & 101.08 & 103.80 & 103.37 & 102.85 & 103.04 & 100.67 \\
\hline LOI & 1.17 & 1.10 & 1.33 & 2.96 & 0.73 & 0.02 & 0.44 & 1.11 & 4.40 & 1.93 & 2.02 & 2.66 & 2.48 & 1.28 \\
\hline \multicolumn{15}{|c|}{ Major element oxide (wt\%) normalized to 100 wt\%: } \\
\hline $\mathrm{SiO}_{2}$ & 50.71 & 49.87 & 48.31 & 50.19 & 50.99 & 49.88 & 48.45 & 49.01 & 48.64 & 48.59 & 48.28 & 48.37 & 49.63 & 51.52 \\
\hline $\mathrm{TiO}_{2}$ & 1.85 & 1.79 & 2.34 & 2.37 & 2.33 & 2.31 & 2.27 & 2.26 & 2.29 & 2.14 & 2.05 & 2.08 & 2.15 & 2.08 \\
\hline $\mathrm{Al}_{2} \mathrm{O}_{3}$ & 15.95 & 15.58 & 14.29 & 14.79 & 14.87 & 14.85 & 14.35 & 14.40 & 14.84 & 15.49 & 14.92 & 15.34 & 16.04 & 15.75 \\
\hline $\mathrm{Fe}_{2} \mathrm{O}_{3}^{\top}$ & 11.54 & 12.44 & 13.75 & 10.85 & 11.43 & 12.98 & 13.92 & 14.01 & 11.62 & 12.67 & 12.55 & 13.26 & 12.29 & 10.13 \\
\hline $\mathrm{MnO}$ & 0.10 & 0.12 & 0.16 & 0.18 & 0.14 & 0.11 & 0.16 & 0.14 & 0.22 & 0.14 & 0.18 & 0.14 & 0.14 & 0.12 \\
\hline $\mathrm{MgO}$ & 6.61 & 6.48 & 7.22 & 6.06 & 5.88 & 5.99 & 7.03 & 7.27 & 5.67 & 6.91 & 6.49 & 7.12 & 5.76 & 6.75 \\
\hline $\mathrm{CaO}$ & 9.64 & 10.37 & 10.32 & 11.35 & 10.28 & 9.93 & 10.11 & 9.04 & 12.68 & 10.52 & 12.21 & 10.30 & 10.27 & 10.01 \\
\hline $\mathrm{Na}_{2} \mathrm{O}$ & 3.23 & 3.06 & 3.10 & 3.32 & 3.23 & 3.20 & 3.19 & 3.37 & 3.35 & 3.11 & 3.03 & 3.02 & 3.30 & 3.26 \\
\hline $\mathrm{K}_{2} \mathrm{O}$ & 0.16 & 0.10 & 0.21 & 0.60 & 0.56 & 0.48 & 0.24 & 0.20 & 0.43 & 0.20 & 0.08 & 0.14 & 0.19 & 0.17 \\
\hline $\mathrm{P}_{2} \mathrm{O}_{5}$ & 0.20 & 0.19 & 0.29 & 0.29 & 0.29 & 0.27 & 0.29 & 0.30 & 0.26 & 0.23 & 0.20 & 0.24 & 0.21 & 0.22 \\
\hline Totals: & 100.00 & 100.00 & 100.00 & 100.00 & 100.00 & 100.00 & 100.00 & 100.00 & 100.00 & 100.00 & 100.00 & 100.00 & 100.00 & 100.00 \\
\hline Mg\# & 57.1 & 54.8 & 55.0 & 56.5 & 54.5 & 51.8 & 54.0 & 54.7 & 53.2 & 56.0 & 54.6 & 55.6 & 52.2 & 60.8 \\
\hline \multicolumn{15}{|l|}{ Trace element (ppm): } \\
\hline $\mathrm{Ba}$ & 23 & 21 & 63 & 734 & 103 & 89 & 50 & 49 & 103 & 19 & 56 & 16 & 29 & 28 \\
\hline $\mathrm{Sr}$ & 218 & 216 & 277 & 304 & 279 & 281 & 259 & 254 & 269 & 227 & 222 & 221 & 239 & 225 \\
\hline $\mathrm{Zr}$ & 110 & 105 & 167 & 169 & 175 & 155 & 154 & 163 & 143 & 131 & 128 & 126 & 132 & 131 \\
\hline Y & 27 & 24 & 40 & 34 & 32 & 29 & 34 & 38 & 32 & 35 & 32 & 33 & 31 & 26 \\
\hline V & 386 & 377 & 364 & 359 & 370 & 356 & 374 & 359 & 379 & 433 & 415 & 429 & 439 & 395 \\
\hline Sc & 52 & 52 & 43 & 43 & 44 & 43 & 46 & 44 & 47 & 52 & 50 & 51 & 52 & 49 \\
\hline $\mathrm{Cu}$ & 163 & 149 & 108 & 125 & 125 & 115 & 132 & 124 & 149 & 162 & 160 & 162 & 166 & 158 \\
\hline $\mathrm{Zn}$ & 108 & 99 & 118 & 98 & 99 & 99 & 117 & 108 & 106 & 110 & 113 & 105 & 112 & 99 \\
\hline Co & 52 & 86 & 74 & 81 & 89 & 75 & 64 & 52 & 76 & 54 & 92 & 86 & 61 & 64 \\
\hline $\mathrm{Cr}$ & 265 & 281 & 109 & 96 & 92 & 107 & 97 & 85 & 69 & 232 & 236 & 228 & 241 & 220 \\
\hline $\mathrm{Ni}$ & 52 & 62 & 51 & 51 & 55 & 55 & 42 & 38 & 42 & 59 & 74 & 68 & 84 & 68 \\
\hline
\end{tabular}

Notes: All analyses were conducted on samples ignited to $1025^{\circ} \mathrm{C}$. $\mathrm{Fe}_{2} \mathrm{O}_{3}{ }^{\top}=$ total iron expressed as $\mathrm{Fe}_{2} \mathrm{O}_{3}$. LOI $=$ weight loss on ignition. Mg\# $=$ $100 \times\left(\mathrm{Mg}^{2+} /\left(\mathrm{Mg}^{2+}+\mathrm{Fe}^{2+}\right]\right)$, assuming that $\mathrm{Fe}_{2} \mathrm{O}_{3} / \mathrm{FeO}=0.15 . \mathrm{BD}=$ below detection. 
Table T4 (continued). (Continued on next page.)

\begin{tabular}{|c|c|c|c|c|c|c|c|c|c|c|c|c|c|c|}
\hline \multirow{2}{*}{ Stratigraphic unit: } & \multicolumn{14}{|c|}{ 324-U1350A- } \\
\hline & \multirow{2}{*}{$\frac{\text { Ila }}{16 \mathrm{R}}$} & \multicolumn{7}{|c|}{$\mathrm{Ilb}$} & \multicolumn{6}{|c|}{ IIC } \\
\hline Core: & & $17 R$ & $17 R$ & $17 \mathrm{R}$ & $17 R$ & $17 R$ & $18 \mathrm{R}$ & $18 \mathrm{R}$ & $19 R$ & $19 R$ & $20 R$ & $20 R$ & $21 R$ & $22 \mathrm{R}$ \\
\hline Section: & 3 & 1 & 2 & 2 & 2 & 3 & 1 & 3 & 1 & 3 & 1 & 3 & 2 & 1 \\
\hline Piece: & $1 \mathrm{~B}$ & $3 \mathrm{~A}$ & $3 \mathrm{~A}$ & 13 & 18 & $8 B$ & 12 & 11 & $1 \mathrm{G}$ & 1 & 7 & 1 & 14 & 7 \\
\hline Interval $(\mathrm{cm})$ : & $38-40$ & $24-26$ & $16-19$ & $100-103$ & $133-136$ & $87-89$ & $114-115$ & 79-81 & $93-95$ & $3-5$ & $36-37$ & $9-11$ & $108-111$ & $41-43$ \\
\hline Top depth (mbsf): & 212.34 & 220.14 & 221.56 & 222.40 & 222.72 & 223.66 & 230.64 & 233.22 & 240.03 & 242.00 & 249.06 & 251.50 & 260.88 & 268.20 \\
\hline \multicolumn{15}{|c|}{ Major element oxide (wt\%): } \\
\hline $\mathrm{SiO}_{2}$ & 49.49 & 51.05 & 48.62 & 47.81 & 49.13 & 48.40 & 50.90 & 49.59 & 50.24 & 49.31 & 49.94 & 47.95 & 48.14 & 48.13 \\
\hline $\mathrm{TiO}_{2}$ & 1.39 & 2.54 & 1.71 & 2.09 & 2.18 & 2.17 & 2.14 & 2.10 & 2.04 & 2.11 & 2.15 & 2.01 & 1.82 & 2.06 \\
\hline $\mathrm{A}_{12} \mathrm{O}_{3}$ & 15.55 & 14.69 & 14.68 & 14.13 & 14.83 & 14.49 & 15.27 & 14.19 & 14.26 & 15.05 & 15.56 & 14.59 & 14.97 & 14.72 \\
\hline $\mathrm{Fe}_{2} \mathrm{O}_{3}^{\top}$ & 10.22 & 13.54 & 14.04 & 14.03 & 13.98 & 13.67 & 11.77 & 14.08 & 11.63 & 13.73 & 13.73 & 10.95 & 11.65 & 12.21 \\
\hline $\mathrm{MnO}$ & 0.15 & 0.13 & 0.14 & 0.21 & 0.18 & 0.18 & 0.14 & 0.24 & 0.14 & 0.13 & 0.14 & 0.11 & 0.11 & 0.13 \\
\hline $\mathrm{MgO}$ & 7.89 & 6.46 & 7.84 & 7.14 & 7.39 & 7.02 & 7.22 & 6.99 & 7.25 & 7.56 & 7.44 & 6.83 & 7.70 & 7.46 \\
\hline $\mathrm{CaO}$ & 13.37 & 8.24 & 9.78 & 10.96 & 10.54 & 11.56 & 10.19 & 12.29 & 10.65 & 9.89 & 10.58 & 9.39 & 10.04 & 9.45 \\
\hline $\mathrm{Na}_{2} \mathrm{O}$ & 2.07 & 3.54 & 2.90 & 3.02 & 3.13 & 2.93 & 3.27 & 2.82 & 3.04 & 3.11 & 3.17 & 3.07 & 2.91 & 3.13 \\
\hline $\mathrm{K}_{2} \mathrm{O}$ & 0.10 & 0.73 & 0.13 & 0.21 & 0.19 & 0.21 & 0.33 & 0.22 & 0.38 & 0.22 & 0.13 & 0.12 & 0.19 & 0.14 \\
\hline $\mathrm{P}_{2} \mathrm{O}_{5}$ & 0.18 & 0.31 & 0.24 & 0.25 & 0.28 & 0.25 & 0.24 & 0.26 & 0.22 & 0.26 & 0.26 & 0.18 & 0.21 & 0.24 \\
\hline Totals: & 100.41 & 101.24 & 100.10 & 99.85 & 101.82 & 100.89 & 101.47 & 102.78 & 99.84 & 101.37 & 103.11 & 95.20 & 97.73 & 97.67 \\
\hline LOI & 2.04 & 1.81 & 2.36 & 3.40 & 2.68 & 1.85 & 2.98 & 1.92 & 2.26 & 1.50 & 1.70 & 1.32 & 1.97 & 1.63 \\
\hline \multicolumn{15}{|c|}{ Major element oxide (wt\%) normalized to $100 \mathrm{wt} \%$ : } \\
\hline $\mathrm{SiO}_{2}$ & 49.29 & 50.42 & 48.58 & 47.88 & 48.25 & 47.97 & 50.16 & 48.25 & 50.32 & 48.64 & 48.43 & 50.37 & 49.25 & 49.28 \\
\hline $\mathrm{TiO}_{2}$ & 1.38 & 2.51 & 1.71 & 2.09 & 2.14 & 2.15 & 2.11 & 2.04 & 2.04 & 2.08 & 2.09 & 2.11 & 1.86 & 2.11 \\
\hline $\mathrm{Al}_{2} \mathrm{O}_{3}$ & 15.49 & 14.51 & 14.67 & 14.16 & 14.56 & 14.36 & 15.05 & 13.80 & 14.28 & 14.85 & 15.09 & 15.33 & 15.32 & 15.07 \\
\hline $\mathrm{Fe}_{2} \mathrm{O}_{3}^{\top}$ & 10.18 & 13.38 & 14.02 & 14.05 & 13.73 & 13.55 & 11.60 & 13.70 & 11.65 & 13.55 & 13.32 & 11.50 & 11.92 & 12.50 \\
\hline $\mathrm{MnO}$ & 0.15 & 0.13 & 0.14 & 0.21 & 0.18 & 0.18 & 0.13 & 0.23 & 0.15 & 0.13 & 0.14 & 0.12 & 0.11 & 0.14 \\
\hline $\mathrm{MgO}$ & 7.85 & 6.38 & 7.84 & 7.15 & 7.26 & 6.96 & 7.12 & 6.80 & 7.26 & 7.46 & 7.22 & 7.17 & 7.88 & 7.63 \\
\hline $\mathrm{CaO}$ & 13.32 & 8.14 & 9.77 & 10.97 & 10.35 & 11.46 & 10.05 & 11.96 & 10.67 & 9.76 & 10.26 & 9.86 & 10.27 & 9.68 \\
\hline $\mathrm{Na}_{2} \mathrm{O}$ & 2.07 & 3.50 & 2.90 & 3.02 & 3.07 & 2.91 & 3.22 & 2.75 & 3.04 & 3.07 & 3.08 & 3.22 & 2.98 & 3.21 \\
\hline $\mathrm{K}_{2} \mathrm{O}$ & 0.10 & 0.72 & 0.13 & 0.21 & 0.18 & 0.21 & 0.32 & 0.21 & 0.38 & 0.21 & 0.13 & 0.12 & 0.19 & 0.14 \\
\hline $\mathrm{P}_{2} \mathrm{O}_{5}$ & 0.18 & 0.31 & 0.24 & 0.25 & 0.27 & 0.25 & 0.23 & 0.25 & 0.22 & 0.25 & 0.25 & 0.19 & 0.21 & 0.24 \\
\hline Totals: & 100.00 & 100.00 & 100.00 & 100.00 & 100.00 & 100.00 & 100.00 & 100.00 & 100.00 & 100.00 & 100.00 & 100.00 & 100.00 & 100.00 \\
\hline $\mathrm{Mg} \#$ & 64.2 & 52.6 & 56.5 & 54.2 & 55.2 & 54.5 & 58.8 & 53.6 & 59.2 & 56.2 & 55.8 & 59.2 & 60.6 & 58.7 \\
\hline \multicolumn{15}{|l|}{ Trace element (ppm): } \\
\hline $\mathrm{Ba}$ & 40 & 958 & 22 & 46 & 181 & 50 & 84 & 47 & 73 & 73 & 36 & 37 & 33 & 56 \\
\hline $\mathrm{Sr}$ & 202 & 321 & 156 & 267 & 284 & 267 & 282 & 266 & 252 & 223 & 228 & 193 & 190 & 216 \\
\hline $\mathrm{Zr}$ & 89 & 192 & 108 & 143 & 149 & 150 & 139 & 144 & 135 & 123 & 126 & 118 & 100 & 133 \\
\hline$Y$ & 21 & 34 & 39 & 33 & 35 & 38 & 26 & 34 & 29 & 37 & 35 & 32 & 35 & 38 \\
\hline V & 259 & 379 & 406 & 338 & 351 & 350 & 361 & 339 & 336 & 414 & 422 & 391 & 380 & 371 \\
\hline Sc & 41 & 43 & 50 & 43 & 44 & 44 & 46 & 42 & 44 & 51 & 52 & 50 & 51 & 49 \\
\hline $\mathrm{Cu}$ & 115 & 98 & 114 & 125 & 127 & 125 & 143 & 126 & 125 & 174 & 179 & 164 & 178 & 118 \\
\hline $\mathrm{Zn}$ & 75 & 109 & 119 & 103 & 107 & 108 & 88 & 98 & 94 & 100 & 107 & 85 & 78 & 97 \\
\hline Co & 56 & 61 & 45 & 81 & 48 & 64 & 53 & 59 & 58 & 53 & 57 & 56 & 56 & 60 \\
\hline $\mathrm{Cr}$ & 299 & 62 & 135 & 130 & 136 & 126 & 132 & 140 & 117 & 171 & 179 & 159 & 182 & 77 \\
\hline $\mathrm{Ni}$ & 104 & 31 & 46 & 64 & 48 & 51 & 48 & 56 & 52 & 48 & 56 & 56 & 59 & 52 \\
\hline
\end{tabular}




\section{Table T4 (continued).}

\begin{tabular}{|c|c|c|c|c|c|c|c|c|c|c|c|c|c|c|c|}
\hline \multirow[b]{2}{*}{ Stratigraphic unit: } & \multicolumn{15}{|c|}{ 324-U1350A- } \\
\hline & \multicolumn{5}{|c|}{ IIC } & \multirow{2}{*}{$\begin{array}{c}\text { III } \\
24 R\end{array}$} & \multicolumn{9}{|c|}{ IV } \\
\hline Core: & $22 \mathrm{R}$ & $22 \mathrm{R}$ & $23 R$ & $23 R$ & $24 R$ & & $25 R$ & $25 R$ & $25 R$ & $25 R$ & $25 R$ & $26 \mathrm{R}$ & $26 \mathrm{R}$ & $26 R$ & $26 \mathrm{R}$ \\
\hline Section: & 3 & 5 & 2 & 4 & 1 & 3 & 1 & 2 & 4 & 6 & 8 & 1 & 4 & 6 & 8 \\
\hline Piece: & 1J & $1 \mathrm{D}$ & 4 & $3 \mathrm{~A}$ & $4 \mathrm{~B}$ & $2 \mathrm{~A}$ & 4 & $3 B$ & $6 \mathrm{~A}$ & 5 & $1 \mathrm{~B}$ & $6 B$ & $1 \mathrm{~A}$ & $6 \mathrm{~B}$ & 1 \\
\hline Interval (cm): & 117-119 & $84-85$ & 69-71 & 97-99 & $127-130$ & $38-40$ & $26-30$ & $116-119$ & $78-81$ & $83-88$ & $26-28$ & $75-78$ & $31-33$ & $68-71$ & $4-7$ \\
\hline Top depth (mbsf): & 271.34 & 273.82 & 279.51 & 282.64 & 288.27 & 290.25 & 296.96 & 299.36 & 301.82 & 304.48 & 306.42 & 306.95 & 310.58 & 313.67 & 315.33 \\
\hline \multicolumn{16}{|c|}{ Major element oxide (wt\%): } \\
\hline $\mathrm{SiO}_{2}$ & 48.07 & 47.54 & 47.58 & 47.71 & 46.89 & 47.39 & 47.92 & 47.37 & 47.76 & 48.28 & 48.92 & 48.51 & 47.96 & 48.19 & 47.34 \\
\hline $\mathrm{TiO}_{2}$ & 1.50 & 1.49 & 1.54 & 1.47 & 1.55 & 1.60 & 1.29 & 1.34 & 1.32 & 1.28 & 1.44 & 1.36 & 1.36 & 1.29 & 1.36 \\
\hline $\mathrm{A}_{12} \mathrm{O}_{3}$ & 16.67 & 16.08 & 17.00 & 16.07 & 17.02 & 17.21 & 17.02 & 16.48 & 17.13 & 18.02 & 16.70 & 16.40 & 16.87 & 15.77 & 16.12 \\
\hline $\mathrm{Fe}_{2} \mathrm{O}_{3}^{\top}$ & 10.51 & 10.71 & 9.98 & 10.52 & 10.84 & 10.45 & 9.56 & 9.85 & 9.71 & 8.96 & 10.66 & 10.58 & 9.34 & 10.09 & 9.55 \\
\hline $\mathrm{MnO}$ & 0.14 & 0.14 & 0.13 & 0.15 & 0.15 & 0.16 & 0.16 & 0.15 & 0.16 & 0.13 & 0.17 & 0.16 & 0.17 & 0.18 & 0.19 \\
\hline $\mathrm{MgO}$ & 6.06 & 6.28 & 5.75 & 6.95 & 4.86 & 5.05 & 7.36 & 7.55 & 7.69 & 7.16 & 8.77 & 9.32 & 7.80 & 9.44 & 7.97 \\
\hline $\mathrm{CaO}$ & 13.04 & 12.85 & 12.04 & 12.19 & 13.83 & 12.75 & 11.02 & 10.50 & 10.48 & 10.91 & 7.18 & 5.33 & 10.20 & 7.84 & 9.45 \\
\hline $\mathrm{Na}_{2} \mathrm{O}$ & 2.41 & 2.39 & 2.60 & 2.43 & 2.55 & 2.65 & 2.61 & 2.67 & 2.72 & 2.67 & 2.82 & 2.63 & 2.74 & 2.56 & 2.55 \\
\hline $\mathrm{K}_{2} \mathrm{O}$ & $\mathrm{BD}$ & $\mathrm{BD}$ & $\mathrm{BD}$ & $\mathrm{BD}$ & 0.06 & 0.02 & 0.16 & 0.08 & 0.10 & 0.16 & 1.62 & 3.00 & 0.52 & 1.92 & 1.46 \\
\hline $\mathrm{P}_{2} \mathrm{O}_{5}$ & 0.11 & 0.11 & 0.13 & 0.10 & 0.11 & 0.16 & 0.14 & 0.15 & 0.14 & 0.08 & 0.18 & 0.15 & 0.13 & 0.15 & 0.15 \\
\hline Totals: & 98.52 & 97.60 & 96.73 & 97.59 & 97.86 & 97.45 & 97.25 & 96.15 & 97.21 & 97.65 & 98.45 & 97.44 & 97.10 & 97.43 & 96.14 \\
\hline LOI & 1.25 & 1.93 & 2.02 & 1.33 & 1.72 & 1.72 & 2.10 & 1.41 & 2.18 & 4.04 & 3.24 & 3.89 & 2.37 & 3.31 & 3.45 \\
\hline \multicolumn{16}{|c|}{ Major element oxide (wt\%) normalized to $100 \mathrm{wt} \%$ : } \\
\hline $\mathrm{SiO}_{2}$ & 48.80 & 48.71 & 49.19 & 48.89 & 47.91 & 48.63 & 49.28 & 49.27 & 49.13 & 49.44 & 49.69 & 49.79 & 49.39 & 49.46 & 49.24 \\
\hline $\mathrm{TiO}_{2}$ & 1.52 & 1.53 & 1.59 & 1.50 & 1.59 & 1.65 & 1.33 & 1.40 & 1.35 & 1.31 & 1.46 & 1.39 & 1.40 & 1.32 & 1.41 \\
\hline $\mathrm{Al}_{2} \mathrm{O}_{3}$ & 16.93 & 16.48 & 17.57 & 16.47 & 17.39 & 17.66 & 17.51 & 17.14 & 17.63 & 18.46 & 16.97 & 16.83 & 17.38 & 16.19 & 16.77 \\
\hline $\mathrm{Fe}_{2} \mathrm{O}_{3}^{\top}$ & 10.66 & 10.97 & 10.31 & 10.78 & 11.08 & 10.72 & 9.83 & 10.25 & 9.99 & 9.17 & 10.83 & 10.86 & 9.62 & 10.36 & 9.94 \\
\hline $\mathrm{MnO}$ & 0.14 & 0.15 & 0.13 & 0.15 & 0.16 & 0.16 & 0.16 & 0.15 & 0.16 & 0.14 & 0.18 & 0.16 & 0.18 & 0.18 & 0.20 \\
\hline $\mathrm{MgO}$ & 6.16 & 6.44 & 5.95 & 7.13 & 4.97 & 5.19 & 7.56 & 7.85 & 7.91 & 7.33 & 8.91 & 9.56 & 8.04 & 9.69 & 8.28 \\
\hline $\mathrm{CaO}$ & 13.24 & 13.17 & 12.45 & 12.49 & 14.13 & 13.08 & 11.33 & 10.93 & 10.78 & 11.17 & 7.29 & 5.48 & 10.50 & 8.05 & 9.83 \\
\hline $\mathrm{Na}_{2} \mathrm{O}$ & 2.45 & 2.45 & 2.68 & 2.49 & 2.60 & 2.72 & 2.69 & 2.78 & 2.80 & 2.74 & 2.86 & 2.70 & 2.82 & 2.63 & 2.65 \\
\hline $\mathrm{K}_{2} \mathrm{O}$ & $\mathrm{BD}$ & $\mathrm{BD}$ & $B D$ & $\mathrm{BD}$ & 0.07 & 0.02 & 0.16 & 0.08 & 0.10 & 0.16 & 1.64 & 3.08 & 0.54 & 1.97 & 1.52 \\
\hline $\mathrm{P}_{2} \mathrm{O}_{5}$ & 0.11 & 0.11 & 0.13 & 0.10 & 0.11 & 0.16 & 0.15 & 0.16 & 0.14 & 0.09 & 0.18 & 0.15 & 0.13 & 0.15 & 0.16 \\
\hline Totals: & 100.00 & 100.00 & 100.00 & 100.00 & 100.00 & 100.00 & 100.00 & 100.00 & 100.00 & 100.00 & 100.00 & 100.00 & 100.00 & 100.00 & 100.00 \\
\hline Mg\# & 57.3 & 57.7 & 57.3 & 60.6 & 51.1 & 53.0 & 64.2 & 64.1 & 64.8 & 65.0 & 65.7 & 67.2 & 66.0 & 68.5 & 66.0 \\
\hline \multicolumn{16}{|l|}{ Trace element $(\mathrm{ppm})$ : } \\
\hline $\mathrm{Ba}$ & 27 & 31 & 32 & 30 & 27 & 35 & 39 & 38 & 43 & 41 & 66 & 85 & 51 & 57 & 58 \\
\hline $\mathrm{Sr}$ & 199 & 196 & 207 & 191 & 202 & 210 & 174 & 172 & 176 & 187 & 169 & 157 & 177 & 155 & 168 \\
\hline $\mathrm{Zr}$ & 84 & 84 & 86 & 83 & 88 & 87 & 67 & 67 & 67 & 64 & 70 & 65 & 67 & 63 & 63 \\
\hline Y & 24 & 24 & 23 & 22 & 27 & 27 & 26 & 31 & 25 & 13 & 29 & 27 & 20 & 23 & 16 \\
\hline V & 296 & 296 & 303 & 290 & 311 & 316 & 284 & 290 & 283 & 281 & 310 & 278 & 298 & 279 & 294 \\
\hline Sc & 40 & 40 & 41 & 39 & 42 & 44 & 42 & 45 & 43 & 45 & 47 & 43 & 46 & 40 & 43 \\
\hline $\mathrm{Cu}$ & 149 & 144 & 154 & 148 & 156 & 161 & 143 & 156 & 147 & 153 & 158 & 140 & 154 & 137 & 148 \\
\hline $\mathrm{Zn}$ & 80 & 85 & 81 & 88 & 91 & 100 & 94 & 99 & 89 & 65 & 105 & 126 & 72 & 73 & 76 \\
\hline Co & 56 & 61 & 60 & 57 & 57 & 67 & 53 & 49 & 50 & 46 & 45 & 52 & 47 & 39 & 53 \\
\hline $\mathrm{Cr}$ & 265 & 272 & 261 & 261 & 272 & 280 & 217 & 227 & 211 & 208 & 240 & 221 & 217 & 193 & 205 \\
\hline $\mathrm{Ni}$ & 124 & 143 & 125 & 108 & 124 & 126 & 84 & 79 & 72 & 76 & 76 & 88 & 75 & 79 & 77 \\
\hline
\end{tabular}


Table T5. Moisture and density measurements, Site U1350. (See table note.)

\begin{tabular}{|c|c|c|c|c|c|c|c|}
\hline \multirow{2}{*}{$\begin{array}{l}\text { Core, section, } \\
\text { interval }(\mathrm{cm})\end{array}$} & \multirow{2}{*}{$\begin{array}{l}\text { Top depth } \\
\text { (mbsf) }\end{array}$} & \multicolumn{3}{|c|}{ Density $\left(\mathrm{g} / \mathrm{cm}^{3}\right)$} & \multirow[b]{2}{*}{ Void ratio } & \multirow{2}{*}{$\begin{array}{c}\text { Water } \\
\text { content (\%) }\end{array}$} & \multirow[b]{2}{*}{ Porosity (\%) } \\
\hline & & Bulk & Dry & Grain & & & \\
\hline \multicolumn{8}{|l|}{ 324-U1350A- } \\
\hline $7 R-1,53-55$ & 153.13 & 2.681 & 2.562 & 2.899 & 0.132 & 4.441 & 11.627 \\
\hline $8 R-1,18-20$ & 155.48 & 2.712 & 2.630 & 2.861 & 0.088 & 3.050 & 8.078 \\
\hline $8 R-3,85-87$ & 158.92 & 2.522 & 2.296 & 2.947 & 0.284 & 8.968 & 22.089 \\
\hline $9 R-2,69-71$ & 164.04 & 2.551 & 2.324 & 2.988 & 0.286 & 8.924 & 22.233 \\
\hline 9R-4, 89-91 & 166.62 & 2.625 & 2.448 & 2.959 & 0.208 & 6.729 & 17.250 \\
\hline $9 R-6,4-6$ & 168.33 & 2.548 & 2.346 & 2.923 & 0.246 & 7.941 & 19.758 \\
\hline $11 \mathrm{R}-1,51-53$ & 182.01 & 2.534 & 2.306 & 2.966 & 0.286 & 8.994 & 22.257 \\
\hline 11R-2, 77-79 & 183.79 & 2.590 & 2.417 & 2.909 & 0.203 & 6.682 & 16.901 \\
\hline $12 \mathrm{R}-1,50-52$ & 191.60 & 2.585 & 2.398 & 2.933 & 0.223 & 7.221 & 18.229 \\
\hline $13 R-1,50-52$ & 196.40 & 2.649 & 2.497 & 2.932 & 0.174 & 5.738 & 14.842 \\
\hline $14 \mathrm{R}-1,78-80$ & 201.48 & 2.565 & 2.387 & 2.887 & 0.209 & 6.910 & 17.307 \\
\hline 14R-2, 9-11 & 201.96 & 2.565 & 2.376 & 2.914 & 0.226 & 7.368 & 18.455 \\
\hline $15 \mathrm{R}-1,126-128$ & 206.76 & 2.527 & 2.316 & 2.916 & 0.259 & 8.332 & 20.561 \\
\hline $16 \mathrm{R}-1,35-37$ & 210.65 & 2.405 & 2.114 & 2.955 & 0.398 & 12.109 & 28.445 \\
\hline $16 \mathrm{R}-2,72-74$ & 211.76 & 2.849 & 2.792 & 2.957 & 0.059 & 2.011 & 5.596 \\
\hline $17 R-2,34-36$ & 221.74 & 2.542 & 2.325 & 2.951 & 0.269 & 8.549 & 21.222 \\
\hline $17 R-3,72-74$ & 223.52 & 2.641 & 2.473 & 2.960 & 0.197 & 6.376 & 16.447 \\
\hline 18R-1, 97-99 & 230.47 & 2.608 & 2.416 & 2.973 & 0.231 & 7.355 & 18.733 \\
\hline $18 R-2,50-52$ & 231.44 & 2.669 & 2.550 & 2.886 & 0.132 & 4.464 & 11.636 \\
\hline $18 R-3,60-62$ & 233.04 & 2.733 & 2.617 & 2.952 & 0.128 & 4.243 & 11.326 \\
\hline 19R-1, 68-70 & 239.78 & 2.632 & 2.487 & 2.897 & 0.165 & 5.505 & 14.148 \\
\hline 20R-1, 31-33 & 249.01 & 2.648 & 2.490 & 2.946 & 0.183 & 5.992 & 15.496 \\
\hline $20 \mathrm{R}-3,4-6$ & 251.44 & 2.560 & 2.357 & 2.938 & 0.246 & 7.903 & 19.756 \\
\hline $21 \mathrm{R}-1,35-37$ & 258.65 & 2.596 & 2.406 & 2.952 & 0.227 & 7.291 & 18.483 \\
\hline $21 R-2,67-69$ & 260.47 & 2.585 & 2.386 & 2.961 & 0.241 & 7.698 & 19.433 \\
\hline $21 \mathrm{R}-3,48-50$ & 261.71 & 2.543 & 2.342 & 2.913 & 0.244 & 7.889 & 19.591 \\
\hline 22R-2, 97-99 & 269.84 & 2.827 & 2.791 & 2.891 & 0.035 & 1.242 & 3.427 \\
\hline $22 \mathrm{R}-3,113-115$ & 271.30 & 2.667 & 2.588 & 2.803 & 0.083 & 2.949 & 7.680 \\
\hline $22 R-5,67-69$ & 273.65 & 2.703 & 2.631 & 2.831 & 0.076 & 2.679 & 7.070 \\
\hline $23 \mathrm{R}-1,78-80$ & 278.18 & 2.628 & 2.472 & 2.918 & 0.181 & 5.964 & 15.308 \\
\hline $23 \mathrm{R}-2,49-51$ & 279.31 & 2.590 & 2.407 & 2.932 & 0.218 & 7.079 & 17.909 \\
\hline $23 R-4,92-94$ & 282.60 & 2.648 & 2.521 & 2.876 & 0.141 & 4.770 & 12.334 \\
\hline 24R-1, 109-111 & 288.11 & 2.581 & 2.406 & 2.901 & 0.206 & 6.768 & 17.061 \\
\hline $24 R-3,31-33$ & 290.20 & 2.650 & 2.508 & 2.911 & 0.161 & 5.349 & 13.843 \\
\hline $25 \mathrm{R}-1,24-26$ & 296.96 & 2.653 & 2.518 & 2.900 & 0.152 & 5.080 & 13.162 \\
\hline $25 \mathrm{R}-2,119-121$ & 299.41 & 2.652 & 2.525 & 2.882 & 0.141 & 4.783 & 12.386 \\
\hline 25R-4, 71-73 & 301.77 & 2.591 & 2.439 & 2.863 & 0.174 & 5.852 & 14.806 \\
\hline $25 R-5,57-59$ & 302.90 & 2.599 & 2.446 & 2.876 & 0.176 & 5.892 & 14.955 \\
\hline 25R-7, 13-15 & 304.94 & 2.560 & 2.405 & 2.836 & 0.179 & 6.082 & 15.208 \\
\hline $26 \mathrm{R}-1,78-80$ & 307.00 & 2.389 & 2.162 & 2.778 & 0.285 & 9.497 & 22.159 \\
\hline $26 \mathrm{R}-4,27-29$ & 310.56 & 2.583 & 2.436 & 2.845 & 0.168 & 5.697 & 14.371 \\
\hline $26 R-5,93-95$ & 312.48 & 2.556 & 2.467 & 2.700 & 0.094 & 3.454 & 8.621 \\
\hline 26R-8, 11-13 & 315.42 & 2.608 & 2.479 & 2.838 & 0.145 & 4.968 & 12.654 \\
\hline
\end{tabular}

Note: Water content is relative to wet mass. 
Table T6. Compressional wave velocity measurements, Site U1350. (See table notes.)

\begin{tabular}{|c|c|c|c|c|}
\hline \multirow{2}{*}{$\begin{array}{l}\text { Core, section, } \\
\text { interval }(\mathrm{cm})\end{array}$} & \multirow{2}{*}{$\begin{array}{l}\text { Top depth } \\
\text { (mbsf) }\end{array}$} & \multicolumn{3}{|c|}{ Velocity $(\mathrm{km} / \mathrm{s})$} \\
\hline & & $x$-direction & $y$-direction & $z$-direction \\
\hline \multicolumn{5}{|l|}{ 324-U1350A- } \\
\hline 7R-1, 53-55 & 153.13 & 5.142 & 5.102 & 5.222 \\
\hline $8 R-1,18-20$ & 155.48 & 5.682 & 5.700 & 5.700 \\
\hline $8 R-3,85-87$ & 158.92 & 4.123 & 4.187 & 4.226 \\
\hline 9R-2, 69-71 & 164.04 & 4.124 & 4.110 & 4.117 \\
\hline 9R-4, 89-91 & 166.62 & 4.711 & 4.691 & 4.734 \\
\hline $9 R-6,4-6$ & 168.33 & 4.275 & 4.208 & 4.287 \\
\hline $11 \mathrm{R}-1,51-53$ & 182.01 & 3.854 & 3.853 & 3.810 \\
\hline 11R-2, 77-79 & 183.79 & 4.429 & 4.448 & 4.513 \\
\hline $12 \mathrm{R}-1,50-52$ & 191.60 & $N A^{*}$ & $N A^{*}$ & $3.848^{*}$ \\
\hline $13 \mathrm{R}-1,50-52$ & 196.40 & 4.697 & 4.659 & 4.736 \\
\hline $14 \mathrm{R}-1,78-80$ & 201.48 & 4.314 & 4.357 & 4.370 \\
\hline 14R-2, 9-11 & 201.96 & 4.366 & 4.393 & 4.398 \\
\hline $15 R-1,126-128$ & 206.76 & 4.155 & 4.129 & 4.149 \\
\hline $16 \mathrm{R}-1,35-37$ & 210.65 & 3.929 & 4.060 & 4.052 \\
\hline $16 \mathrm{R}-2,72-74$ & 211.74 & 6.085 & 6.179 & 5.989 \\
\hline $17 \mathrm{R}-2,34-36$ & 221.74 & 3.860 & 4.065 & 4.020 \\
\hline $17 \mathrm{R}-3,72-74$ & 223.52 & 4.637 & 4.656 & 4.702 \\
\hline 18R-1, 97-99 & 230.47 & 4.296 & 4.408 & 4.368 \\
\hline $18 \mathrm{R}-2,50-52$ & 231.44 & 4.988 & 4.991 & 4.952 \\
\hline $18 \mathrm{R}-3,60-62$ & 233.04 & 5.419 & 5.356 & 5.335 \\
\hline 19R-1, 68-70 & 239.78 & 4.954 & 4.924 & 4.962 \\
\hline 20R-1, 31-33 & 249.01 & 4.612 & 4.557 & 4.629 \\
\hline $20 \mathrm{R}-3,4-6$ & 251.44 & 4.159 & 4.156 & 4.126 \\
\hline $21 \mathrm{R}-1,35-37$ & 258.65 & 4.408 & 4.433 & 4.364 \\
\hline $21 \mathrm{R}-2,67-69$ & 260.47 & 4.328 & 4.343 & 4.329 \\
\hline $21 \mathrm{R}-3,48-50$ & 261.71 & 4.136 & 4.132 & 4.136 \\
\hline 22R-2, 97-99 & 269.84 & 6.619 & 6.691 & 6.545 \\
\hline $22 \mathrm{R}-3,113-115$ & 271.30 & 5.978 & 5.901 & 5.924 \\
\hline $22 \mathrm{R}-5,67-69$ & 273.65 & 5.941 & 5.941 & 5.978 \\
\hline $23 \mathrm{R}-1,78-80$ & 278.18 & 4.848 & 4.870 & 4.718 \\
\hline $23 R-2,49-51$ & 279.31 & 4.562 & 4.534 & 4.552 \\
\hline 23R-4, 92-94 & 282.60 & 5.300 & 5.296 & 5.230 \\
\hline 24R-1, 109-111 & 288.09 & 4.800 & 4.714 & 4.799 \\
\hline $24 \mathrm{R}-3,31-33$ & 290.19 & 5.121 & 5.086 & 5.191 \\
\hline $25 R-1,24-26$ & 296.94 & 5.022 & 4.996 & 5.010 \\
\hline $25 \mathrm{R}-2,119-121$ & 299.39 & 5.095 & 5.124 & 5.167 \\
\hline $25 R-4,71-73$ & 301.75 & 4.863 & 4.777 & 4.795 \\
\hline $25 R-5,57-59$ & 302.89 & 4.811 & 4.777 & 4.707 \\
\hline 25R-7, 13-15 & 304.92 & 4.862 & 4.828 & 4.812 \\
\hline 26R-1, 78-80 & 306.98 & 3.880 & 3.882 & 4.010 \\
\hline $26 \mathrm{R}-4,27-29$ & 310.54 & 4.928 & 4.901 & 4.939 \\
\hline 26R-5, 93-95 & 312.46 & 5.641 & 5.524 & 5.585 \\
\hline $26 \mathrm{R}-8,11-13$ & 315.40 & 5.084 & 5.086 & 5.123 \\
\hline
\end{tabular}

Notes: * = sample was cracked and only $z$-direction was attainable; data should be treated with caution and is omitted from figures. NA $=$ not available. Values are accurate to $\pm 20 \mathrm{~m} / \mathrm{s}$. 
Table T7. Demagnetization results, Site U1350. (See table notes.)

\begin{tabular}{|c|c|c|c|c|c|c|c|c|c|c|c|}
\hline \multirow{2}{*}{$\begin{array}{l}\text { Core, section, } \\
\text { interval }(\mathrm{cm})\end{array}$} & \multicolumn{2}{|c|}{ Depth (mbsf) } & \multirow[b]{2}{*}{ Demagnetization } & \multicolumn{2}{|c|}{ Fit } & \multirow[b]{2}{*}{ N } & \multirow{2}{*}{$\begin{array}{c}\text { Inclination } \\
\left({ }^{\circ}\right)\end{array}$} & \multirow{2}{*}{$\begin{array}{l}\text { Declination } \\
\left({ }^{\circ}\right)\end{array}$} & \multirow{2}{*}{$\begin{array}{c}\text { MAD } \\
\left({ }^{\circ}\right)\end{array}$} & \multirow{2}{*}{$\underset{(\mathrm{SI})}{\mathrm{NRM} \chi}$} & \multirow{2}{*}{$\begin{array}{l}\mathrm{MDI} \\
(\mathrm{mT}\end{array}$} \\
\hline & Top & Bottom & & ${ }^{\circ} \mathrm{C}$ & $\mathrm{mT}$ & & & & & & \\
\hline \multicolumn{12}{|l|}{ 324-U1350A- } \\
\hline $7 \mathrm{R}-1,53-55$ & 153.13 & 153.15 & $\mathrm{TH}$ & $150-550$ & & 14 & -9.5 & -92.4 & 2.6 & $4.29 \mathrm{E}-02$ & \\
\hline $8 \mathrm{R}-1,18-20$ & 155.48 & 155.50 & $\mathrm{TH}$ & $325-550$ & & 10 & -30.9 & 78.6 & 9.9 & $4.50 \mathrm{E}-02$ & \\
\hline $8 R-3,85-87$ & 158.92 & 158.94 & $\mathrm{AF}$ & & $7-100$ & 12 & -1.3 & 13.4 & 1.6 & $3.72 \mathrm{E}-02$ & 7.9 \\
\hline $9 R-2,69-71$ & 164.04 & 164.06 & $\mathrm{TH}$ & $150-550$ & & 14 & 10.0 & -112.6 & 6.3 & $3.49 \mathrm{E}-02$ & \\
\hline $9 R-4,89-91$ & 166.62 & 166.64 & AF & & $10-100$ & 11 & -2.8 & 151.2 & 0.9 & $3.55 \mathrm{E}-02$ & 5.5 \\
\hline $9 R-6,4-6$ & 168.33 & 168.35 & $\mathrm{TH}$ & $100-500$ & & 13 & 31.2 & -156.5 & 9.3 & $2.33 \mathrm{E}-02$ & \\
\hline $11 \mathrm{R}-1,51-53$ & 182.01 & 182.03 & AF & & $10-80$ & 10 & 0.5 & -132.7 & 0.6 & 3.07E-02 & 8.4 \\
\hline $11 \mathrm{R}-2,77-79$ & 183.79 & 183.81 & $\mathrm{TH}$ & $150-550$ & & 14 & 7.6 & -126.6 & 6.2 & $3.21 \mathrm{E}-02$ & \\
\hline $12 \mathrm{R}-1,50-52$ & 191.60 & 191.62 & $\mathrm{AF}$ & & $10-80$ & 11 & 27.0 & 39.1 & 1.1 & $4.13 \mathrm{E}-02$ & 4.5 \\
\hline $13 R-1,50-52$ & 196.40 & 196.42 & TH & $150-550$ & & 14 & 43.0 & 113.7 & 4.9 & $4.39 \mathrm{E}-02$ & \\
\hline $14 \mathrm{R}-1,78-80$ & 201.48 & 201.50 & $\mathrm{TH}$ & $300-550$ & & 9 & 27.3 & -54.4 & 9.5 & $2.90 \mathrm{E}-02$ & \\
\hline 14R-2, 9-11 & 201.96 & 201.98 & $\mathrm{AF}$ & & $10-80$ & 10 & -1.0 & -33.0 & 1.3 & $4.71 \mathrm{E}-02$ & 4.8 \\
\hline $15 R-1,126-128$ & 206.76 & 206.78 & $\mathrm{TH}$ & $150-475$ & & 11 & 50.3 & 139.1 & 21.3 & $3.15 \mathrm{E}-02$ & \\
\hline 16R-1, 35-37 & 210.65 & 210.67 & $\mathrm{TH}$ & $300-575$ & & 12 & -2.3 & 50.8 & 2.0 & $2.05 \mathrm{E}-02$ & \\
\hline $16 \mathrm{R}-2,72-74$ & 211.74 & 211.76 & $\mathrm{AF}$ & & $15-100$ & 10 & -3.5 & 83.3 & 1.8 & $2.86 \mathrm{E}-02$ & 3.0 \\
\hline $17 R-2,34-36$ & 221.74 & 221.76 & $\mathrm{TH}$ & $150-575$ & & 15 & 18.3 & -58.3 & 3.3 & $3.30 \mathrm{E}-02$ & \\
\hline $17 \mathrm{R}-3,72-74$ & 223.52 & 223.54 & AF & & $10-80$ & 11 & 3.0 & 74.1 & 0.7 & $3.42 \mathrm{E}-02$ & 7.0 \\
\hline $18 \mathrm{R}-1,97-99$ & 230.47 & 230.49 & $\mathrm{TH}$ & $150-575$ & & 51 & 14.8 & -126.3 & 3.4 & $3.44 \mathrm{E}-02$ & \\
\hline $18 \mathrm{R}-2,50-52$ & 231.44 & 231.46 & AF & & $7-60$ & 11 & 14.5 & -176.1 & 0.9 & $5.16 \mathrm{E}-02$ & 5.0 \\
\hline $18 \mathrm{R}-3,60-62$ & 233.04 & 233.06 & $\mathrm{TH}$ & $200-575$ & & 14 & 29.0 & -136.1 & 1.9 & $3.52 \mathrm{E}-02$ & \\
\hline 19R-1, 68-70 & 239.78 & 239.80 & $\mathrm{AF}$ & & $10-60$ & 10 & 6.3 & -80.0 & 0.7 & $4.11 \mathrm{E}-02$ & 5.7 \\
\hline $20 \mathrm{R}-1,31-33$ & 249.01 & 249.03 & $\mathrm{TH}$ & $350-575$ & & 10 & 13.4 & 85.9 & 4.5 & $5.08 \mathrm{E}-02$ & \\
\hline $20 \mathrm{R}-3,4-6$ & 251.44 & 251.46 & $\mathrm{AF}$ & & $7-60$ & 11 & -11.0 & 143.7 & 1.4 & $4.69 \mathrm{E}-02$ & 5.5 \\
\hline $21 \mathrm{R}-1,35-37$ & 258.65 & 258.67 & TH & $325-575$ & & 11 & 25.1 & -77.0 & 3.0 & $4.63 \mathrm{E}-02$ & \\
\hline $21 \mathrm{R}-2,67-69$ & 260.47 & 260.49 & $\mathrm{AF}$ & & $7-80$ & 12 & 7.9 & -59.0 & 1.1 & $4.43 \mathrm{E}-02$ & 6.1 \\
\hline $21 \mathrm{R}-3,48-50$ & 261.71 & 261.73 & $\mathrm{TH}$ & $250-575$ & & 13 & 18.6 & 79.4 & 3.5 & $3.70 \mathrm{E}-02$ & \\
\hline 22R-2, 97-99 & 269.84 & 269.86 & AF & & $12-100$ & 11 & -0.3 & -33.9 & 1.9 & $2.12 \mathrm{E}-02$ & 5.8 \\
\hline $22 \mathrm{R}-3,113-115$ & 271.30 & 271.32 & $\mathrm{TH}$ & $150-525$ & & 13 & 22.8 & 145.6 & 3.3 & $1.93 \mathrm{E}-02$ & \\
\hline $22 \mathrm{R}-5,67-69$ & 273.65 & 273.67 & $\mathrm{TH}$ & $325-575$ & & 11 & 36.6 & 162.5 & 23.7 & $2.61 \mathrm{E}-02$ & \\
\hline $23 \mathrm{R}-1,78-80$ & 278.18 & 278.20 & $\mathrm{AF}$ & & $15-80$ & 9 & 0.4 & -41.1 & 2.1 & $3.21 \mathrm{E}-02$ & 4.6 \\
\hline $23 \mathrm{R}-2,49-51$ & 279.31 & 279.33 & $\mathrm{TH}$ & $425-575$ & & 7 & 3.6 & -97.1 & 3.8 & $2.78 \mathrm{E}-02$ & \\
\hline 23R-4, 92-94 & 282.60 & 282.62 & $\mathrm{AF}$ & & $10-100$ & 12 & -2.5 & 88.3 & 3.3 & $2.35 \mathrm{E}-02$ & 10.0 \\
\hline 24R-1, 109-111 & 288.09 & 288.11 & $\mathrm{TH}$ & $150-550$ & & 14 & -4.1 & -161.0 & 1.7 & $1.14 \mathrm{E}-02$ & \\
\hline $24 \mathrm{R}-3,31-33$ & 290.18 & 290.20 & $\mathrm{AF}$ & & $12-80$ & 10 & 3.8 & -155.4 & 1.0 & $1.66 \mathrm{E}-02$ & 6.2 \\
\hline $25 \mathrm{R}-1,24-26$ & 296.94 & 296.96 & $\mathrm{TH}$ & $325-550$ & & 10 & -1.2 & -138.0 & 2.1 & $1.57 \mathrm{E}-02$ & \\
\hline 25R-2, 119-121 & 299.39 & 299.41 & $\mathrm{AF}$ & & $12-80$ & 10 & -12.0 & 157.2 & 1.1 & 1.57E-02 & 10.4 \\
\hline $25 \mathrm{R}-4,71-73$ & 301.75 & 301.77 & $\mathrm{TH}$ & $150-550$ & & 14 & 4.9 & 144.9 & 2.6 & $1.40 \mathrm{E}-02$ & \\
\hline $25 R-5,57-59$ & 302.88 & 302.90 & $\mathrm{AF}$ & & $10-80$ & 11 & -7.5 & 170.6 & 0.8 & $1.50 \mathrm{E}-02$ & 10.8 \\
\hline $25 \mathrm{R}-7,13-15$ & 304.92 & 304.94 & $\mathrm{TH}$ & $150-550$ & & 14 & -1.0 & 166.0 & 1.6 & $1.30 \mathrm{E}-02$ & \\
\hline $26 \mathrm{R}-1,78-80$ & 306.98 & 307.00 & AF & & $10-80$ & 10 & -3.7 & 19.0 & 1.2 & $1.77 \mathrm{E}-02$ & 13.5 \\
\hline $26 \mathrm{R}-4,27-29$ & 310.54 & 310.56 & $\mathrm{TH}$ & $150-550$ & & 14 & 4.7 & 99.2 & 1.9 & $1.99 \mathrm{E}-02$ & \\
\hline $26 \mathrm{R}-8,11-13$ & 315.40 & 315.42 & $\mathrm{TH}$ & $150-550$ & & 14 & 4.2 & 42.7 & 3.3 & $2.12 \mathrm{E}-02$ & \\
\hline
\end{tabular}

Notes: For all samples, principal component analysis (PCA) is anchored to origin. $N=$ number of points used for $P C A, M A D=$ maximum angular deviation (Kirshvink, 1980), NRM $\chi=$ bulk susceptibility of natural remanent magnetization (NRM), MDF = median destructive field. $\mathrm{TH}=$ thermal demagnetization, $\mathrm{AF}=$ alternating-field demagnetization. 